\title{
Coal Liquefaction Process Streams Characterization And Evaluation
}

Quarterly Technical Progress Report October 1 Through December 31, 1989

G. A. Robbins, R. A. Winschel, and F. P. Burke

October 1990
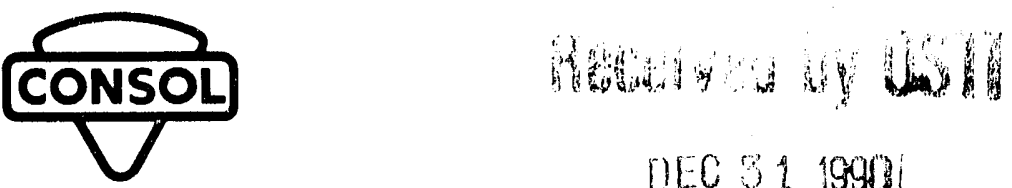

DIEC 811999

Consolidation Coal Company

Research and Development Department $400 \mathrm{C}$ Brownsville Road

Library, PA 15129

Prepared for the

United States Department of Encrgy

Under Contract No. DE-ACi22-89PC89883 
Nivit 4 isgo

\section{NOTICE}

This report wa'; prepared as an account of work sponsored by an agency of the United States Government. Neither the United States nor any agency thereof, nor any of their employees, makes any warranty, expressed or implied, or assumes any legal liability or responsibility for any third party's use or the results of such use of any information, apparatus, product or process disclosed in this report, or represents that its use by such third party would not infringe privately owned rights. 
TABLE OF CONTENTS

$\begin{array}{lr}\text { INTRODUCTION } & 1 \\ \text { Overview } & 1 \\ \text { Contract Objectives } & 2 \\ \text { Contract Activities - This Period } & 3 \\ & \\ \text { RESULTS AND DISCUSSION } & 5 \\ \text { Process Oil Analysis - Wilsonville Run 258 } & 5 \\ \text { Summary } & 5 \\ \text { Wilsonville Run 258 - Run Overview } & 7 \\ \text { Abbreviated History of Wilsonville Run 258 } & 8 \\ \text { Sample Descriptions } & 11 \\ \text { Analyses } & 12 \\ \text { Coal and Process Oil Properties } & 13 \\ \text { Effect of Resid on Donor Solvent Quality } & 17 \\ 8500^{\circ} \text { Ft Resid Conversion and Kinetics } & 19 \\ \text { Effect of Operating Variables on Process 0il Charac- } & \\ \text { teristics } & 22 \\ \text { Feed Coal } & 23 \\ \text { First-Stage Temperature } & 23 \\ \text { Cocond-Stage Temperature } & 24 \\ \text { Catalyst Age } & 25 \\ \text { Comparison of Wilsonville Runs 25l-II and 258 Process } & 25 \\ \text { Oil Characteristics } & 26 \\ & 29 \\ \text { EXPERIMENTAL } & 30 \\ \text { REFERENCES } & \end{array}$

\section{Table}

\section{LIST OF TABLES}

\begin{tabular}{|c|c|}
\hline & $\begin{array}{l}\text { Operating Conditions - Wilsonville Run } 258 \\
\text { Conditions and Yields - Material Balance Periods - } \\
\text { Wilsonville Run } 258\end{array}$ \\
\hline & $\begin{array}{l}\text { Analyses of Subbituminous Feed Coals - Wilsonville } \\
\text { Run } 258\end{array}$ \\
\hline & $\begin{array}{l}\text { Component Distribution of V-131B Samples - Wilson- } \\
\text { ville Run } 258\end{array}$ \\
\hline & $\begin{array}{l}\text { Component Distribution of V-1067 Samples - Wilsor - } \\
\text { ville Run } 258\end{array}$ \\
\hline & $\begin{array}{l}\text { Component Distribution of R-1235 Samples - Wilson- } \\
\text { ville Run } 258\end{array}$ \\
\hline & $\begin{array}{l}\text { Solubility Fractionation of V-131B Samples - Wilson- } \\
\text { ville Run } 258\end{array}$ \\
\hline & $\begin{array}{l}\text { Solubility Fractionation of V-1067 Samples - Wilson- } \\
\text { ville Run } 258\end{array}$ \\
\hline & Solubility Fractionation of R-1235 Samples - Wilson- \\
\hline
\end{tabular}

Page 
$\underline{\text { Table }}$

\section{LIST OF TABLES (Continued)}

10 Proton Distribution of $V-1318$ Whole Samples Wilsonville Run 258

11 Proton Distribution of V-1067 Whole Samples Wilsonville Run 258

12 Proton Distribution of R-1235 Whole Samples Wilsonville Run 258

13 Proton Distribution of V-131B Distillate Samples Wilsonville Run 258

14 Proton Distribution of V-1067 Distillate Samples Wilsonville Run 258

Proton Distribution of R-1235 Distillate Samples Wilsonville Run 258

16 Proton Distribution of V-131B Resid Samples Wilsonville Run 258

17 Proton Distribution of V-1067 Resid Samples Wil sonville Run 258

Proton Distribution of R-1235 Resid Samples Wilsonville Run 258

Phenol Concentration by

Microautoclave Test Results - Wilsonville Run 258

Conversion of Resid Components - Wilsonville Run 258

$850^{\circ} \mathrm{Ft}$ Conversion and Kinetics - Wilsonville Run 258

Comparison of Wilsonville Runs 251-II and 258 Operating Conditions

Pr, cess 011 Characteristics, Conversions and Kinetic Constants

42

43

44

45

46

47

48

49

50

51

52

53

54

55

56

\section{LIST OF FIGURES}

Fiqure

Simplified CC-ITSL Process Diagram for Wilsonville Run 258

Page

Partial CC.ITSL Process Diagram for Wilsonville Run 258 Showing Major Distillate Streams

Companent Distribution of Whole $V-131 B$ 0ils from Wilsonville Run 258

Component Distribution of Whole $\mathrm{V}-10670 i 1 \mathrm{~s}$ from Wilsonville Run 258

Component Distribution of Whole R-1235 0 ils from Wilsonville Run 258

Solubility Fractionation of $V-131 B$ THF-Soluble $850^{\circ} \mathrm{F}+$ Resid Samples from Wilsonville Run 258

Solubility Fractionation of V-1067 THF-Soluble $850^{\circ} \mathrm{F}+$ Resid Samples from Wilsonville Run 258

Resid Distribution of R-1235 THF-Soluble $850^{\circ} \mathrm{Ft}$ Resid Samples from Wilsonville Run 258

Proton Distribution of V-131B Distillate and THFSoluble Resid Samples ( $850^{\circ} \mathrm{F}+$ Cutpoint) from Wilsonville Run 258 
Proton Distribution of V-1067 Distillate and THF-

Page Soluble Resid Samples (850 $\mathrm{F}+$ Cutpoint) from Wilsonville Run 258

11 Proton Distribution of R-1235 Distillate and THFSoluble Resid Samples $\left(850^{\circ} \mathrm{F}+\right.$ Cutpoint) from Wilsonville Run 258

Phenolic - $\mathrm{OH}$ Concentrations of Distillate and THFSoluble Resid Samples (850 $\mathrm{F}^{+}$Cutpoint) from Wilsonville Run 258

13 Microautoclave Solvent Quality Assays of $850^{\circ} \mathrm{F}$ Distillate Samples from Wilsonville Run 258

14 First-Stage and Total $850^{\circ} \mathrm{Ft}$ and Coal + IOM for Wilsonville Run 258

15 Second-Stage $850^{\circ} \mathrm{F}+$ Component Conversions for Wilsonville Run 258

16 Kinetic Rate Constants for First- and Second-Stage $850^{\circ} \mathrm{Ft}$ Conversions for Wilsonville Run 258

$17850^{\circ} \mathrm{Ft}$ Conversion Activities for First and Second Stages in Wilsonville Run 258

Catalyst Deactivation Plot for Wilsonville Run 258

69

70

Appendix

\section{APPENDICES}

1 Applications of Coal Liquefaction Solvent Quality

2 The Evolution of Process $0 i 1$ Characteristics in

Page Two-Stage Coal Liquefaction Process Development 
COAL LIQUEFACTION PROCESS STREAMS CHARACTERIZATION AND EVALUATION QUARTERLY TECHNICAL PROGRESS REPORT, 10/1-12/31/89

\section{ABSTRACT}

This is the first quarterly Technical Progress Report under DOE Contract DE-AC22-89PC89883. Two major topics are reported hele: 1) Feed coals and process oils from Wilsonville Run 258 were analyzed to provide information on process performance. Run 258 was operated in the thermal/catalytic Close-Coupled Integrated Two-Stage Liquefaction (CC-ITSL) mode with ash recycle. The subbituminous feed coals were from the Spring Creek Mine (Anderson and Dietz seams) and from the Black Thunder Mine (Wyodak and Anderson seams). She11 324 catalyst was used in the second stage. 2) The abstract of a paper presented at Frontiers in Coal Science and Technology Conference held in Fukuoka, Japan on October 29-31, 1989, and a paper presented at the AIST-ANRE-NEDO/DOE-PETC Joint Technical Meeting on Coal Liquefaction in Tokyo, Japan, October 31 through November 2, 1989, are appended to this report. 


\section{Section 1 \\ INTRODUCTION}

This is the the Technical Progress Report for the first quarter of activities under DOE Contract No. DE-AC22-89PC89883. It covers the period October 1, 1989, through December 31, 1989.

\section{OVERVIEW}

Direct coal liquefaction is a complicated chemical process. Recent advances in the technology, which significantly reduced the product costs, have come about through an improved fundamentai understanding of liquefaction chemistry. Further improvements are possible, and will depend on continued advances in our knowledge of process chemistry. Supplying this knowledge requires the use of a variety of the tools of analytical chemistry applied to the appropriate samples, and interpretation of the analytical data in context to process development.

The R\&D Department of Consolidation Coal Compary (Consol R\&D) is conducting a three-year project to characterize process and product streams from direct coal liquefaction process development programs sponsored by the Department of Energy. In this project, Consol R\&D will obtain samples from current process development activities in coal liquefaction and coal-oil coprocessing, and characterize them using established analytical techniques. In addition, selected samples will be characterized by other analytical techniques to evaluate their potential for aiding process development. These analyses and interpretation of the results in relation to process operations will be provided by a subcontracted project team.

In addition to samples from current process development programs, Consol R\&D maintains a bank of coal liquids samples from the SRC-I, H-Coal, ITSL (Lummus and Wilsonville) and HRI-CTSL coal liquefaction programs, and the Lummus, HRI and UOP coprocessing development 
programs. These samples, which represent important stages in the recent development of coal liquefaction technology, also will be used in the analytical program.

\section{CONTRACT OBJECTIVES}

Consol R\&D is conducting a three-year program to characterize process and product streams from direct coal liquefaction process development projects. The program objectives are two-fold: 1) to obtain and provide appropriate samples of coal liquids for the evaluation of analytical methodology, and 2) to support ongoing DOE-sponsored coal liquefaction process development efforts. The two broad objectives have considerable overlap and together serve to provide a bridge between process development and analytical chemistry.

More specifically, the first objective is to identify, collect and disburse appropriate samples of coal liquids for analysis by techniques that hold promise, but are not fully demonstrated, for use in liquefaction process development efforts. Samples will be chosen from ongoing DOE-funded liquefaction and coprocessing projects and from Consol's collection of coal liquids produced during the past ten years. Samples will be chosen based on their relevance to process development programs, and will be well-documented in terms of feedstocks, sampling location, time and operating conditions. The samples chosen will be sufficient to judge the applicability of the analytical methods being evaluated. These process oils will be analyzed by Conso? R\&D in a base characterization program using techniques established in previous consol research. Selected samples also will be provided to project team participants (as subcontractors), other researchers active in the analysis of coal liquids, who will characterize them using a range of methods beyond those used in the base program. Subcontracts to approximately 10 to 15 organizations that have specialized analytical capabilities will be a major aspect of this work. Individual analytical specialists from the subcontractors will take a major role in interpreting their own results in 
context to the liquefaction process, and not merely provide data. This portion of the program will evaluate the utility of promising analytical techniques for providing useful information for coal liquefaction process development, and will apply those results to ongoing development efforts. This evaluation will be based on the usefulness of an analytical method in process monitoring, to obtain specific chemical information, and as judged by precision and accuracy.

The second objective is to support the process developers. This will include support in the form of providing results and interpretation of data obtained with the analytical techniques being assessed. However, more directly, appropriate process oils will be characterized in the base program by a variety of standard techniques that have proven relevance to development efforts. The results from these more routine analyses will aid plant operations and planning. Also, these results will provide the data needed to select appropriate samples for the non-routine techniques and provide a set of data for correlations with the results of the more exploratory techniques.

\section{CONTRACT ACTIVITIES - THIS PERIOD}

Contract activities for this quarter are listed below. Each topic is summarized and discussed in detail under a separate heading in Section 2, Discussion. Because each topic is summarized, when appropriate, in the corresponding section of the Discussion, no overall summary section is provided in this report.

- Two feed coals and 39 process oils from Wilsonville Run 258 were analyzed to provide information on process performance. Run 258 was operated in the thermal/catalytic Close-Coupled Integrated Two-Stage Liquefaction (CC-ITSL) mode with ash recycle. The subbituminous feed coals were from the Spring Creek Mine (Anderson and Dietz seams) and from the Black Thunder Mine 
(Wyodak and Anderson seams). Shell 324 catalyst was used in the second stage.

- Various coal samples related to Wilsonville Run 259 were analyzed for chemical and petrographic composition. These results will be given in a future report, which covers a11 of Run 259.

- A paper, entitled "Process and Recycle 0ils in Two-Stage Coal Liquefaction", was presented by F. P. Burke at the 1989 International Conference on Coal Science, Tokyo, Japan, in october 1989. The manuscript appeared in a previous report (1).

- A paper, entitled "Applications of Coal Liquefaction Solvent Quality Measurements", was presented by F. P. Burke at Frontiers in Coal Science and Technology, held in Fukuoka, Japan, on October 29-31, 1989. The abstract appears as Appendix 1 of this report.

- A paper, entitled "The Evolution of Process 0 il Characteristics in Two-Stage Coal Liquefaction Process Development", was presented by F. P. Burke at the AIST-ANRE-NEDO/DOE-PETC Joint Technical Meeting on Coal Liquefaction in Tokyo, Japan, October 31 through November 2, 1989. This paper appears as Appendix 2 of this report.

- A paper, entitled "Recycle 0ils from Fluid Coking of Coal Liquefaction Bottoms", was presented by R. A. Winschel at the 1989 Fall Information Transfer Session of The Pennsylvania State University Cooperative Program in Coal Research in State College, Pennsylvania, November 20-21, 1989. The paper appeared in a previous report (2). 


\section{Section 2 \\ RESULTS AND DISCUSSION}

\section{P'ROCESS OIL ANALYSIS - WILSONVILLE RUN 258}

\section{SUMMARY}

Consol analyzed two feed coals and 39 process oils from Wilsonville Run 258 which was operated in the thermal/catalytic close-Coupled Integrated Two-Stage Liquefaction (CC-ITSL) mode with ash recycle. The subbituminous feed coals were from the Spring Creek Mine (Anderson and Dietz seams) and from the Black Thunder Mine (Wyodak and Anderson seams) and Shell 324 Shell catalyst was used in the second stage. The major resu'ts from Consol's analyses are summarized below.

- Few differences were seen between properties of process $0 i 1 \mathrm{~s}$ produced at identical conditions from the two different feed coals. Resids produced from Black Thunder coal contained slightly higher $0 i 1$ and preasphaltene concentrations and slightly lower asphaltene concentrations than those produced from Spring creek coal.

- Relative to oils typically produced at Wilsoriville, process oils produced during Run 258 were high in hydrogen aromaticity, in preasphaltene concentration, and in phenolic $-\mathrm{OH}$ concentration. This apparently resulted from high coal feed rates and firststage reactor temperatures. Solvent quality was high throughout the run.

- The addition of hydrotreated (second stage) and thermal (first stage) resids from periods $D$ and $H$ to their corresponding distillates had a significant detrimental effect on donor solvent quality, as determined by a special set of microautoclave tests. This behavior is in contrast to that observed in runs made prior to the standard use of ash recycle, in which hydrogenated resid 
always improved solvent quality. Every run since 251 has been made with ash recycle and has shown at least a few periods in which the whole hydrotreated oils gave lower coal conversion in microautoclave tests than their corresponding distillates. This has generally been attributed to scatter in the test results, resulting from high solids concentrations in the whole oils. In the present case, the detrimental effect of the hydrotreated resids was verified by additional tests made without solids present.

- Compared to Run 251-II, the only other thermal/catalytic CC-ITSL run with subbituminous coal (Clovis Point Mine, Wyodak seam), oils produced during Run 258 were higher in hydrogen aromaticity, resid preasphaltene concentrations, and phenolic $-\mathrm{OH}$ concentrations. First-stage and total $850^{\circ} \mathrm{Ft}$ conversions were lower in Run 258 than in Run 251-II.

- Compared to Run 251-II, the only other thermal/catalytic CC-ITSL run with subbituminous coal (Clovis Point Mine, Wyodak seam), oils produced during Run 258 were higher in hydrogen aromaticity, resid preasphaltene concentrations, and phenolic $-\mathrm{OH}$ concentrations. First-stage and total $850^{\circ} \mathrm{Ft}$ conversions were lower in Run 258 than in Run 251-II, as were first-stage rate constants and activities for $850^{\circ} \mathrm{F}+$ conversion. In the second stage, the rate constants for $850^{\circ} \mathrm{F}+$ conversion followed the trend $251-I I(A-D)=258(A-G)<258(H-M)$ and the activities for $850^{\circ} \mathrm{Ft}$ conversion followed the trend $258(A-G) \leq 251-I I(A-D)<258(H-M)$. Differences in oil characteristics between the two runs are attributable to the higher space velocity, catalyst age, reactor temperatures, and lower reactor volume in use during Run 258.

- Increases in hydrotreater temperature from 760 to $790^{\circ} \mathrm{F}$ (comparing period $C$ with $D$ and period $L$ with $M$ ) had virtually no effect on process oil properties. The increases in teinperature were 
accompanied by slight increases. in second-stage and total $850^{\circ} \mathrm{Ft}$ conversions.

- Contrary to typical observations, a decrease in the coal feed rate from $245 \mathrm{MF} \mathrm{lb} / \mathrm{hr}$ in period $\mathrm{D}$ to $195 \mathrm{MF} \mathrm{lb} / \mathrm{hr}$ in period $\mathrm{E}$ was accompanied by increases in hydrogen aromaticity and phenolic $-\mathrm{OH}$ concentration in the process oils, and by slight decreases in the $850^{\circ} \mathrm{Ft}$ conversions in both reactor stages. This appears to coincide with a loss in catalyst activity reported by Wilsonville.

\section{WILSONVILLE RUN 258 - RUN OVERYIEW}

Consol analyzed two feed coals and 39 process oils from Wilsonville Run 258 which was operated with subbituminous coal and 1/16-incin extrudate Shell 324 ( $\mathrm{Ni} / \mathrm{Mo}_{0}$ on $\mathrm{Al}_{2} \mathrm{O}_{3}$ ) catalyst. Run 258 was operated from May 19 through November 8, 1989, in the thermal/catalytic Close-Coupled Integrated iwo-Stage Liquefaction (CC-ITSL) mode with ash recycle. The coal fed from May 19 through August 26 was from the Spring Creek Coal Company's Spring Creek Mine in Big Horn County, Montana, (Anderson and Dietz seams). Coal from the Thunder Basin Coal Company's Black Thunder Mine in Campbell County, Wyoming, (Wyodak and Anderson seams) was fed from September 14 through November 8 . The interstage separator was in use throughout the run. Although the first stage was operated thermally, a disposable $\mathrm{Fe}_{2} \mathrm{O}_{3}$ catalyst was added at a rate of about 2 to $3 \mathrm{wt} \%$ of the MF coal, with sufficient dimethyldisulfide (DMDS) added to maintain sulfidation of the disposable catalyst. Catalyst addition/withdrawal in the second stage was used during most of the run, although fresh catalyst was charged and batch-deactivated later in the run. The major operating variables for Run 258 were coal (Spring Creek vs Black Thunder), coal feed rate (ca. 190-290 MF 1b/hr), first-stage temperature (ca. 825-865 $\mathrm{F}$ ), and second-stage temperature (ca, 740-790 $\mathrm{F}$ ). Wilsonville's T-102 distillation tower became inoperative one month into the run, necessitating a modification in the distillate product flow scheme 
throughout the emainder of the run. Throughout Run 258, Wilsonville used $50 \%$ reactor volume takeoff points in both the thermal and catalytic stages.

The original Run 258 objectives were: 1) to screen a low-ash subbituminous coal (Spring creek) at high space ve?ocities in the thermal/catalytic CC-ITSL mode with variation in reactor temperatures and space velocities, 2) to perform a short test with Black Thunder coal to compare with Spring Creek coal, and 3) to evaluate the cata7ytic/catalytic CC-ITSL mode with the preferred coal. As the run progressed, the third objective was replaced by a new one: to jotain a batcn deactivation curve for 1/16-inch Shell 324 catalyst using Black Thunder coal. This new objective resulted from poor resid conversion when Spring Creek coal was fed, which was attributed to deactivation of the catalyst. Spring Creek coal contains a high sodium content and the spent catalyst was observed to be low in activity and high in sodium and iron contents. The carbon content of the catalyst showed a significant increase starting with period $E$ and continuing through period $\mathrm{J}$, at which point the aged catalyst was replaced with fresh catalyst.

Operating conditions ( 3 ) for those periods from which we were supplied samples appear in Table 1. Operating conditions and yields ( 3 ) for material balance periods appear in Table 2. A simplified flow scheme $(3,4)$ of the Wilsonville plant, as configured for Run 258, appears in Figure 1. More detail on that part of the plant involving the major distillate streams is shown in Figure 2.

\section{ABBREVIATED HISTGRYY OF WILSONVILLE RUN 258}

This section is paraphrased from Wilsonville technical review meeting handouts ( $(3)$. Run 258 began on May 19, 1989, in the thermal/catalytic CC-ITSL mode feeding Spring Creek subbituminous coal. The first-stage (thermal) reactor was $\mathrm{R}-1235$ and the second-stage (catalytic) reactor was $R-1236$. Both reactors were configured to use half of the avail- 
able volume. The interstage separator was used throughout the run. Disposable $\mathrm{Fe}_{2} \mathrm{O}_{3}$ was mixed with the coal slurry prior to feeding it to the first stage. The second-stage reactor was charged with $2251 \mathrm{~b}$ (ivet) Shel1 324 1/16-inch ("i/Mo) catalyst which was used previously in Run $\angle 55$ with Texas lignite (initial age ca. 3330 lb (resid $+\mathrm{CI}$ )/ $1 \mathrm{~b}$ cat or 1869 lb MF coal/lb cat). Dimethyldisulfide (DMDS) was injected into both reactors to provide adequate sulfidation of the disposable and supported catalysts. The start-up 011 was from Run 257, which was made with Illinois 6 coal. Start-up conditions werf: $250 \mathrm{Mi} \mathrm{lb} / \mathrm{hr}$ coal feed rate, $40 \mathrm{wt} \%$ resid in the recycle solvent, 25 wt \% cresol insolubles (CI) in the recycle solvent, solvent/coal ratio of 2.3 , iron oxide addition rate of $4.0 \mathrm{wt} \%$ of MF coal, first-stage DMDS addition rate of 2.4 wt $\%$ MF coal, $840 \%$ first-stage reaction temperature, second-stage catalyst addition/withdrawal rate of $1.5 \mathrm{lb} /$ ton MF coal, second-stage DMDS addition rate of $2 \mathrm{lb} / \mathrm{hr}$, and $740^{\circ} \mathrm{F}$ secondstage reaction temperature. On May 21 , the unit went down due to a power outage and ebullating pump problems. The plant was restarted on May 24 , and $13.1 \mathrm{lb}$ of wet catalyst was added to bring the loading to the target of $170 \mathrm{lb}$ (dry). The plant went down again the next day with an ebullating pump problem. All the catalyst was withdrawn on May 25, and replaced on June 10 after the pump repairs were complete.

When the unit was restarted on June 11, the first-stage iron oxide and DMDS addition rates were reduced to 2 and $1.2 \mathrm{wt} \%$ MF coal, respectively. The CI content of the recycle solvent was also reduced to 20 wt $\%$, because of problems pumping the coal slurry with $25 \% \mathrm{CI}$. On June $13,13.5 \mathrm{lb}$ (wet) catalyst was added to bring the loading to 160 $1 \mathrm{~b}$ (dry), and on June 14 another $13.1 \mathrm{lb}$ (wet) catalyst was added to bring the loading to $170 \mathrm{lb}$ (dry). On June 20, the T-102 distillation column went down for the remainder of the run (an unsuccessful restart attempt was made on July 7). Several flow changes were made and the run continued uninterrupted. The flow changes were: $V-1072$ was sent to V-1074, V-1078 was sent to T-105, and V-1074 (instead of P-171, the T-102 tray 3 distillate) was used for withdrawal tube flush. The V-1074 was too heavy for withdrawal tube flush and withdrawal tube 
plugging took place. T-105 bottoms was used for withdrawal tube flush for the remainder of the run. Extra catalyst addition/withdrawal took place on June 20 and June 22 to adjust the catalyst age to the target value. Due to a high $C_{1}-C_{3}$ gas yield and low resid yield, on June 23 the first-stage temperature was lowered from 840 to $825^{\circ} \mathrm{F}$ and the second-stage temperature was raised from 740 to $760^{\circ} \mathrm{F}$. Catalyst crushed by clearing the plugging in the withdrawal tube was removed on June 23 (30 $1 \mathrm{~b}$ dry) and June 24 (11.4 $\mathrm{lb}$ dry), and replaced by 41.4 1b (dry) fresh catalyst on June 24 . On June 26, plugging took place again and $19.8 \mathrm{lb}$ crushed catalyst was withdrawn. Un June 27 , the DMDS injection port was removed from the withdrawal tube and relocated to eliminate the plugging problems. The first-stage temperature was increased from 825 to $840^{\circ} \mathrm{F}$ on June 29 , and the second-stage temperature was increased from 760 to $790^{\circ} \mathrm{F}$ on July 8 . Both changes were made to increase coal conversion.

During an outage from July 16-29, an ebullation pump was repaired, and the V-1258 interstage separator and connecting lines with the firststage reactor were cleaned of solids which built up inside. Catalyst was removed from the second-stage reactor from July 16-27 for the repairs. On August 2, $15.8 \mathrm{lb}$ catalyst was added to the second-stage reactor to bring the catalyst up to the pre-shutdown charge. On August 4, the coal feed rate was decreased from 230 to $200 \mathrm{MF} 1 \mathrm{~b} / \mathrm{hr}$. While at the lower coal feed rate, a limit was set on the second-stage preheater outlet temperature so that resid would not be exposed to high temperatures. For this reason, the average reactor temperature was about $2^{\circ} \mathrm{F}$ below target during operation at the low coal feed rate. On August 11, the cresol insolubles (CI) concentration in the recycle solvent was increased from 20 to $25 \mathrm{wt} \%$. After August 13, the target second-stage temperature $\left(790^{\circ} \mathrm{F}\right)$ could not be maintained due to the preheater setpoint, so on August 16 the target temperature was lowered to $760^{\circ} \mathrm{F}$. On August 21 , the $\mathrm{Fe}_{2} \mathrm{O}_{3}$ addition rate was increased from 2 to 3 wt \% MF coal. On August 26, a planned shutdowr was made to repair ebullation pumps and to clean the lines in the reactor section. 
Before the shutdown, a pressure buildup between the $R-1235$ reactor and V-1258 interstage separator had been taking place.

The shutdown continued until September 14, when Run 258 was restarted. The run resumed with a higher coal feed rate of $250 \mathrm{MF} 1 \mathrm{~b} / \mathrm{hr}$ (began feeding $\mathrm{Black}$ Thunder coal), a lower $\mathrm{Fe}_{2} \mathrm{O}_{3}$ addition rate of 2 wt \% MF coal, a lower CI concentration in the recycle solvent of $20 \mathrm{wt} \%$, and a higher second-stage temperature of $790^{\circ} \mathrm{F}$. Catalyst addition/withdrawal was suspended until September 19 so that the target equilibrium catalyst age could be reached. On September 15, 19.6 ib of catalyst was withdrawn from the second-stage reactor, to bring the catalyst loading to the target value (170 1b dry). On September 23-24, the plant experienced a loss in reaction (evident by lower first stage exotherm), which was attributed to water contamination of the DMDS being injected or to failure to inject it. On 0ctober 6, the first. stage temperature was increased from 852 to $864^{\circ} \mathrm{F}$. On October 11 , the plant was shut down for repairs and to replace the aged second-stage catalyst with 250 1b fresh She 11324 catalyst.

After catalyst change-out, the run was restarted on 0ctober 16 with reactor temperatures of $852^{\circ} \mathrm{F} / 760^{\circ} \mathrm{F}$ and a coal feed rate of $300 \mathrm{MF}$ 1b/hr (again feeding Black Thunder coal). Batch deactivation of the catalyst was used for this portion of the run. On November 2 , the second-stage temperature was increased from 760 to $790^{\circ} \mathrm{F}$ and catalyst addition/withdrawal commenced at $3 \mathrm{lb} / \mathrm{ton}$. From November 3 on, middle distillate from V-178 (typically 40\% 650 $\mathrm{F}^{-}$) was used to make up a deficiency in V-1074 heavy solvent inventory (typically 15\% $650^{\circ} \mathrm{F}-$, used for recycle). The run ended on November 8,1989 . As in the earlier parts of the run, solids accumulated in the interstage separator from 0ctober 16 to the end of the run.

\section{SAMPLE DESCRIPTIONS}

Consol received two feed coal samples and 39 process oil samples from Run 258. The coals received were spring creek coal (pile sample, 
Wilsonville sample number 95345, sampled May 4, 1989, at 12:00, received June 19,1989 ) and Black Thunder coal (tote bin sample number TB10111, Wilsonville sample number 99460, sampled September 21, 1989, at 23:00, received November 28, 1989). The process 0ils consisted of a recycle oil (V-131B) sample, an interstage oil (R-1235 HP) sample, and a product 011 ( $V-1067)$ sample from each of the thirteen material balance periods A through $M . \quad V-1067$ is the second-stage flashed bottoms product. Although the interstage samples were labelled R-1235 HP, they will be referred to as R-1235 samples throughout this report. The HP suffix designates that these samples were taken after the high-pressure flash (interstage separator in operation).

\section{ANALYSES}

Proton distributions were obtained by ${ }^{1 H}$-NMR for each of the $\mathrm{V}-131 \mathrm{~B}$, interstage and $V-1067$ whole samples (Tables 10-12). All the whole samples were tested in the microautoclave at the modified equilibrium conditions (Table 20). Prior experience has shown that the microautoclave results show high variability when the samples have high solids concentrations, as was the case in Run 258 . The whole samples were distilled (Tables $4-6$ ) to $320^{\circ} \mathrm{C}$ pot $/ 270^{\circ} \mathrm{C}$ column $/ 5$ torr $\left(850^{\circ} \mathrm{F} / \mathrm{atm}\right)$. Each $850^{\circ} \mathrm{F}+$ resid was analyzed by solubility fractionation (Tables 7-9), ${ }^{1} \mathrm{H}-\mathrm{NMR}$ (Tables 16-18) and FTiR for phenolic -OH content (Table 19). Each $850^{\circ} \mathrm{F}$ - distillate was analyzed by ${ }^{1} \mathrm{H}$-NMR (Tables 13-15) and FTIR (Table 19). Microautoclave tests were made at the modified equilibrium conditions with each $850^{\circ} \mathrm{F}^{-}$distillate (Table 20). Details of the sample work-up and analytical procedures have been presented elsewhere $(\underline{5,6})$. All samples for proton distribution by NMR were dissolved in $99.96 \%$ deuterated pyridine (whole or resid samples) or in $\mathrm{CDCl}_{3}$ (distillate samples) and integrated electronically. Selected samples were used to determine response factors for flame ionization detection of solubility fractions. A different set of response factors was used, depending on the feed coal used to produce the oil sample. 
COAL AND PROCESS OIL PROPERTIES

Chemical analyses of the Spring Creek Mine and Black Thunder Mine feed coals are given in Table 3. The Spring Creek coal has lower contents of moisture, volatile matter, ash, and oxygen (by difference). The Black Thunder coal has a lower carbon content and heating value. Both coals have high $\mathrm{CaU}$ contents. The $\mathrm{Na}_{2} \mathrm{O}$ coritent of Spring Creek coal $\left(4.55 \% \mathrm{Na}_{2} \mathrm{O}\right)$ is quite high. Spring Creek coal has a higher $\mathrm{Na}_{2} \mathrm{O}$ and a lower CaO content thar. Black Thunder coal. Wilsonville personnel found high levels of $\mathrm{Na}$ on spent catalyst samples from the Spring Creek portion of Run 258, and they suspected it to be 1argely responsible for poor catalyst performance with Spring creek coal. Because of this concern, they identified Black Thunder coal as the preferred feed for a future run, even though it gave slightly poorer performance in some respects $(\underline{3})$.

Properties of process 0ils from Run 258 are given in Tables 4 through 20 and presented graphically in Figures 3 through 13. The discussion is followed most easily by referring to the figures. Because of high variability, no general discussion of the whole sample microautoclave results will be given. However, results from selected whole samples are discussed in a later section. The compositions of the $V-131 \mathrm{~B}$, $V-1067$, and R-1235 whole oils (Figures 3-5, Tables 4-6) were fairly consistent throughout the run. The $V-131 \mathrm{~B}$ and $V-1067$ samples contained about $49 \% 850{ }^{\circ} \mathrm{F}$ resid, 30\% distillate, $10 \% 10 \mathrm{M}$ and $10 \%$ ash (higher ash and lower distillate during periods $F$ and $G$ ). The R-1235 samples contained about 1-2\% more resid, about 1-2\% more IOM and about $4 \%$ less distillate than the hydrotreated $0 i 1 s$. The elevated ash contents observed for periods $F$ and $G$ reflect operation with $25 \%$ cresol insolubles (CI) in those periods vs $20 \%$ for the rest of the run. The sum of IOM and ash contents measured by consol for each period agrees well with Wilsonville's target CI level in the (V-131B) recycle solvent. The relative concentrations of $I O M$ and ash measured by Consol in the $V-131 B$ streams appear to correspond to Wilsonville's overall coal conversions for the run (Table 2). Ash and IOM were at 
the same concentration in the $V-131 B$ oils (ca. 10\%) during periods $B$, $K, L$, and $M$ (Figure 3, Table 4), when the coal conversions were below $92 \% \operatorname{MAF}$ coal (88.3 to $91.2 \%$ ). For the remaining periods $A$ and $C$ through $J$, the $V-131 B$ ash concentration was higher than the IOM concentration (Figure 3, Table 4) and the plant coal conversions were higher than $92 \%$ MAF coal $(92.1$ to $95.0 \%)$. The coal conversion was greater than $94 \%$ during periods $E$ through $G$, when the highest $V-131 B$ ash concentrations were observed. Since Wilsonville determines coal conversion from an ash balance basis (relative ratio of IOM and ash), the Consol and Wilsonville results are seen to be in qualitative agreement.

Solubility fraciions of the THF-soluble portion of the $850^{\circ} \mathrm{F}+$ resids are shown in Figures 6 through 8 and given in Tables 7 through 9. In general, the oils (hexane soluble) contents of the resids from all three process streams decline slightly from period $A$ to $C$ or $D$, then increase to period $\mathrm{J}$ or $\mathrm{K}$, and then decline again slightly. This fluctuation occurs within a moderate range of about $9 \%$. The asphaltenes (hexane insolubles, benzene solubles) contents of the resids show a less consistent trend for the three streams, but a consistent decrease is noted from period $G$ to $H$ when the feed coal (and other variables) changed. The asphaltenes concentration of the resids is generally higher in periods $A$ through $G$ then in $H$ through $M$. Conversely, the preasphaltene (benzene insolubles, tetrahydrofuran (THF) solubles) concentration in the resids increased after period $G$. Besides the different feed coal, the latter half of the run used relatively higher coal feed rates and first-stage temperatures. The preasphaltenes concentrations in the resids appear to roughly follow the coal feed rate throughout the run. The change in feed coal may also be a factor, as will be discussed later.

Several interesting features are evident in the proton distributions of the process uils and their resid and distillate fractions (Figures 9-11, Tables 10-18). Hydrogen aromaticities of all whole oils (Tables 10-12), and their distillate and resid fractions 
(Figures 9-11, Tables 13-18) show the same trend: the aromaticities increase from periods $B$ through $E$, are constant through period $H$, then increase again from period $H$ to a maximum during period $J$, and then decline to a lower value for periods $K$ through $M$. It appears that this trend results primarily from changes in coal feed rate, firststage temperature and catalyst age. During period $\mathrm{J}$ when the aromaticity was highest, the coal feed rate and temperatures in both reactors were at their maximum values. The decreases in temperature (both reactors) and catalyst age (replacement by a fresh batch of catalyst) ongoing from period $\mathrm{J}$ to $\mathrm{K}$ were accompanied by a decrease in aromaticity. The aromaticity increased consistently from periods $C$ through $E$, in spite of an increase in the hydrotreater temperature $(C$ to $D)$ and a decrease in the coal feed rate ( $D$ to $E$ ). Both of these steps are expected to lower aromaticity (improve hydrogenation), based on Consol's past experience with Wilsonville process oils. Hrwever, Wilsonville reported a lower catalyst activity (1ab test) during period $D$ than in previous periods and an increase of about 3 sit $\%$ carbon on the catalyst in periods $E$ through $G$, relative to prior periods ( $(3)$. The carbon increase apparently resulted from an increase in the interstage heater temperature necessitated by the lower coal feed rate. The higher catalyst carbon content was accompanied by a lower second-stage reactor exotherm, indicating that less hydrogenation was taking place $(\underline{3})$. The aromaticity increases for periods $\mathrm{C}$ through $E$ are consistent with decreasing catalyst hydrogenation activity and appear to coincide with Wilsonville's reported loss in catalyst activity. The trend described above for aromaticity is oppositely mirrored by the paraffinic (alkyl beta plus gamma) hydrogens in the distillates from all three streams, the minimum being reached in period $\mathrm{J}$ (Figures 9-11, Tables 13-15). The hydroaromatic (cyclic beta) hydrogens in the distillates follow a trend similar to the paraffinic hydrogens, though the magnitude of change is much smaller.

Phenolic $-\mathrm{OH}$ concentrations of $\mathrm{V}-131 \mathrm{~B}$ distillates and resids were virtually identical to those of their V-1067 counterparts (Figure 12). 
The R-1235 distillates and resids were equivalent in phenolic - $\mathrm{OH}$ concentration, which were consistently higher than those of the hydrogenated resids. The concentrations of phenolic $-\mathrm{OH}$ in nearly all the samples were quite high. Except for the therma? interstage (R-1235) resids, which are fairly iypical, all the samples have phenolic $-\mathrm{OH}$ concentrations which are $0.2 \mathrm{meq} \mathrm{OH} / \mathrm{g}$ sample or more higher than observed in the last two thermal/catalytic Wilsonville runs with low rank coals (Run 251-II with Wyodak subbituminous and Run 255 with Martin Lake lignite). It appears that the higher coal feed rate used in Run 258 is a contributing factor to the higher phenolic $-\mathrm{OH}$ concentrations. Other contributing factors may include differences in catalyst activity and differences in the feed coals.

Phellolic $-\mathrm{OH}$ concentrations of all distillate and resid sai.ples increased to a maximum at period $G$, and then generally decreased to the end of the run (Figure 12, Table 19). Some of these changes do not fit expectations based on known changes in operating conditions. For example, the phenolic $-\mathrm{OH}$ concentrations of the hydrotreated distillates increased from periods $C$ through $E$, tracking the increase in the aromaticity. This suggests a loss in the deoxygenation ability of the catalyst in spite of operating changes which are expected to decrease phenolic $-\mathrm{OH}$ concentration. Like the aromaticity increase, this appears to coincide with Wilsonville's reported loss in catalyst activity. Past experience has indicated that the aromaticity and phenolic $-\mathrm{OH}$ frequently are correlated. For the hydrotreated resids, however, the lowered coal feed rate for period E did lower the phenolic $-O H$ concentration. Periods $F$ and $G$ showed even higher distillate and resid phenolic $-\mathrm{OH}$ concentrations, in spite of the low coal feed rate (same as in period E). However, the second-stage temperature was lower in periods $F$ and $G$ relative to $D$ and $E$, and thus higher phenolic $-\mathrm{OH}$ concentrations are expected in periods $F$ and $G$. Low catalyst age during periods $K, L$, and $M$ undoubtedly contributed to lower phenolic $-\mathrm{OH}$ concentrations in most of the samples at the end of the run. 
Distillate solvent quality, as determined by microautoclave assay, was good to excellent for the hydrotreated ( $V-131 B$ and $V-1067$ ) 0ils ar: fair for the thermal first-stage product (R-1235) oils (Figure 13, Table 20). The solvent quality of the hydrotreated distillates increased from about $83 \%$ conversion in period $B$ to a maximum of about $89 \%$ conversion in period $K$. The solvent quality of the hydrotreated distillates produced during period $K$ was excellent. Subbituminous coal Runs 246 and 249 also produced some distillates $(\underline{5})$ and whole oils $(\underline{5,7})$ which had excellent solvent quality. Consol's experience does not indicate why the hydrotreated distillates produced around period $K$ should be superior to the samples preceding them, such as in periods $B$ through $F$. However, the slightly elevated hydroaromatic (cyclic beta) hydrogen content and low phenolic - $\mathrm{OH}$ concentrations in those distillates during period $K$ may both be factors. It would appear that the high coal feed rates and high thermal first-stage temperatures may be factors, since period $I$ and $J$ hydrotreated distillates are also somewhat better than preceding distillates. Fresh catalyst may be a factor in the prominence of the period $k$ distillates. In contrast to the hydrotreated distillates, the interstage distillates stayed fairly constant, or perhaps declined slightly in solvent quality near the end of the run.

\section{EFFECT OF RESID ON DONOR SOLVENT QUALITY}

It is evident from the data in Table 20 that the whole oil samples gave lower MAF coal conversions than their distillate-only counterparts in microautoclave tests. However, this comparison is complicated by the high solids concentrations in the whole $011 \mathrm{~s} \quad 20 \%$ or more), which sometimes causes high scatter and unreliable results. To determine what role the resid played in the donor solvent quality of the oil samples in the absence of solids, selected solids-free resids were mixed with their corresponding distillates in their original proportions in the whole $0 i 1$ and tested in the microautoclave. Results are given in the table below. 
Sample

V-131B

Distillate

Whole (Solids-Free)

Whole (Incl. Solids)

$\mathrm{R}-1235$

Distillate

Whole (Solids-Free)

Whole (Incl. So? ids)

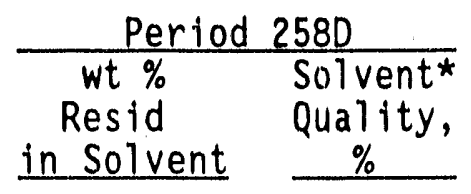

0.0

61.1

47.7

0.0

64.6

49.0
83.2

72.3

$72.8^{\star \star}$
Period $248 \mathrm{H}$

\begin{tabular}{cc}
\hline wt $\%$ & Solvent* \\
Resid & Quality, \\
in Solvent & $\%$ \\
\hline
\end{tabular}

0.0

60.6

85.4

48.6

71.3

$70.7 \star \star$

* wt \% MAF coal conversion to tetrahydrofuran-solubles, as determined by microautoclave test at the following conditions: $9 \mathrm{~g}$ solvent, $6 \mathrm{~g} \mathrm{coal}, 750^{\circ} \mathrm{F}, 30 \mathrm{~min}$.

** From Table 20, this report.

*** Coking sccurred during this test.

Two things are evident from the results: 1) the addition of resid was consistently detrimental to donor solvent quality, and 2) the original tests with whole samples were accurate, in that the tests with solids-free resid gave equivalent results for corresponding samples. Both these conclusions are limited to the samples tested and may not apply to the entire run, however. In earlier. ITSL runs at Wilsonville, before ash recycle became standard practice, the addition of hydrotreated resid to distillate always improved donor solvent quality. The corresponding effect of the addition of interstage resid was inconsistent, but small. Those former results are in sharp contrast to the current ones: in which the presence of resid results in a significant loss in conversion in the microautoclave. Since Run 251 (inclusive), every run has been made with ash recycle and every run has had a minimum of 1 to 2 periods in which the inclusion of ashy hydrogenated resid gave a lower conversion in the microautoclave test than the corresponding distillate only. This often has been attributed (without further verification) to scatter resulting from the high concentrations of solids in these resids. The present results suggest that there may have been periods in which the resid was a contributor to poor solvent quality. 


\section{$850^{\circ} \mathrm{F}+$ RESID CONVERSION AND KINETICS}

Consol analyses of the process 0il: were used to calculate conversions (forced ash balance method) of che $850^{\circ} \mathrm{Ft}$ material and its various components in each reactor stage (Table 21). The $850^{\circ} \mathrm{F}+$ conversions were then used to calculate conversion rate constants and conversion activities (Tabie 22 ). A deactivation rate constant was obtained from these data by a method described later. The conversion and kinetic calculations were made as described elsewhere (1). Briefly, the following equations are used in the calculations:

$$
\begin{aligned}
& C=\text { Conversion }=\left(\frac{850^{\circ} \mathrm{F}+\mathrm{In} / \text { Ash In }-850^{\circ} \mathrm{F}+\text { Out } / \text { Ash Out }}{850^{\circ} \mathrm{F}+\mathrm{In} / \text { Ash In }}\right) \times 100 \% \\
& K=\text { Rate Constant }=\text { WHSV }\left(\frac{\mathrm{C}}{100-\mathrm{C}}\right) \\
& A=\text { Conversion Activity }=\mathrm{KeE}_{\text {act } / R T,}
\end{aligned}
$$

where $E_{\text {act }}$ is assumed to be $23,500 \mathrm{cal} / \mathrm{mol}$, as has been used in the past at Consol (1).

Conversions of $850^{\circ} \mathrm{Ft}$ resid and its components calculated for each reactor stage and total system are given in Table 21. Figure 14 shows the first stage and total $850^{\circ} \mathrm{Ft}$ and coa1+IOM conversions for Run 258. It is clear that: 1) the conversions varied within a range of $\mathrm{ca} .15 \%$ (absolute), and 2) the second stage provided relatively little additional conversion of $850^{\circ} \mathrm{Ft}$ or of coal+10M. The first stage shows net yields (negative conversions) of the soluble resid and its various components. Given in Figure 15 are the second stage conversions of the $850^{\circ} \mathrm{Ft}$ and its components. These vary over a larger range than the first-stage and total $850^{\circ} \mathrm{F}+$ and coal + IOM conversions. 
The trend for each component generaliy follows the trend observed for the $850^{\circ} \mathrm{Ft}$. It appears that in the early part of the run preasphaltenes were being converted into asphaltenes faster than asphaltenes were being converted away (high preasphaltenes conversion and negative conversions of asphaitenes). Conversions in general were lowest during the transitional period $G$ and were relatively high in periods $H$ and $k$. It is not clear why they were higher in period $H$, but in period $K$ the catalyst age was low.

In Table 22, the $850^{\circ} \mathrm{Ft}$ conversions obtained by Consol are compared with those obtained by Wilsonville and the associated kinetic rate constants and conversion activities obtained by consol are given. The average ratios of Consol conversions to Wilsonville conversions (omitting transitional periods $A, G$, and J) are $0.89 \pm 0.12$ for first stage, $0.78 \pm 0.33$ for second stage, and $0.87 \pm 0.11$ for the total system. These are slightly lower than the corresponding global averages found for a comparison involving Wilsonville Runs 250 through 257 (1). However, the average ratios obtained for Run 258 are comparable to the corresponding average ratios obtained for Run 257. The conversions obtained by Consol are slightly low relative to those obtained by Wilsonville because of a difference in laboratory distillation conditions. Consol uses a $850^{\circ} \mathrm{F}$ atm equivalent distillation endpoint, whereas Wilsonville uses a $1050^{\circ} \mathrm{F}$ atm equivalent endpoint. Therefore, Consol is measuring conversion of $850^{\circ} \mathrm{F}$ material, but Wilsonville is measuring conversion of $1050^{\circ} \mathrm{F}+$ material. The effect of this difference on measured conversions has been discussed elsewhere (1).

The kinetic rate constants and conversion activities for each reactor stage are given in Table 22 and plotted in Figures 16 and 17 . The first-stage rate constant and activity were highest around periods $C$ and $H$, with a minimum at period $E$. During periods $C$ and $H$ the coal feed rate was at an intermediate value of ca. $245 \mathrm{MF} \mathrm{lb} / \mathrm{hr}$ and the first stage temperature was ca. $840^{\circ} \mathrm{F}$. Unless the variation seen reflects only experimental noise, the lower first stage rate constant 
and conversion activity during period $E$ resulted from a lower coal feed rate. The second-stage rate constants and conversion activities were relatively high during periods $D, H$, and $K$. Operating conditions were the same during periods $D$ and $H$, except for the different feed coals used. It appears that the higher rate constants and activities in periods $D$ and $H$ resulted from the combination of intermediate coal feed rate with a high $\left(790^{\circ} \mathrm{F}\right)$ catalytic reactor temperature. The high values for period $K$ probably result primarily from the young catalyst age. It is interesting to note in Figure 17 that only after the catalyst was replaced (periods $K, L$, and $M$ ) was the second-stage $850^{\circ} \mathrm{Ft}$ conversion activity higher than that of the first stage.

A catalyst deactivation rate constant was calculated for Run 258 . The calculated deactivation rate is based on rather few data points because almost the entire run was made with equilibrated catalyst at an age of ca. $2500 \mathrm{lb}$ (resid + CI)/lb cat. In order that the calculation would not be skewed by inany data points near that age, all of those data were averaged to a single value (periods $B, C, D, E, F, H$, and I averaged). Transitional periods were omitted from the calculations. The deactivation rate constant is evaluated by considering the conversion activity, $A$, to have an exponential dependence on catalyst age, $t$, as $A=A^{\prime} e^{a t}$, where $A^{\prime}$ is the the initial conversion activity. As written, catalyst deactivation will result in negative values of $a$, the deactivation rate constant. The value of a was determined by regression of $\ln A$ on $t$. Wilsonville uses a different method, in which Eact is variable. Results are given below for each reactor stage (the first stage is included, although it is thermal). 
Catalyst Deactivation Rate Calculation

For Wilsonville Run 258

\begin{tabular}{|c|c|c|c|}
\hline \multirow[b]{2}{*}{ Period } & \multirow{2}{*}{$\begin{array}{c}\text { Cat. Age, Ib } \\
(\text { Resid }+ \text { CI)/ } \\
\text { Ib Cat. } \\
\end{array}$} & \multicolumn{2}{|c|}{ A, $10^{7}$} \\
\hline & & First stage & Second Stage \\
\hline $\begin{array}{l}K \\
L \\
M \\
\text { Equilibrated (Avg. B, } \\
\quad C, D, E, F, H, I)\end{array}$ & $\begin{array}{r}559 \\
1130 \\
1314 \\
2523\end{array}$ & $\begin{array}{l}1.84 \\
1.36 \\
1.57 \\
1.80\end{array}$ & $\begin{array}{l}3.75 \\
2.22 \\
2.16 \\
1.05\end{array}$ \\
\hline
\end{tabular}

First Stage: $\quad \alpha=0.30 \times 10^{-4}, \sigma(\alpha)=1.17 \times 10^{-4}, A^{\prime}=1.56 \times 10^{7}$, $r^{2}=0.03$

Second Stage: $\alpha=-6.2 \times 10^{-4}, \sigma(\alpha)=0.06 \times 10^{-4}, A^{\prime}=4.96 \times 10^{7}$, $r^{2}=0.98$

The results indicate no significant effect of second-stage catalyst age on first stage activity as is expected for the thermal first stage. However, a deactivation rate constant is obtained for the second stage catalyst with a high correlation, although for only four data points. These are illustrated in Figure 18. Both the determined $\alpha$ and $A^{\prime}$ values for second-stage catalyst in Run 258 are within the respective ranges Consol found for Wilsonville Runs 250 through 257. However, the correlation of catalyst activity with age in Run 258 was much stronger than in any of those runs.

\section{EFFECT OF OPERATING VARIABLES ON PROCESS OIL CHARACTERISTICS}

The major portion of Run 258 was operated with catalyst addition/withdrawal and as a result average catalyst age was quite constant for that part of the run. In some cases, only a single operating variable differed between two periods, so that the effect of a change in that variable on process oil characteristics could be examined by comparing the oil properties between two periods. Cases for which this was possible are discussed in the sub-sections to follow. 


\section{Feed Coal}

The two periods for direct comparison of the feed coals are periud $D$ with Spring Creek coal and period $H$ with Black Thunder coal. Other Black Thunder coal periods differed substantially in conditions from those used with Spring Creek coal. For that reason, those periods will not be discussed here. However, those comparative data will be presented in the report section comparing Run 258 oil properties with those of Run 251-II. A comparison of the two run periods $D$ and $H$ can be made by examining Figures 3-13. In general, the properties of oils from the two periods do not differ significantly. The largest difference noted is in the resid solubility fractions. The resids produced from Black Thunder coal (period $H$ ) contained about 6\% more $0 i 1 s, 8 \%$ less asphaltenes, and $2 \%$ more preasphaltenes than corresponding resids produced from Spring Creek coal. While this difference is not large it may represent a real difference in the two coals since the conversion results discussed below also indicate some differences. The $850^{\circ} \mathrm{Ft}^{+}$conversions were somewhat higher during period $H$ (Figures 14-15). However, during period $H$ the second-stage conversion of asphaltenes was about 14\% higher and the second-stage conversion of preasphaltenes was about $14 \%$ lower than in period $D$ (Figure 15). Apparently, because the asphaltenes conversion was higher in period $H$, the measured asphaltenes concentration in the resid samples were lower relative to period $D$. The $850^{\circ} \mathrm{Ft}$ conversion rate constants and activities for period $H$ were slightly higher than in period $D$ (Figures 16-17).

\section{First-Stage Temperature}

Increases in first-stage temperature of $11-12^{\circ} \mathrm{F}$ were made from period $B$ to period $C$ and from period $H$ to period I. Properties of oils from these periods were compared. The interstage resids showed a small (ca. $2 \%$ ) increase in asphaltenes and a corresponding small (ca. 2\%) decrease in preasphaltenes in periods $C$ and I relative to the lower temperature periods $B$ and $H$ preceding them (Figure 8 ). The 
temperature increases were accompanied by increases in distillate and resid aromaticity in all streams (1-4\% increase for distillates, 3-6\% increase for resids) and by decreases of 1-6\% in the distillate paraffinic hydrogens (Figures 9-11). Curiously, the phenolic $-\mathrm{OH}$ concentrations increased from period $B$ to period $C$, but decreased from period $H$ to I (Figure 12). The temperature increase was accompanied by a slight increase in first-stage and total $850^{\circ} \mathrm{Ft}$ conversions in period $C$ (Figure 14). The first stage conversion rate constant increased, but the activity went down (Figures 16-17). The secondstage rate constant and activity went down with the first stage temperature increase in period $\mathrm{C}$. In contrast, the $850^{\circ} \mathrm{F}+$ conversion decreased in period I when the first-stage temperatures increased (Figure 14). No other changes were apparent.

\section{Second-Stage Temperature}

The second-stage temperature was increased by $29-30^{\circ} \mathrm{F}$ from period $\mathrm{C}$ to period $D$ and from period $L$ to period $M$. The $L$ versus $M$ comparison is confounded somewhat by the change from batch catalyst deactivation in $L$ to an addition/withdrawal rate of $3.0 \mathrm{lb} /$ ton in $M$. This confounding effect is probably small, since the sample dates for the two periods differed by only 8 days and the catalyst ages were nearly the same. Almost no significant changes in oil properties accompanied the hydrotreater temperature increases. The one possible exception is the hydrotreated distillate donor solvent quality, which decreased by about $3 \%$ from period $L$ to $M$ (Figure 13). No corresponding change occurred from period $C$ to $D$. The significance of solvent quality change is not clear, since other properties did not change much. However, $850^{\circ} \mathrm{Ft}$ conversions did increase slightly with temperature, both from periods $C$ to $D$ and from periods $L$ to $M$ (Figures 14-15). In both cases, the second-stage rate constant was higher after the temperature increase (Figure 16 ), but only in period $D$ was the conversion activity higher (Figure 17). 


\section{Coal Feed Rate}

From period $D$ to period $E$, the coal feed rate was reduced from 245 to $195 \mathrm{MF} \mathrm{lb} / \mathrm{hr}$. The $\mathrm{V}-131 \mathrm{~B}$ ash content was higher in period $\mathrm{E}$ by $2.8 \%$, perhaps due to sampling error or experimental scatter (Figure 3). The oils concentrations in all resids were higher by about $4 \%$ in period $E$, with corresponding lower preasphaltenes concentrations (Figures 6-8). Distillate and resid aromaticity was higher (1-2\%) and distillate paraffinicity was lower during period $E$, contrary to typical operation at Wilsonville. This effect appears to coincide with Wilsonville's reported loss in catalyst activity, as was addressed earlier in this report. Perhaps for the same reason, the $850^{\circ} \mathrm{F}^{+}$conversions in both stages were slightly lower in period $E$ relative to period $D$ (Figures 14-15). The lower conversions also showed up in low rate constants (Figure 16) and conversion activities (Figure 17).

\section{Catalyst Age}

During the period of batch catalyst deactivation, the catalyst age increased from $c a .600$ to $c a$. $11001 b$ (resid + CI)/ lb cat from period $K$ to period L. The catalyst age increase was accompanied by a small (3\%) decrease in the $0 i 1 \mathrm{~s}$ concentrations of the resids, with corresponding increases in asphaltenes and preasphaltenes concentrations (Figures 6-8). Small (1-2\%) increases in resid aromaticity and distillate paraffinicity were seen in samples from period $L$ relative to period $K$ (Figures 9-11). The phenolic $-\mathrm{OH}$ concentration of the hydrotreated resids increased by about $0.1 \mathrm{meq} / \mathrm{g}$ in period $\mathrm{L}$ (Figure 12). Except for the distillate paraffinicity increase, the changes are not surprising. Overall, the magnitude of the changes is small. The $850^{\circ} \mathrm{F}+$ conversions during period $L$ in both stages were slightly lower (Figures 14-15), as were the corresponding rate constants (Figure 16) and conversion activities (Figure 17). These effects are anticipated for the second stage conversions, but not for the first stage conversions. 
COMPARISON OF WILSONVILLE RUNS 251-II AND RUN 258 PROCESS OIL CHARACTERISTICS

The only previous thermal/catalytic CC-ITSL run made with subbituminous coal was Run 251-II, which used clovis Point (Wyodak) coal and Amocat $1 C$ catalyst. It is of interest to compare process oil characteristics in Run 258 with those in that run, since Wilsonville has had experience processing the clovis Point coal in several runs. However, there were considerable differences in operating conditions between the two runs. Table 23 summarizes the operating conditions used in Run 251-II and two segments of Run 258 using different feed coals. From left to right across the table there is a decrease in reactor volume used, coal concentration in the slurry, and cresol insolubles in the recycle solvent. There is an increase from left to right in resid in the recycle solvent, temperatures in both reactors, and WHSV. The catalyst age roughly follows the trend 251-II(A-D)< $258(H-M)<258(A-G)$, although periods $K$ through $M$ of Run 258 have the lowest catalyst ages. Being aware that considerable differences existed between the two runs, the process oil characteristics can be compared. However, it is likely that any differences due to feed coal properties are obscured by the differences in processing conditions.

Process $0 i 1$ characteristics for the two runs are given in Table 24. Data from Run 251-II were obtained from a previous report ( 8 ). The solvent qualities are compared by using a predicted Solvent quality Index (SQI) because the standard coal used in microautoclave tests was changed between the two sets of analyses. The SQI is predicted from the distillate proton distribution using equations reported previously by Consol ( $(\underline{9})$. The SQI of distillates from all three periods being compared were similar, except that the interstage distillates from the Black Thunder coal operation were at the low end of the range. There is a substantial increase in the aromaticity of the oils from left to right across the table. Increasing space velocity is probably a major factor, although increasing temperature in the thermal stage and the decrease in reactor volume used (which increases the thermal/catalytic 
reaction volume) are also likely contributors to the effect. There is an effect of decreasing paraffinicity as aromaticity increases from left to right. Except for the interstage resid, which did not vary among the runs or run periods, the Run 258 oils contained higher concentrations of phenolic $-\mathrm{OH}$ than the Run 251-II oils. This probably results from the same factors affecting aromaticity since past experience has typically shown a high correlation between aromaticity and phenolic $-\mathrm{OH}$ concentration. The phenolic $-\mathrm{OH}$ concentration during the Black Thunder coal operation of Run 258 was slightly lower than in the spring creek coal operation. The results therefore seem to roughly correspond to the trend in catalyst ages 25I-II(A-D) $<258(H-M)$ $<258(A-G)$.

The resid components (Table 24 ) increase in preasphaltenes from Run 251-II through Run 258, and thus appear to be dominated by factors such as space velocity, reactor temperatures and reactor volume. The oils concentrations in the resids were lower during Run 258. However, the hydrogenated resid oils concentrations showed a trend of 251$\mathrm{II}(A-D)>258(H-M)>258(A-G)$, which is inversely related to catalyst age. The hydrogenated resid asphaltenes concentrations appear to correlate directly with catalyst age. For the interstage resid, however, the asphaltene concentration followed the trend 251-II(A-D) = $258(A-G)>258(H-M)$. Thus, the hydrogenated resid had relatively higher asphaltenes content during Run 258, whereas the interstage resid had relatively lower asphaltenes content during Run 258 . This may be related to coal differences during Run 258, since asphaltenes concentrations of the hydrogenated and interstage resids were lower during the Black Thunder portion of Run 258 than during the Spring creek portion.

Conversions of $850^{\circ} \mathrm{Ft}$ for the two runs are given in Table 24 . Run 258 first stage and total conversions were low relative to those in Run $1-11$. Even though the resid concentration in the recycle solvent was much higher in Run 258 than in Run $251-$ II (41\% vs 25\%), the production of $850^{\circ} \mathrm{F}^{-}$in the first stage per unit of coal fed was 
still lower. Since the second-stage conversions were comparable, it appears that the major contributor to lower conversions in Run 258 is the higher space velocity (i.e., catalyst age does not appear to be a factor). Of course, the 50\% reactor volume in Run 258 may also be a factor in the lower conversions, due to differences in reactor dynamics relative to Run 251-II.

Also given in Table 24 are the rate constants and activities for $850^{\circ} \mathrm{Ft}$ conversions. The first-stage rate constant and activity for Run 251-II were substantially higher than those for the two portions of Run 258 (which were about equivalent to each other). In the second stage, the rate constants followed the trend 251-II $=258(A-G)<$ $258(H-M)$ and the activities followed the trend $258(A-G) \leq 251-11<$ 258(H-M). The second-stage activities apparently were dominated by catalyst age, since the highest periods of activity were $K-M$ in Run 258. This caused $258(H-M)$ to be higher in second-stage activity than 251 -II and $258(A-G)$. 
Section 3

EXPERIMENTAL

Experimental details are described, where appropriate, in the Discussion section of this report. Details of the other analytical techniques used in this work were reported previously $(\underline{5,6})$. 


\section{Section 4}

REFERENCES

1. Burke, F. P.; Winsche1, R. A.; Robbins, G. A. "Coal Liquefaction Process Solvent Characterization and Evaluation - Final Report", DOE Contract DE-AC22-84PC70018, August 1989.

2. Winsche1, R. A.; Robbins, G. A.; Burke, F. P. "Coal Liquefaction Process Solverit Characterization and Evaluation, Technical Progress Report, January 1 through March 31, 1988", DOE Contract No. DE-AC22-84PC70018, March 1989.

3. Southern Clean Fuels, Wilsonville Advanced Coal Liquefaction R\&D Facility, Handouts from Technical Meeting No. 99 (July 12, 1989), No. 100 (September 13, 1989), No. 101 (November 15, 1989), and No. 102 (January 24, 1990).

4. Stearns-Catalytic Corp., Advanced Coal Liquefaction R\&D Facility; Minutes of Technical Review Meeting No. 34 (January 14, 1987), No. 85 (March 18, 1987), No. 86 (May 20, 1987), No. 87 (July 16, 1987), and No. 88 (September 17, 1987).

5. Burke, F. P.; Winsche1, R. A.; Robbins, G. A. "Recycle Slurry 011 Characterization Final Report - October 1983 through March 1984", DOE Contract DE-AC22-80PC30027, March 1985.

6. Winsche1, R. A.; Robbins, G. A.; Burke, F. P. "Coal Liquefaction Process Solvent Characterization and Evaluation, Technical Progress Report, July 1 through September 30, 1985", DOE Contract DE-AC22-84PC70018, December 1985.

7. Winschel, R. A.; Robbins, G. A.; Burke, F. P. "Coal Liquefaction Process Solvent Characterization and Evaluation, Technical Progress Report, January 1 through March 31, 1986", DOE Contract DE-AC22-84PC70018, JuTy 1986.

8. Robbins, G. A.; Winschel, R. A.; Burke, F. P. "Coal Liquefaction Process Solvent Characterization and Evaluation, Technical Progress Report, Ju1y 1 through September 30, 1987", DOE Contract No. DE-AC22-84PC70018, March 1989.

9. Winschel, R.A.; Robbins, G. A.; Burke, F.P. "Correlation of Microautoclave and ${ }^{1 H}$-NMR Measurements of Coal Liquefaction Solvent Quality", Fuel 1986, 65, 526-532. 


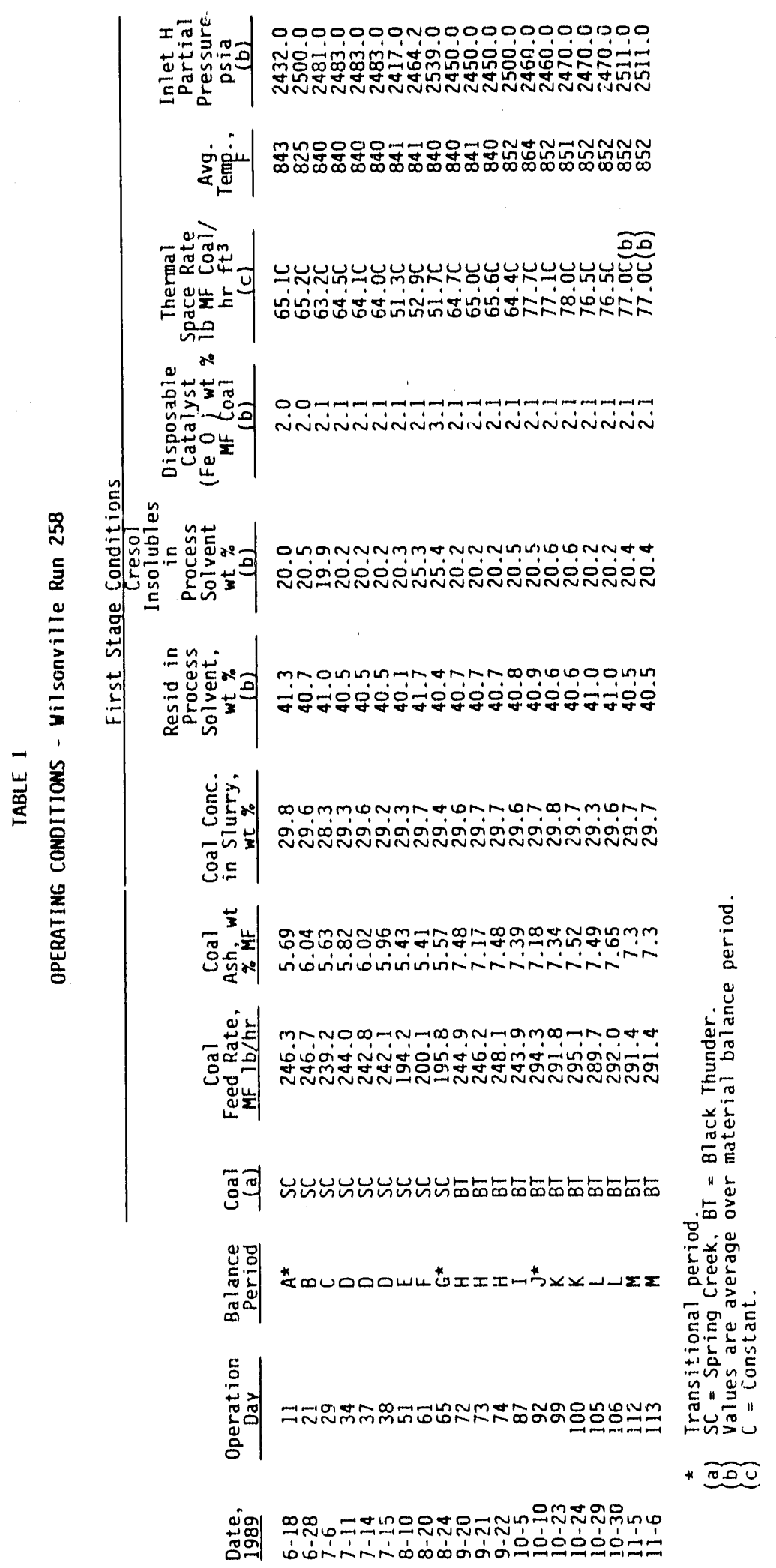




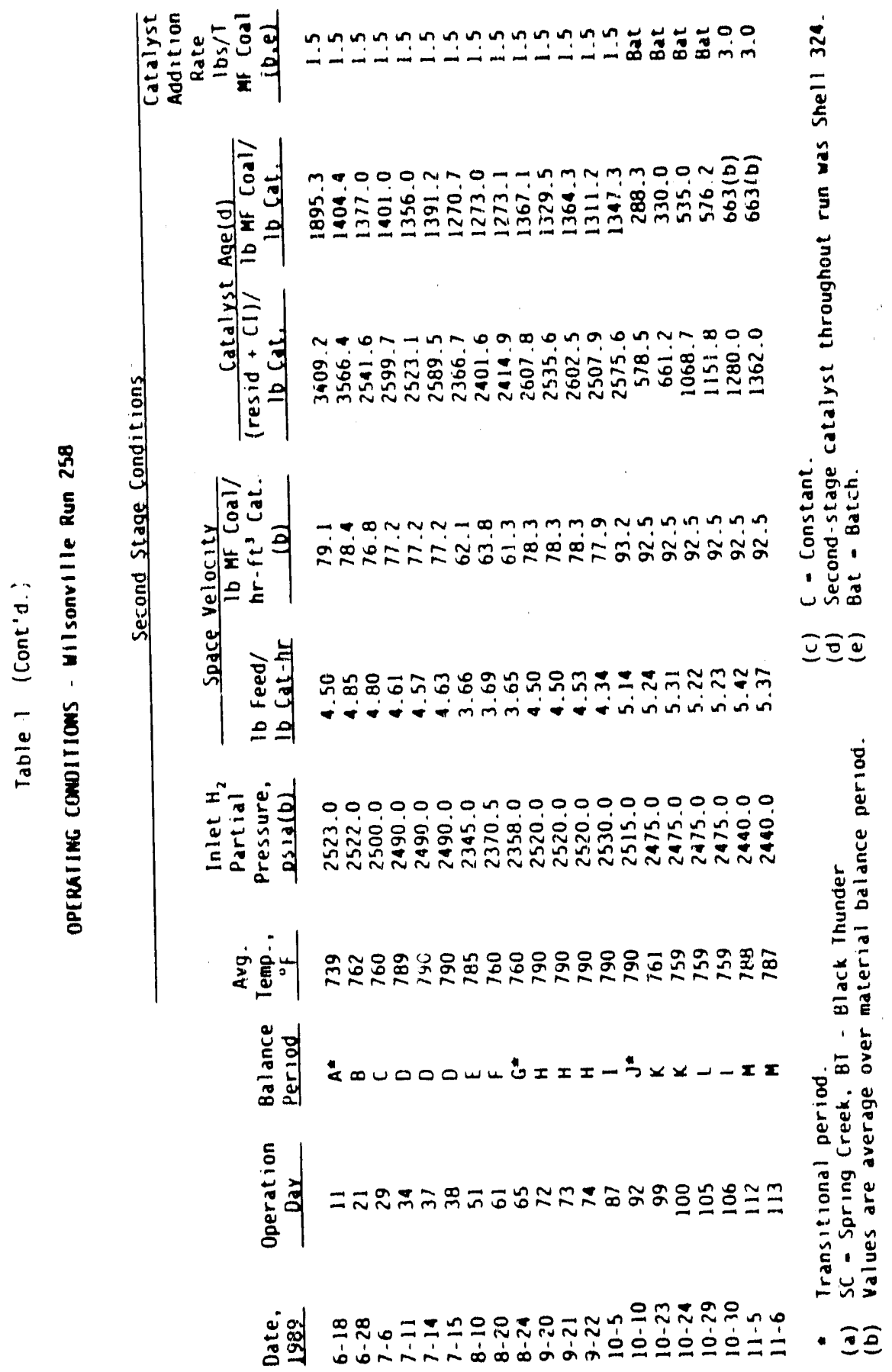




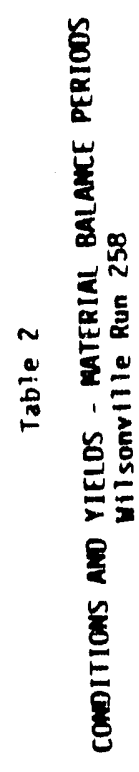

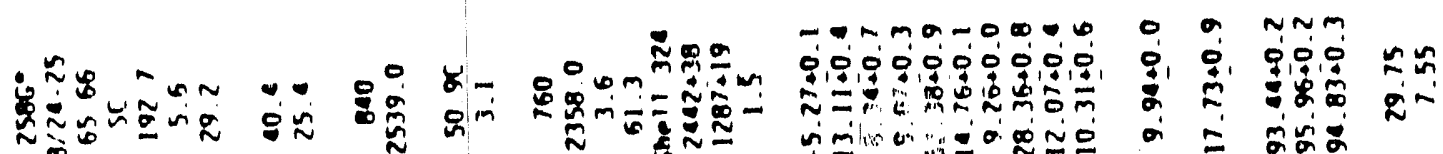

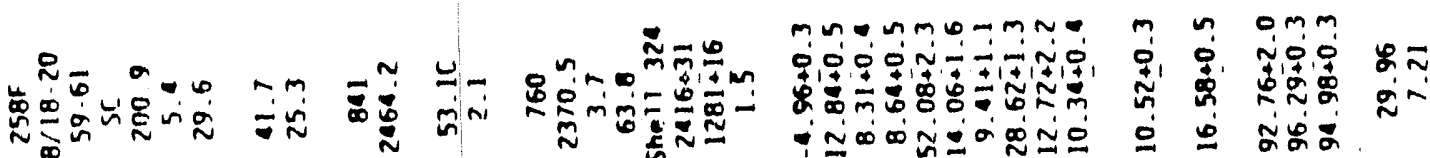

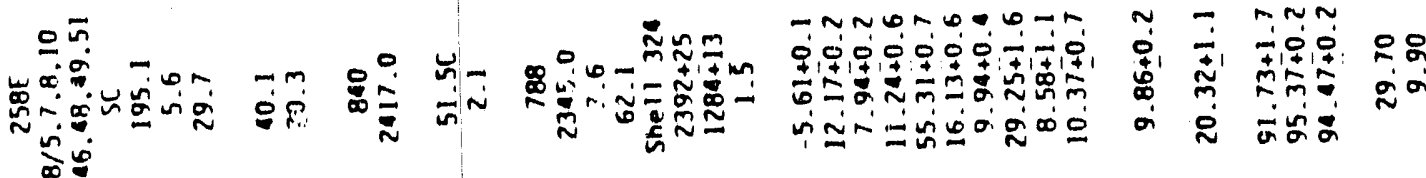

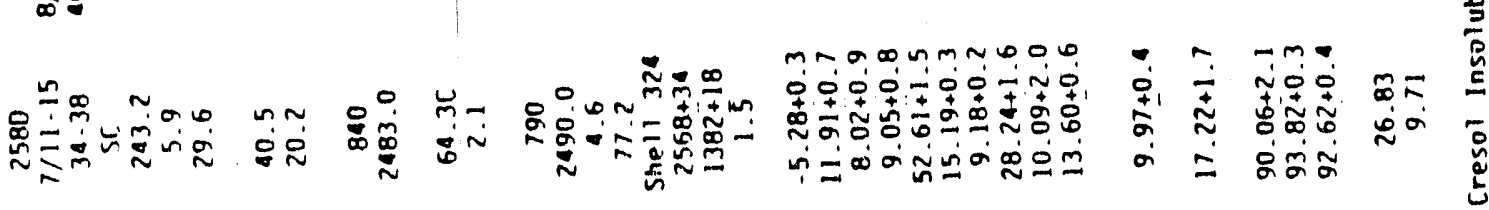

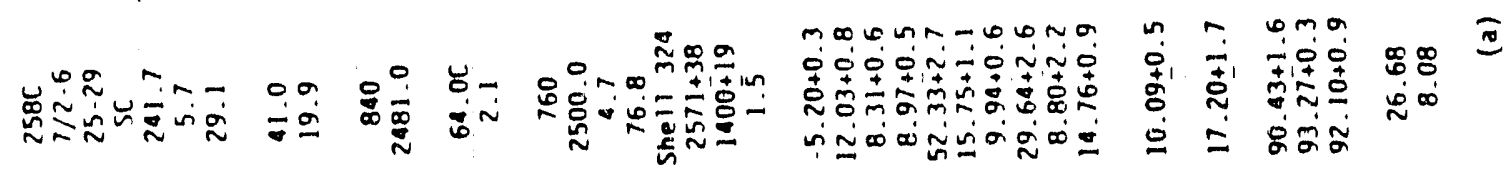

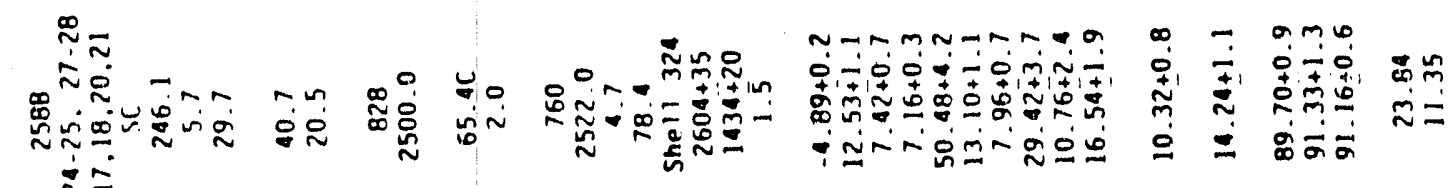
$\frac{1}{2}=$

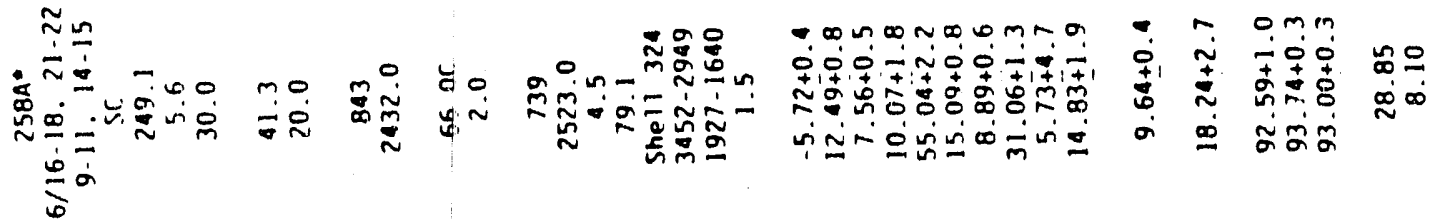

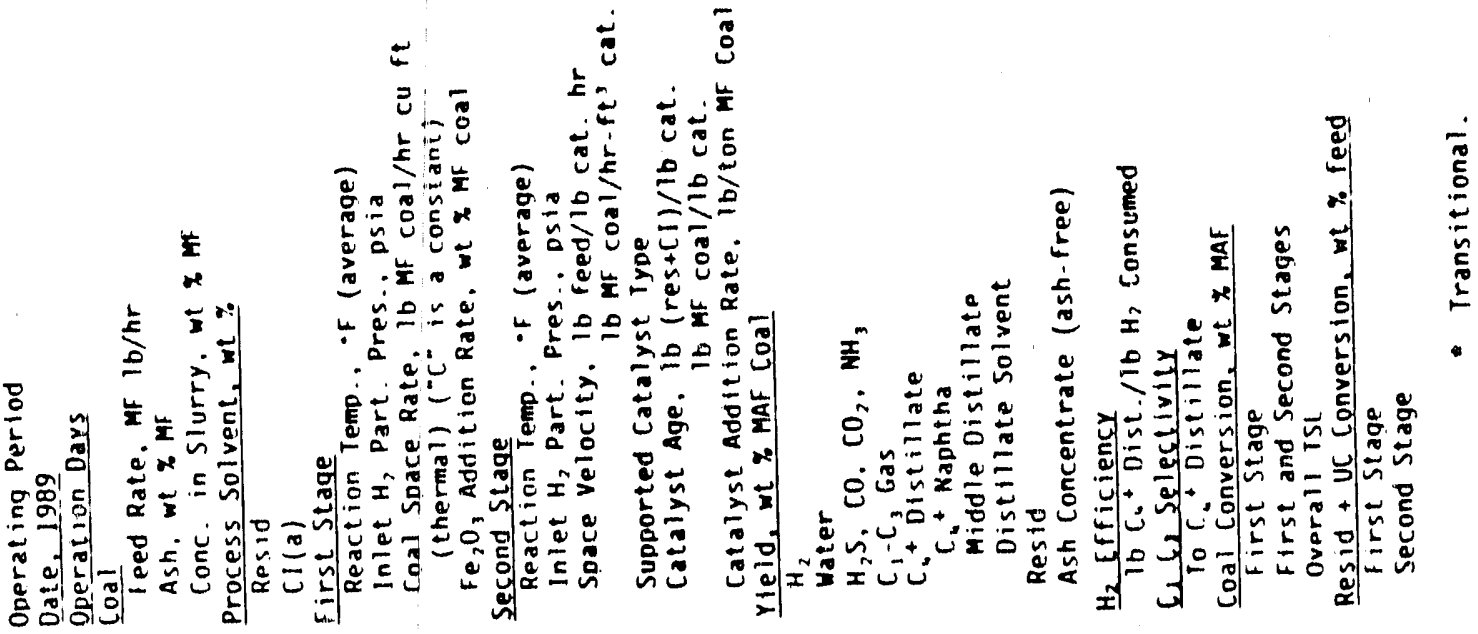




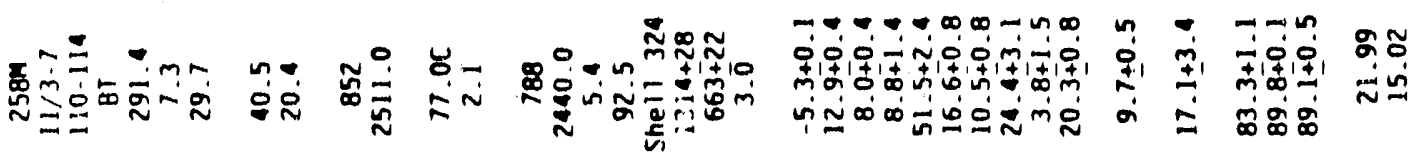

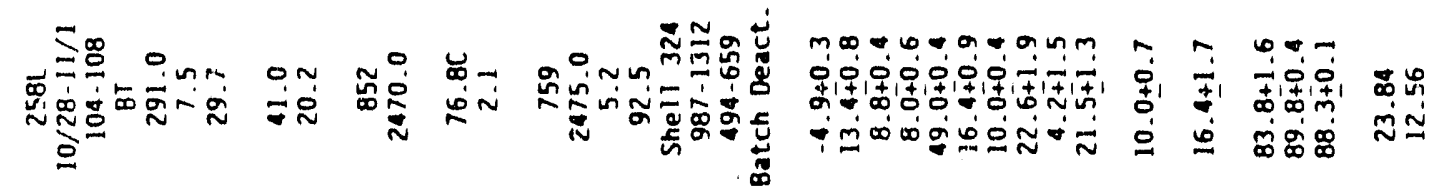

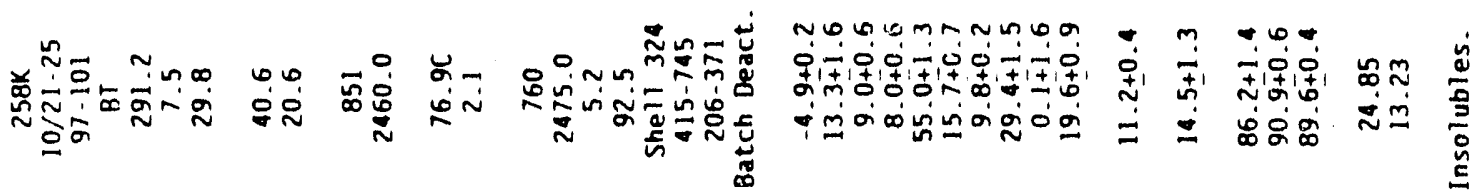

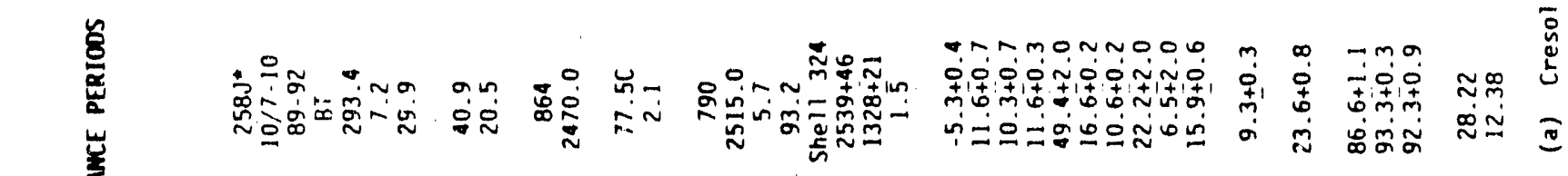

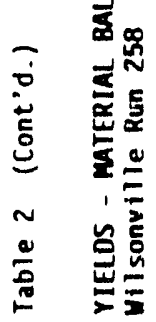

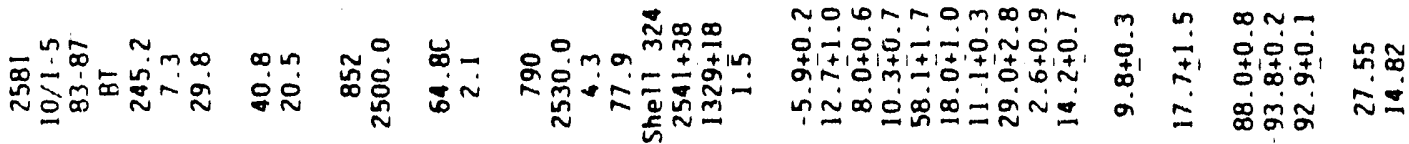

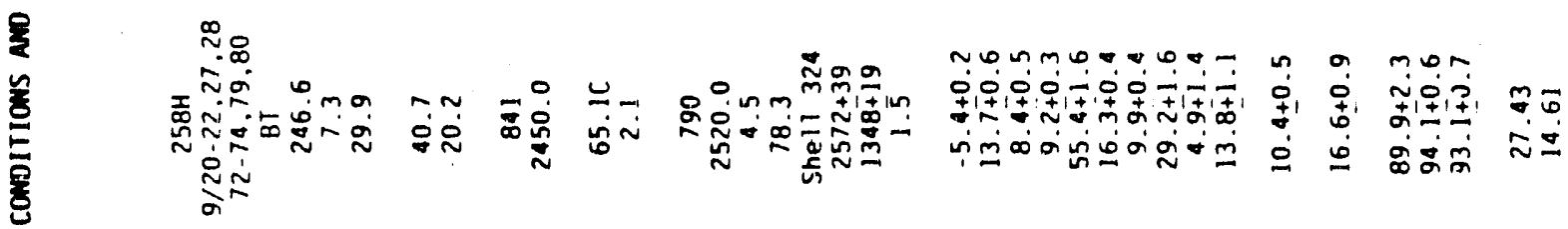

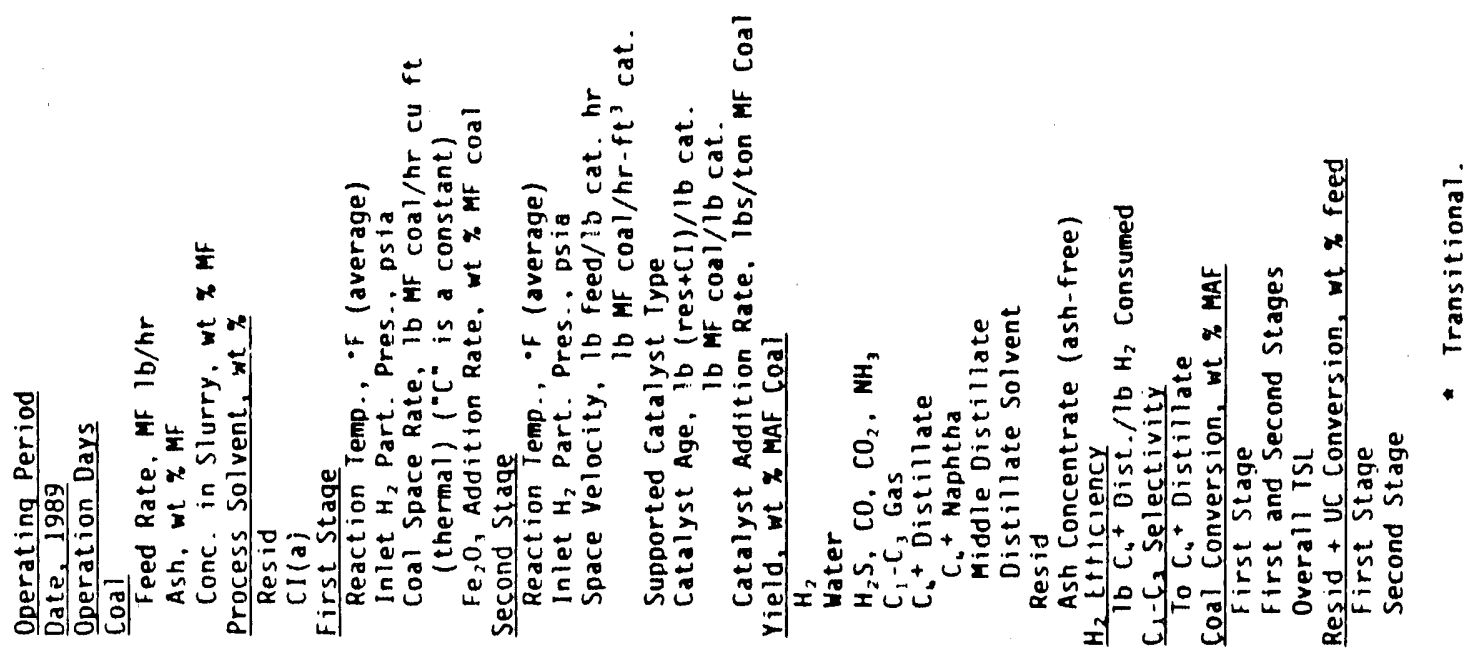


TABLE 3

ANALYSES OF SUBBITUMINOUS FEED COALS

Wilsonville Run 258

\begin{tabular}{|c|c|c|}
\hline & Spring Creek & Black Thunder \\
\hline Wilsonville Sample No. & 95345 & 99460 \\
\hline Moisture, wt io as det. & 10.32 & 24.10 \\
\hline $\begin{array}{l}\text { Proximate, wt \% Dry Basis } \\
\text { Volatile Matter } \\
\text { Fixed Carbon } \\
\text { Ash }\end{array}$ & $\begin{array}{r}42.16 \\
51.98 \\
5.86\end{array}$ & $\begin{array}{r}45.72 \\
47.11 \\
7.17\end{array}$ \\
\hline $\begin{array}{l}\text { Ultimate, wt \% MAF Basis } \\
\text { Carbon } \\
\text { Hydroger } \\
\text { Nitrogen } \\
\text { Oxygen (diff.) } \\
\text { Sulfur, Total } \\
\text { Pyrite } \\
\text { Sulfate } \\
\text { Organic (diff.) } \\
\text { Chlorine }\end{array}$ & $\begin{array}{r}76.64 \\
5.01 \\
1.05 \\
16.90 \\
0.39 \\
0.04 \\
0.02 \\
0.33 \\
<0.011\end{array}$ & $\begin{array}{r}74.76 \\
5.18 \\
1.17 \\
18.32 \\
0.56 \\
0.12 \\
0.05 \\
0.39 \\
<0.011\end{array}$ \\
\hline HHV, Btu/1b MAF Basis & 13192 & 12711 \\
\hline $\begin{array}{l}\text { Elemental, wt \% of Ash } \\
\mathrm{Na}_{2} \mathrm{O} \\
\mathrm{K}_{2} \mathrm{O} \\
\mathrm{CaO} \\
\mathrm{MgO} \\
\mathrm{Fe}_{2} \mathrm{O}_{3} \\
\mathrm{TiO}_{2} \\
\mathrm{P}_{2} \mathrm{O}_{5} \\
\mathrm{SiO}_{2} \\
\mathrm{Al}_{2} \mathrm{O}_{3} \\
\mathrm{SO}_{3} \\
\text { Unaccounted }\end{array}$ & $\begin{array}{r}4.55 \\
0.94 \\
12.84 \\
3.58 \\
5.88 \\
1.02 \\
0.25 \\
37.01 \\
16.95 \\
15.75 \\
1.23\end{array}$ & $\begin{array}{r}0.59 \\
0.38 \\
19.66 \\
4.02 \\
5.71 \\
1.08 \\
0.93 \\
33.00 \\
15.68 \\
18.74 \\
0.21\end{array}$ \\
\hline
\end{tabular}




\section{TABLE 4}

\section{COMPONENT DISTRIBUTION OF $V$-131B SAMPLES \\ Wilsonville Run 258}

Sample

$\begin{array}{ccc}\text { Date } & \text { Time } & \text { Number } \\ 6-18-89 & 2055 & 96211 \\ 6-28-89 & 0525 & 96707 \\ 7-06-89 & 0545 & 97136 \\ 7-14-89 & 0550 & 97564 \\ 8-10-89 & 1205 & 98328 \\ 8-20-89 & 2325 & 98774 \\ 8-24-89 & 0415 & 98920 \\ 9-22-89 & 1440 & 99495 \\ 10-05-89 & 1655 & 1177 \\ 10-10-89 & 1810 & 1438 \\ 10-24-89 & 1335 & 1872 \\ 10-29-89 & 1740 & 2157 \\ 11-06-89 & 0550 & 2531\end{array}$

Wt $\%$ of Sample

\begin{tabular}{ccrrr}
\multicolumn{8}{c}{$\begin{array}{c}\text { W5 } \% \text { F } \\
\text { Distillate }\end{array}$} & $\begin{array}{c}\text { THF-Soluble } \\
\text { Resid }\end{array}$ & & IOM & Ash \\
\cline { 2 - 2 } 27.2 & 51.0 & 9.2 & 11.8 \\
29.6 & 43.0 & 10.8 & 10.3 \\
31.2 & 45.8 & 9.3 & 12.0 \\
30.4 & 47.7 & 9.0 & 11.5 \\
28.6 & 47.6 & & 8.8 & 14.3 \\
26.2 & 46.0 & 9.3 & 16.7 \\
25.9 & 46.3 & 9.4 & 16.9 \\
31.6 & 48.6 & 7.3 & 12.1 \\
30.9 & 48.3 & 8.1 & 12.4 \\
32.2 & 48.1 & 7.9 & 11.2 \\
30.4 & 49.6 & 9.3 & 9.8 \\
31.7 & 48.3 & 9.8 & 9.5 \\
32.2 & 47.8 & 9.5 & 9.6
\end{tabular}


TABLE 5

COMPONENT DISTRIBUTION OF $V$-1067 SAMPLES

WILSONVILLE RUN 258

Sample

\begin{tabular}{ccc}
\multicolumn{3}{c}{ Sample } \\
\hline Date & Time & Number \\
$6-18-89$ & DC & 96197 \\
$6-28-89$ & DC & 96727 \\
$7-06-89$ & DC & 97163 \\
$7-11-89$ & DC & 97422 \\
$8-10-89$ & 1500 & 98316 \\
$8-20-89$ & DC & 98755 \\
$8-24-89$ & 2300 & 98913 \\
$9-20-89$ & DC & 99388 \\
$10-05-89$ & DC & 1164 \\
$10-10-89$ & 1500 & 1423 \\
$10-23-89$ & 1500 & 1809 \\
$10-29-89$ & 1500 & 2135 \\
$11-05-89$ & 1500 & 2503
\end{tabular}

Wt $\%$ of Sample

\begin{tabular}{|c|c|c|c|}
\hline $\begin{array}{c}850^{\circ} \mathrm{F}- \\
\text { Distillate } \\
\end{array}$ & $\begin{array}{l}\text { THF-Soluble } \\
\text { Resid } \\
\end{array}$ & IOM & Ash \\
\hline 28.9 & 47.5 & 10.1 & 12.7 \\
\hline 26.2 & 48.6 & 11.4 & 11.5 \\
\hline 26.7 & 48.3 & 10.4 & 12.3 \\
\hline 26.7 & 47.9 & 10.2 & 13.2 \\
\hline 30.4 & 46.4 & 8.9 & 13.5 \\
\hline 24.9 & 47.0 & 9.7 & 16.2 \\
\hline 25.7 & 47.1 & 9.1 & 15.8 \\
\hline 27.9 & 47.7 & 8.4 & 15.5 \\
\hline 27.3 & 48.8 & 9.4 & 14.0 \\
\hline 25.4 & 48.6 & 11.3 & 13.3 \\
\hline 28.3 & 46.0 & 12.0 & 12.8 \\
\hline 25.4 & 49.1 & 12.6 & 11.8 \\
\hline 24.8 & 49.0 & 13.0 & 12.7 \\
\hline
\end{tabular}


TABLE 6

COMPONENT DISTRIBUTION OF R-1235 SAMPLES

Wilsonville Run 258

Sample

$\begin{array}{ccc}\text { Date } & \text { Time } & \text { Number } \\ \text { 6-18-89 } & 1700 & 96209 \\ 6-28-89 & 1700 & 96726 \\ 7-06-89 & 1700 & 97180 \\ 7-15-89 & 1700 & 97660 \\ 8-10-89 & 0500 & 98296 \\ 8-20-89 & 0500 & 98237 \\ 8-24-89 & 0500 & 98921 \\ 9-21-89 & 2030 & 99442 \\ 10-05-89 & 1700 & 1175 \\ 10-10-89 & 1700 & 1437 \\ 10-24-89 & 1700 & 1896 \\ 10-30-89 & 0500 & 2168 \\ 11-05-89 & 0500 & 2481\end{array}$

Wt $\%$ of Sample

\begin{tabular}{ccrr}
$\begin{array}{c}850^{\circ} \mathrm{F}- \\
\text { Distillate }\end{array}$ & $\begin{array}{c}\text { THF-Soluble } \\
\text { Resid }\end{array}$ & IOM & Ash \\
\cline { 1 - 2 } 26.3 & 51.2 & 9.5 & 12.4 \\
23.6 & 49.5 & 13.4 & 11.4 \\
26.2 & 48.9 & 10.8 & 11.9 \\
26.8 & 49.0 & 11.0 & 11.9 \\
26.4 & 49.3 & 10.2 & 13.3 \\
25.1 & 47.6 & 10.6 & 16.2 \\
26.0 & 46.5 & 9.7 & 16.5 \\
25.4 & 50.1 & 9.7 & 14.0 \\
25.0 & 49.9 & 10.3 & 13.9 \\
24.5 & 50.1 & 11.3 & 13.3 \\
23.4 & 50.4 & 13.2 & 11.8 \\
24.8 & 49.4 & 13.9 & 10.9 \\
24.4 & 48.2 & 15.0 & 11.2
\end{tabular}


TABLE 7

SOLUBILITY FRACTIONATION OF $V$-131B SAMPLES

Wilsonville Run 258

Wt $\%$ of THF-Soluble Resid

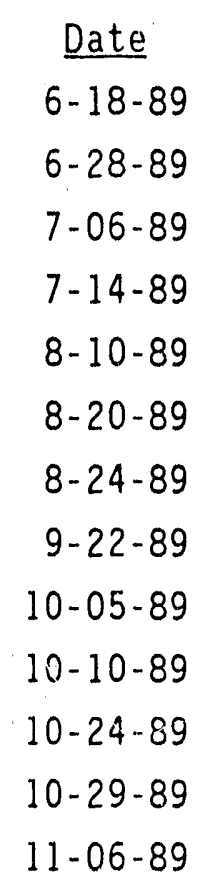

Asphaltenes

Preasphaltenes

$\underline{0 i 7 s}$

57.0

30.4

12.6

55.8

30.0

14.2

54.7

33.5

11.8

54.7

30.9

14.4

58.5

29.9

11.6

55.5

30.3

14.2

58.1

29.1

12.9

60.2

23.9

15.9

60.6

23.4

16.0

61.8

23.7

14.5

61.8

22.8

15.4

57.9

25.6

16.5

58.0

26.1

15.9 


\section{TABLE 8}

\section{SOLUBILITY FRACTIONATION OF V-1067 SAMPLES \\ Wilsonville Run 258}

\begin{tabular}{cccc} 
& \multicolumn{3}{c}{ Wt $\%$ of THF-Soluble Resid } \\
\cline { 2 - 4 } Date & $\underline{0 i 1 s}$ & $\frac{\text { Asphaltenes }}{30.3}$ & $\frac{\text { Preasphaltenes }}{18-89}$ \\
$6-18.4$ & 31.1 & 13.3 \\
$6-28-89$ & 51.8 & 32.4 & 17.1 \\
$7-06-89$ & 51.4 & 33.7 & 16.2 \\
$7-11-89$ & 52.8 & 31.3 & 13.4 \\
$8-10-89$ & 57.5 & 31.4 & 11.2 \\
$8-20-89$ & 55.7 & 30.3 & 12.8 \\
$8-24-89$ & 56.0 & 22.6 & 13.7 \\
$9-20-89$ & 59.5 & 23.7 & 17.9 \\
$10-05-89$ & 57.4 & 24.1 & 19.0 \\
$10-10-89$ & 60.4 & 24.6 & 15.5 \\
$10-23-89$ & 58.5 & 26.5 & 17.0 \\
$10-29-89$ & 55.6 & 26.7 & 17.9 \\
$11-05-89$ & 56.3 & & 17.0
\end{tabular}


TABLE 9

\section{SOLUBILITY FRACTIONATION OF R-1235 SAMPLES}

Wilsonville Run 258

Wt $\%$ of THF-Soluble Resid

\begin{tabular}{lccc}
\multicolumn{1}{c}{ Date } & $\underline{0 i 1 \mathrm{~s}}$ & Asphaltenes & Preasphaltenes \\
$6-18-89$ & 54.8 & 25.8 & 19.4 \\
$6-28-89$ & 51.0 & 26.4 & 22.6 \\
$7-06-89$ & 51.9 & 27.9 & 20.2 \\
$7-15-89$ & 49.4 & 30.0 & 20.6 \\
$8-10-89$ & 53.2 & 29.7 & 17.1 \\
$8-20-89$ & 54.1 & 29.7 & 16.3 \\
$8-24-89$ & 57.5 & 28.4 & 14.1 \\
$9-21-89$ & 55.6 & 22.8 & 21.5 \\
$10-05-89$ & 55.8 & 24.8 & 19.3 \\
$10-10-89$ & 57.9 & 25.0 & 17.0 \\
$10-24-89$ & 57.1 & 23.9 & 19.0 \\
$10-30-89$ & 54.1 & 26.6 & 19.3 \\
$11-05-89$ & 55.8 & 26.9 & 17.3
\end{tabular}


TABLE 10

PROTON DISTRIBUTION OF V-131B WHOLE SAMPLES

Wilsonville Run 258

\begin{tabular}{ccccccccc} 
& \multicolumn{8}{c}{ Proton Distribution, $\%$} \\
\cline { 2 - 5 } Date & $\begin{array}{c}\text { Cond } \\
\text { Arom }\end{array}$ & $\begin{array}{c}\text { Uncond } \\
\text { Arom }\end{array}$ & $\begin{array}{c}\text { Cyclic } \\
\text { Alpha }\end{array}$ & $\begin{array}{c}\text { Alkyl } \\
\text { Alpha }\end{array}$ & $\begin{array}{c}\text { Cyclic } \\
\text { Beta }\end{array}$ & $\begin{array}{c}\text { Alkyl } \\
\text { Beta }\end{array}$ & Gamma \\
6-18-89 & 20.0 & 4.8 & 17.9 & 9.5 & 16.0 & 20.6 & 11.3 \\
$6-28-89$ & 19.4 & 3.3 & 18.9 & 9.2 & 17.0 & 21.4 & 10.8 \\
$7-06-89$ & 22.1 & 3.3 & 19.4 & 9.6 & 15.9 & 19.9 & 9.7 \\
$7-14-89$ & 23.9 & 3.5 & 19.1 & 9.5 & 14.7 & 19.2 & 10.2 \\
$8-10-89$ & 25.3 & 4.2 & 18.7 & 9.3 & 14.4 & 18.4 & 9.7 \\
$8-20-89$ & 24.2 & 4.7 & 18.8 & 9.6 & 15.0 & 19.0 & 8.8 \\
$8-24-89$ & 24.5 & 4.2 & 18.8 & 9.5 & 14.8 & 18.8 & 9.4 \\
$9-22-89$ & 23.1 & 5.1 & 17.6 & 10.1 & 13.9 & 18.9 & 11.3 \\
$10-05-89$ & 24.9 & 5.4 & 18.1 & 10.1 & 13.7 & 17.1 & 10.7 \\
$10-10-89$ & 32.7 & 4.8 & 18.6 & 9.3 & 12.3 & 14.6 & 7.7 \\
$10-24-89$ & 24.3 & 4.8 & 18.7 & 10.0 & 14.6 & 18.2 & 9.3 \\
$10-29-89$ & 24.9 & 4.1 & 18.8 & 9.8 & 15.1 & 18.5 & 8.8 \\
$11-06-89$ & 26.5 & 6.0 & 18.0 & 9.2 & 13.5 & 17.2 & 9.7
\end{tabular}


TABLE 11

PROTON DISTRIBUTION OF V-1067 WHOLE SAMPLES

WILSONVILLE RUN 258

\begin{tabular}{cccccccc} 
& \multicolumn{8}{c}{ Proton Distribution, $\%$} \\
\cline { 2 - 7 } Date & Cond & Uncond & \multicolumn{1}{c}{ Cyclic } & Alky1 & Cyclic & Alkyl \\
6-18-89 & 19.3 & 5.5 & 17.6 & 9.8 & 16.2 & 20.2 & 11.3 \\
A-28-89 & 19.7 & 3.9 & 18.3 & 9.6 & 16.3 & 21.2 & 11.2 \\
$7-06-89$ & 22.4 & 3.5 & 20.4 & 10.1 & 16.2 & 19.5 & 7.9 \\
$7-11-89$ & 22.8 & 4.6 & 19.0 & 9.7 & 14.8 & 18.9 & 10.2 \\
8-10-89 & 25.2 & 4.0 & 19.7 & 9.3 & 14.5 & 18.3 & 9.1 \\
8-20-89 & 23.9 & 5.3 & 19.0 & 9.3 & 13.7 & 18.8 & 10.1 \\
8-24-89 & 24.3 & 3.9 & 19.1 & 9.5 & 14.5 & 19.4 & 9.4 \\
$9-20-89$ & 21.9 & 6.8 & 17.3 & 10.4 & 14.1 & 17.4 & 12.1 \\
$10-05-89$ & 26.0 & 6.1 & 17.7 & 9.3 & 13.7 & 17.7 & 9.5 \\
$10-10-89$ & 33.1 & 3.9 & 19.8 & 9.5 & 12.6 & 14.2 & 7.0 \\
$10-23-89$ & 25.8 & 4.1 & 19.3 & 9.6 & 15.0 & 17.3 & 9.0 \\
$10-29-89$ & 25.4 & 4.7 & 18.9 & 9.4 & 14.9 & 17.6 & 9.1 \\
$11-05-89$ & 24.0 & 5.7 & 16.8 & 9.4 & 13.6 & 19.1 & 11.3
\end{tabular}


TABLE 12

PROTON DISTRIBUTION OF R-1235 WHOLE SAMPLES Wilsonville Run 258

\begin{tabular}{cccccccc} 
& \multicolumn{8}{c}{ Proton Distribution, $\%$} \\
\cline { 2 - 6 } Date & $\begin{array}{c}\text { Cond } \\
\text { Arom }\end{array}$ & $\begin{array}{c}\text { Uncond } \\
\text { Arom }\end{array}$ & $\begin{array}{c}\text { Cyclic } \\
\text { Alpha }\end{array}$ & $\begin{array}{c}\text { Alkyl } \\
\text { Alpha }\end{array}$ & $\begin{array}{c}\text { Cyclic } \\
\text { Beta }\end{array}$ & $\begin{array}{c}\text { Alkyl } \\
\text { Beta }\end{array}$ & Gamma \\
6-18-89 & 22.9 & 7.1 & 17.1 & 10.0 & 13.9 & 18.6 & 10.4 \\
$6-28-89$ & 23.3 & 4.0 & 19.4 & 10.2 & 14.5 & 18.9 & 9.8 \\
$7-06-89$ & 25.3 & 4.2 & 19.2 & 10.3 & 14.2 & 17.9 & 8.9 \\
$7-15-89$ & 26.9 & 3.8 & 19.7 & 10.1 & 13.2 & 17.8 & 8.5 \\
$8-10-89$ & 27.8 & 3.9 & 19.2 & 10.2 & 12.8 & 17.6 & 8.5 \\
$8-20-89$ & 26.9 & 5.4 & 18.8 & 10.2 & 12.9 & 16.9 & 8.9 \\
$8-24-89$ & 25.9 & 5.9 & 17.8 & 10.6 & 12.6 & 17.7 & 9.5 \\
$9-21-89$ & 27.3 & 6.0 & 18.6 & 10.4 & 12.5 & 15.0 & 10.2 \\
$10-05-89$ & 24.9 & 5.4 & 18.1 & 10.1 & 13.7 & 17.1 & 10.7 \\
$10-10-89$ & 36.1 & 5.1 & 18.2 & 10.0 & 10.0 & 13.3 & 6.5 \\
$10-24-89$ & 31.2 & 5.8 & 18.0 & 10.1 & 11.2 & 15.8 & 7.8 \\
$10-30-89$ & 31.2 & 4.6 & 18.8 & 10.0 & 12.0 & 16.0 & 7.3 \\
$11-05-89$ & 31.2 & 6.1 & 17.6 & 9.9 & 10.9 & 16.4 & 8.0
\end{tabular}


TABLE 13

PROTON DISTRIBUTION OF $V$-131B DISTILLATE SAMPLES

Wilsonville Run 258

\begin{tabular}{cccccccc} 
& \multicolumn{8}{c}{$\begin{array}{c}\text { Proton } \\
\text { Date }\end{array}$} & $\begin{array}{c}\text { Cond } \\
\text { Arom }\end{array}$ & $\begin{array}{c}\text { Uncond } \\
\text { Arom }\end{array}$ & $\begin{array}{c}\text { Cyclic } \\
\text { Alpha }\end{array}$ & $\begin{array}{c}\text { Alky } \\
\text { Alpha }\end{array}$ & $\begin{array}{c}\text { Cyclic } \\
\text { Beta }\end{array}$ & $\begin{array}{c}\text { Alkyl } \\
\text { Beta }\end{array}$ & Gamma \\
\cline { 3 - 6 } $6-18-89$ & 10.5 & 5.2 & 14.8 & 9.8 & 18.2 & 27.3 & 14.3 \\
$6-28-89$ & 10.1 & 5.5 & 14.9 & 9.7 & 18.2 & 27.5 & 14.0 \\
$7-06-89$ & 13.0 & 4.6 & 17.5 & 10.0 & 17.8 & 25.3 & 11.9 \\
$7-14-89$ & 13.2 & 5.7 & 14.9 & 9.6 & 16.4 & 26.5 & 13.7 \\
$8-10-89$ & 13.9 & 6.4 & 16.2 & 9.6 & 15.9 & 25.9 & 12.0 \\
$8-20-89$ & 13.6 & 6.3 & 16.6 & 9.9 & 16.3 & 25.4 & 11.8 \\
$8-24-89$ & 13.6 & 6.3 & 16.1 & 10.0 & 16.0 & 26.0 & 12.0 \\
$9-22-89$ & 13.9 & 6.0 & 16.2 & 9.4 & 16.2 & 26.2 & 12.0 \\
$10-05-89$ & 14.9 & 6.3 & 15.9 & 9.8 & 15.9 & 25.2 & 12.0 \\
$10-10-89$ & 19.9 & 5.2 & 18.1 & 10.2 & 15.0 & 21.8 & 9.7 \\
$10-24-89$ & 14.1 & 5.6 & 17.2 & 10.0 & 16.8 & 25.0 & 11.3 \\
$10-29-89$ & 14.1 & 5.9 & 15.7 & 9.5 & 16.3 & 25.4 & 12.9 \\
$11-06-89$ & 15.0 & 4.9 & 16.8 & 9.6 & 16.5 & 26.0 & 11.2
\end{tabular}


TABLE 14

PROTON DISTRIBUTION OF V-1067 DISTILLATE SAMPIES

Wilsonville Run 258

\begin{tabular}{cccccccc} 
& \multicolumn{8}{c}{ Proton Distribution, $\%$} \\
Date & $\begin{array}{c}\text { Cond } \\
\text { Arom }\end{array}$ & $\begin{array}{c}\text { Uncond } \\
\text { Arom }\end{array}$ & $\begin{array}{c}\text { Cyclic } \\
\text { Alpha }\end{array}$ & $\begin{array}{c}\text { Alky1 } \\
\text { Alpha }\end{array}$ & $\begin{array}{c}\text { Cyclic } \\
\text { Beta }\end{array}$ & $\begin{array}{c}\text { Alky } \\
\text { Beta }\end{array}$ & Gamma \\
\cline { 2 - 7 } $6-18-89$ & 11.5 & 4.6 & 16.7 & 9.6 & 18.8 & 26.5 & 12.3 \\
$6-28-89$ & 10.6 & 4.8 & 16.7 & 9.7 & 19.6 & 26.3 & 12.4 \\
$7-06-89$ & 12.3 & 4.7 & 17.0 & 9.9 & 18.0 & 26.2 & 11.9 \\
$7-11-89$ & 12.5 & 5.6 & 16.0 & 9.9 & 17.4 & 26.5 & 12.1 \\
$8-10-89$ & 14.2 & 6.3 & 16.4 & 9.6 & 16.3 & 25.1 & 12.2 \\
$8-20-89$ & 14.2 & 5.9 & 16.5 & 9.9 & 16.3 & 25.6 & 11.6 \\
$8-24-89$ & 15.8 & 5.8 & 15.3 & 10.0 & 15.4 & 25.7 & 12.0 \\
$9-20-39$ & 13.3 & 4.1 & 14.4 & 9.7 & 15.7 & 28.0 & 14.6 \\
$10-05-89$ & 14.9 & 6.4 & 15.8 & 9.9 & 15.7 & 24.9 & 12.2 \\
$10-10-89$ & 21.0 & 5.7 & 18.3 & 10.2 & 15.0 & 20.9 & 8.9 \\
$10-23-89$ & 14.7 & 5.5 & 16.7 & 9.6 & 16.7 & 25.0 & 11.7 \\
$10-29-89$ & 13.9 & 6.0 & 15.3 & 9.7 & 16.3 & 25.6 & 13.1 \\
$11-05-89$ & 15.9 & 5.1 & 16.7 & 9.3 & 16.7 & 25.1 & 11.1
\end{tabular}


TABLE 15

PROTON DISTRIBUTION OF R-1235 DISTILLATE SAMPLES

Wilsonville Run 258

\begin{tabular}{cccccccc} 
& \multicolumn{8}{c}{ Proton Distribution, \% } \\
\cline { 2 - 6 } Date & $\begin{array}{c}\text { Cond } \\
\text { Arom }\end{array}$ & $\begin{array}{c}\text { Uncond } \\
\text { Arom }\end{array}$ & $\begin{array}{c}\text { Cyclic } \\
\text { Alpha }\end{array}$ & $\begin{array}{c}\text { Alky1 } \\
\text { Alpha }\end{array}$ & $\begin{array}{c}\text { Cyclic } \\
\text { Beta }\end{array}$ & $\begin{array}{c}\text { Alkyl } \\
\text { Beta }\end{array}$ & Gamma \\
6-18-89 & 13.6 & 9.6 & 14.9 & 10.4 & 14.7 & 24.7 & 12.0 \\
$6-28-89$ & 12.9 & 6.5 & 15.8 & 10.8 & 16.0 & 25.6 & 12.4 \\
$7-06-89$ & 13.5 & 7.0 & 15.6 & 11.1 & 15.5 & 25.1 & 12.1 \\
$7-15-89$ & 15.7 & 6.3 & 16.0 & 11.1 & 14.3 & 24.8 & 11.8 \\
8-10-89 & 16.4 & 6.6 & 15.5 & 10.8 & 14.0 & 24.8 & 11.8 \\
8-20-89 & 14.3 & 8.9 & 13.0 & 11.7 & 13.0 & 24.3 & 14.9 \\
8-24-89 & 15.2 & 7.5 & 15.1 & 11.4 & 13.7 & 25.1 & 12.0 \\
$9-21-89$ & 14.9 & 8.1 & 13.3 & 10.6 & 12.5 & 26.8 & 13.9 \\
$10-05-89$ & 19.4 & 7.9 & 15.2 & 10.7 & 12.5 & 23.3 & 11.1 \\
$10-10-89$ & 24.3 & 7.8 & 16.2 & 11.4 & 11.0 & 20.6 & 8.8 \\
$10-24-89$ & 19.7 & 6.9 & 15.3 & 10.8 & 12.4 & 24.0 & 10.8 \\
$10-30-89$ & 19.2 & 8.1 & 14.0 & 11.1 & 11.8 & 23.9 & 11.9 \\
$11-05-89$ & 19.7 & 6.4 & 15.2 & 10.7 & 12.7 & 24.5 & 10.8
\end{tabular}


TABLE 16

PROTON DISTRIBUTION OF $V$-131B RESID SAMPLES

Wilsonville Run 258

\begin{tabular}{|c|c|c|c|c|c|c|c|}
\hline \multirow[b]{2}{*}{ Date } & \multicolumn{7}{|c|}{ Proton Distribution, $\%$} \\
\hline & $\begin{array}{l}\text { Cond } \\
\text { Arom }\end{array}$ & $\begin{array}{l}\text { Uncond } \\
\text { Arom }\end{array}$ & $\begin{array}{l}\text { Cyclic } \\
\text { Alpha }\end{array}$ & $\begin{array}{l}\text { Alkyl } \\
\text { Alpha }\end{array}$ & $\begin{array}{c}\text { Cyclic } \\
\text { Beta }\end{array}$ & $\begin{array}{l}\text { Alkyt } \\
\text { Beta } \\
\end{array}$ & Gamma \\
\hline $6-18-89$ & 27.7 & 3.6 & 20.7 & 9.2 & 14.7 & 15.7 & 8.3 \\
\hline $6-28-89$ & 26.6 & 4.7 & 20.2 & 9.7 & 14.5 & 15.5 & 8.8 \\
\hline $7-06-8.9$ & 30.7 & 4.9 & 21.9 & 9.9 & 13.5 & 12.5 & 6.6 \\
\hline $7-14-89$ & 31.2 & 4.8 & 21.0 & 9.5 & 12.4 & 12.3 & 8.7 \\
\hline $8-10-89$ & 33.8 & 5.0 & 20.6 & 9.4 & 12.6 & 11.6 & 6.9 \\
\hline $8-20-89$ & 32.1 & 5.8 & 20.2 & 9.5 & 12.1 & 12.8 & 7.6 \\
\hline $8-24-89$ & 32.7 & 4.4 & 21.1 & 9.3 & 13.0 & 12.0 & 7.5 \\
\hline $9-22-89$ & 33.7 & 3.8 & 21.5 & 9.4 & 12.7 & 12.8 & 6.2 \\
\hline $10-05-89$ & 37.0 & 3.8 & 21.5 & 9.1 & 12.0 & 11.3 & 5.4 \\
\hline $10-10-89$ & 40.2 & 4.1 & 20.8 & 9.7 & 10.2 & 9.7 & 5.4 \\
\hline $10-24-89$ & 34.8 & 3.7 & 21.7 & 9.2 & 12.9 & 11.9 & 5.8 \\
\hline $10-29-89$ & 33.7 & 5.8 & 20.4 & 9.4 & 12.0 & 12.3 & 6.4 \\
\hline $11-06-89$ & 34.9 & 5.2 & 20.8 & 9.2 & 11.8 & 11.2 & 6.9 \\
\hline
\end{tabular}


TABLE 17

PROTON DISTRIBUTION OF V-1067 RESID SAMPLES

Wilsonville Run 258

\begin{tabular}{|c|c|c|c|c|c|c|c|}
\hline \multirow[b]{2}{*}{ Date } & \multicolumn{7}{|c|}{ Proton Distribution, $\%$} \\
\hline & $\begin{array}{l}\text { Cond } \\
\text { Arom }\end{array}$ & $\begin{array}{l}\text { Uncond } \\
\text { Arom }\end{array}$ & $\begin{array}{l}\text { Cyclic } \\
\text { Alpha }\end{array}$ & $\begin{array}{l}\text { Alkyl } \\
\text { Alpha }\end{array}$ & $\begin{array}{l}\text { Cycl ic } \\
\text { Beta }\end{array}$ & $\begin{array}{l}\text { Alkyl } \\
\text { Beta } \\
\end{array}$ & Gamma \\
\hline $6-18-89$ & 29.3 & 3.9 & 22.8 & 9.3 & 13.9 & 13.7 & 7.1 \\
\hline $6-28-89$ & 28.0 & 4.0 & 23.3 & 9.7 & 14.6 & 14.2 & 6.3 \\
\hline $7-06-89$ & 29.7 & 4.6 & 22.9 & 9.3 & 13.4 & 12.8 & 7.3 \\
\hline $7-11-89$ & 31.8 & 4.0 & 23.0 & 9.4 & 12.8 & 12.4 & 6.5 \\
\hline $8-10-89$ & 32.7 & 5.4 & 22.1 & 9.0 & 12.7 & 11.6 & 6.6 \\
\hline $8-20-89$ & 32.4 & 5.0 & 21.4 & 9.5 & 12.4 & 12.5 & 6.7 \\
\hline $8-24-89$ & 32.2 & 5.0 & 21.5 & 9.4 & 12.9 & 12.6 & 6.3 \\
\hline $9-20-89$ & 33.1 & 4.0 & 21.7 & 9.5 & 12.7 & 13.0 & 6.0 \\
\hline $10-05-89$ & 36.8 & 4.6 & 20.7 & 9.5 & 11.9 & 10.9 & 5.7 \\
\hline $10-10-89$ & 42.8 & 4.0 & 21.2 & 9.1 & 10.6 & 8.4 & 4.0 \\
\hline $10-23-89$ & 34.5 & 4.8 & 20.9 & 9.2 & 12.6 & 11.7 & 6.3 \\
\hline $10-29-89$ & 34.9 & 4.8 & 21.9 & 9.3 & 12.2 & 11.3 & 5.6 \\
\hline $11-05-89$ & 36.1 & 4.0 & 21.4 & 9.3 & 11.9 & 11.7 & 5.5 \\
\hline
\end{tabular}


TABLE 18

PROTON DISTRIBUTION OF R-1235 RESID SAMPLES

Wilsonville Run 258

\begin{tabular}{|c|c|c|c|c|c|c|c|}
\hline \multirow[b]{2}{*}{ Date } & \multicolumn{7}{|c|}{ Proton Distribution, $\%$} \\
\hline & $\begin{array}{l}\text { Cond } \\
\text { Arom }\end{array}$ & $\begin{array}{l}\text { Uncond } \\
\text { Arom }\end{array}$ & $\begin{array}{l}\text { Cyclic } \\
\text { Alpha }\end{array}$ & $\begin{array}{l}\text { Alkyl } \\
\text { Alpha }\end{array}$ & $\begin{array}{l}\text { Cyclic } \\
\text { Beta }\end{array}$ & $\begin{array}{l}\text { Alkyl } \\
\text { Beta } \\
\end{array}$ & Gamma \\
\hline $6-18-89$ & 28.3 & 4.6 & 21.0 & 9.1 & 13.9 & 15.0 & 8.2 \\
\hline $6-28-89$ & 30.7 & 4.1 & 22.2 & 9.8 & 12.9 & 13.6 & 6.7 \\
\hline $7-06-89$ & 31.9 & 6.1 & 20.2 & 10.0 & 12.1 & 12.7 & 7.1 \\
\hline $7-15-89$ & 32.5 & 6.3 & 20.2 & 10.0 & 12.1 & 11.8 & 7.0 \\
\hline $8-10-89$ & 34.2 & 6.1 & 20.1 & 9.7 & 11.5 & 11.5 & 7.0 \\
\hline $8-20-89$ & 35.4 & 5.6 & 2.0 .9 & 10.0 & 11.8 & 9.4 & 6.8 \\
\hline $8-24-89$ & 35.5 & 5.1 & 20.9 & 9.6 & 11.3 & 11.5 & 6.2 \\
\hline $9-21-89$ & 35.6 & 4.7 & 21.3 & 9.4 & 11.2 & 12.0 & 5.6 \\
\hline $10-05-89$ & 40.5 & 5.3 & 20.2 & 9.2 & 10.1 & 9.4 & 5.3 \\
\hline $10-10-89$ & 45.1 & 4.9 & 19.8 & 8.9 & 8.8 & 8.2 & 4.3 \\
\hline $10-24-89$ & 37.7 & 7.3 & 19.4 & 9.4 & 10.0 & 10.5 & 5.7 \\
\hline $10-30-89$ & 38.2 & 8.7 & 18.7 & 9.3 & 9.7 & 10.0 & 5.3 \\
\hline $11-05-89$ & 39.2 & 5.7 & 21.1 & 9.1 & 9.6 & 10.6 & 4.7 \\
\hline
\end{tabular}


TABLE 19

PHENOL CONCENTRATION BY FTIR Wilsonville Run 258

Phenolic $-\mathrm{OH}$ Concentrations, meq/g

\begin{tabular}{|c|c|c|c|c|c|c|}
\hline \multirow[b]{2}{*}{ Date } & \multicolumn{2}{|c|}{$V-131 B$} & \multicolumn{2}{|c|}{$V-1067$} & \multicolumn{2}{|c|}{$R-1235$} \\
\hline & Dist & Resid & Dist & Resid & Dist & Resid \\
\hline $\begin{array}{l}6-18-89 \\
6-28-89 \\
7-06-89 \\
7-11-89\end{array}$ & $\begin{array}{l}0.41 \\
0.40 \\
0.50\end{array}$ & $\begin{array}{l}0.80 \\
0.88 \\
0.95 \\
-\end{array}$ & $\begin{array}{l}0.40 \\
0.41 \\
0.47 \\
0.49\end{array}$ & $\begin{array}{l}0.83 \\
0.90 \\
0.94 \\
0.96\end{array}$ & $\begin{array}{l}1.06 \\
1.06 \\
1.12\end{array}$ & $\begin{array}{l}1.05 \\
1.13 \\
1.13\end{array}$ \\
\hline $7-14-89$ & 0.52 & 0.99 & - & - & - & - \\
\hline $7-15-89$ & - & - & - & - & 1.09 & 1.18 \\
\hline $8-10-89$ & 0.56 & 0.88 & 0.56 & 0.91 & 1.09 & 1.18 \\
\hline $8-20-89$ & 0.64 & 0.93 & 0.68 & 0.93 & 1.16 & 1.08 \\
\hline $8-24-89$ & 0.66 & 1.01 & 0.69 & 0.98 & 1.20 & 1.16 \\
\hline $9-20-89$ & - & - & 0.57 & 0.98 & - & - \\
\hline $9-21-89$ & - & - & - & - & 1.13 & 1.18 \\
\hline $9-22-89$ & 0.57 & 0.93 & - & - & - & - \\
\hline $10-05-89$ & 0.46 & 0.80 & 0.46 & 0.76 & 1.09 & 1.07 \\
\hline $10-10-89$ & 0.53 & 0.83 & 0.53 & 0.84 & 1.13 & 1.07 \\
\hline $10-23-89$ & - & - & 0.36 & 0.73 & - & - \\
\hline $10-24-89$ & 0.36 & 0.72 & - & - & 1.03 & 1.02 \\
\hline $10-29-89$ & 0.36 & 0.80 & 0.36 & 0.84 & - & - \\
\hline $10-30-89$ & - & - & - & - & 0.98 & 1.06 \\
\hline $11-05-8$ & 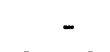 & $n$ & 0.35 & 0.80 & 1.00 & 1.11 \\
\hline $11-06-89$ & 0.39 & 0.78 & - & - & - & - \\
\hline
\end{tabular}

Peak maxima between 3302 and $3312 \mathrm{~cm}^{-1}$ for all distillates and between 3292 and $3303 \mathrm{~cm}^{-1}$ for all resids. 
TABLE 20

\section{MICROAUTOCLAVE TEST RESULTS} Wilsonville Run 258

Date

$6-18-89$

$6-28-89$

$7-06-89$

$7-11-89$

$7-14-89$

$7-15-89$

$8-10-89$

$8-20-89$

$8-24-89$

$9-20-89$

$9-21-89$

$9-22-89$

$10-05-89$

$10-10-89$

$10-23-89$

$10-24-89$

$10-29-89$

$10-30-89$

$11-05-89$

$11-06-89$
Mic

Dist $\quad$ R-131B

Resid

\section{0}

82.1

83.6

80.2

46.1

78.4

83.2

84.7

85.0

83.2

$-$

85.4

86.2

87.6

89.1

88.6

$-$

85.1
72.

72.8

48.4

73.4

68.0

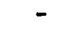

70.7

58.6

61.4

76.9

75.8

68.9

\section{V-1067

Dist

84.2

82.5

83.2

83.5

$-$

85.5

84.5

82.8

85.2

$-$

86.6

88.2

90.4

89.2

86.6
Resid

44.6

80.7

75.6

77.4

$-$

75.4

64.8

43.5

68.1<smiles>[SiH3]</smiles>

57.0

51.4

61.8

52.6

60.6

\section{$\%$ MAF Coal)}

$\frac{R-1235}{\text { Dist Resid }}$

\section{4}

76.8

76.5

64.3

51.3

63.9

$-$

78.6

78.0

78.9

80.1

77.7

79.0

76.5

74.9

74.9

75.4

74.9

41.2

40.5 
TABLE 21

CONVERSION OF RESID COMPONENTS

Wilsonville Run 258

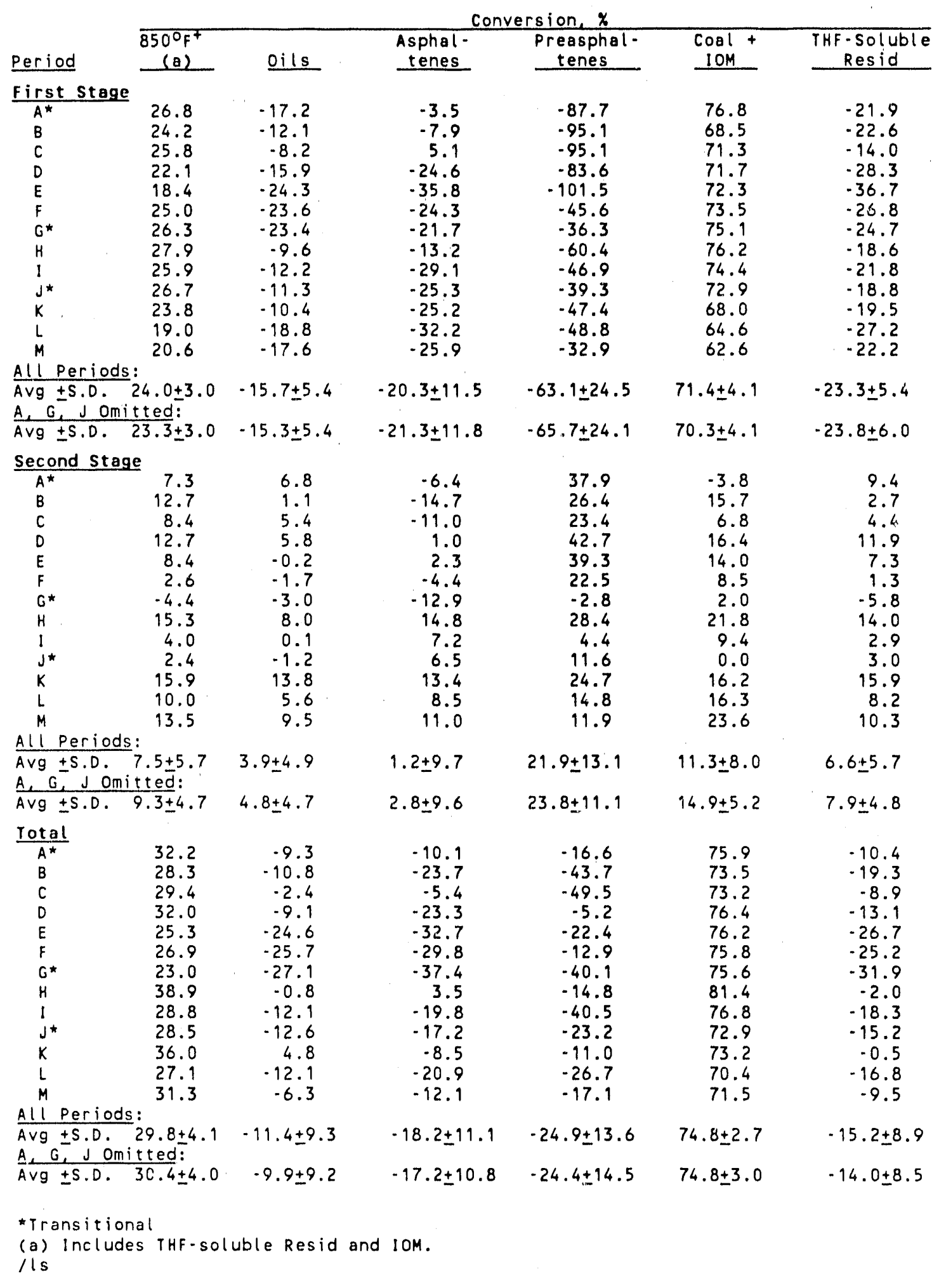


TABLE 22

\section{$850^{\circ} \mathrm{F}+$ CONVERSION AND KINETICS Wilsonville Run 258}

\begin{tabular}{|c|c|}
\hline Period & $\begin{array}{c}\text { Temp. } \\
\mathrm{O}_{\mathrm{F}} \\
\end{array}$ \\
\hline$A^{\star}$ & 843 \\
\hline B & 828 \\
\hline c & 840 \\
\hline D & 840 \\
\hline$E$ & 840 \\
\hline $\mathrm{F}$ & 841 \\
\hline$G^{*}$ & 840 \\
\hline H & 841 \\
\hline 1 & 852 \\
\hline J* & 864 \\
\hline$K$ & 851 \\
\hline L. & 852 \\
\hline$M$ & 852 \\
\hline
\end{tabular}

\begin{tabular}{|c|c|c|}
\hline $\begin{array}{l}\text { Firs } \\
\text { Conve } \\
\text { Consol } \\
\text { (d) }\end{array}$ & $\begin{array}{l}\text { Stage } \\
\text { sion (c) } \\
\text { H'ville } \\
\text { (e) }\end{array}$ & $\begin{array}{c}K \\
(a) \\
\end{array}$ \\
\hline $\begin{array}{l}26.8 \\
24.2 \\
25.8 \\
22.1 \\
18.4 \\
25.0 \\
26.3 \\
27.9 \\
25.9 \\
26.7 \\
23.8 \\
19.0 \\
20.6\end{array}$ & $\begin{array}{l}28.85 \\
23.84 \\
26.68 \\
26.83 \\
29.70 \\
29.96 \\
29.75 \\
27.43 \\
27.55 \\
28.22 \\
24.85 \\
23.84 \\
21.99\end{array}$ & $\begin{array}{l}1.65 \\
1.50 \\
1.64 \\
1.31 \\
0.81 \\
1.23 \\
1.28 \\
1.74 \\
1.50 \\
1.86 \\
1.63 \\
1.22 \\
1.40\end{array}$ \\
\hline
\end{tabular}

\begin{tabular}{|c|c|c|c|}
\hline Period & $\begin{array}{c}\text { Temp. , } \\
\mathrm{O}_{\mathrm{F}}\end{array}$ & $\begin{array}{l}\text { WHSV } \\
\text { (a) }\end{array}$ & $\begin{array}{l}\text { Cat. } \\
\text { Age } \\
\text { (b) }\end{array}$ \\
\hline$A^{*}$ & 739 & 4.5 & 3276 \\
\hline B & 760 & 4.7 & 2604 \\
\hline C & 760 & 4.7 & 2571 \\
\hline D & 790 & 4.6 & 2568 \\
\hline$E$ & 788 & 3.6 & 2392 \\
\hline$F$ & 760 & 3.7 & 2416 \\
\hline$G^{\star}$ & 760 & 3.6 & 2442 \\
\hline$H$ & 790 & 4.5 & 2572 \\
\hline 1 & 790 & 4.3 & 2541 \\
\hline$J^{\star}$ & 790 & 5.1 & 2539 \\
\hline$k$ & 760 & 5.2 & 559 \\
\hline L & 759 & 5.2 & 1130 \\
\hline M & 788 & 5.4 & 1314 \\
\hline
\end{tabular}

Second-Stage Conversion (c) Consol W'ville (d) (e)

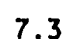

7.3

5.4

4.9

12.7

8.4

2.6

$-4.4$

15.3

4.0

2.4

15.9

10.0

13.5

8.10

11.35

8.08

9.71

9.90

7.21

7.55

14.61

14.82

12.38

13.23

12.56

15.02

\section{$K$}

(a)

0.36

0.27

0.24

0.67

0.33

0.10

$-0.15$

0.81

0.18

0.13

0.99

0.58

0.84
A. 7

(a)

1.84

1.03

0.92

1.67

0.85

0.37

$-0.58$

2.03

0.45

0.32

3.75

2.22

2.16
Iotal Conversion

Consol W'ville (d) (e)

32.2

28.3

29.4

32.0

25.3

26.9

23.0

38.9

28.8

28.5

36.0

27.1

31.3
34.6

32.5

32.6

33.9

36.7

35.0

35.1

38.0

38.3

37.1

34.8

33.4

33.7
Ratio Consol/W'ville Stage Stage 1 2 Total $\begin{array}{lll}0.928 & 0.907 & 0.929\end{array}$ $\begin{array}{lll}1.015 & 0.479 & 0.872\end{array}$ $\begin{array}{lll}0.968 & 0.603 & 0.903\end{array}$ $\begin{array}{lll}0.826 & 1.308 & 0.944\end{array}$ $\begin{array}{lll}0.621 & 0.852 & 0.691\end{array}$ $\begin{array}{llll}0.834 & 0.357 & 0.769\end{array}$ $\begin{array}{llll}0.883 & -0.587 & 0.656\end{array}$ $\begin{array}{llll}1.017 & 1.045 & 1.023\end{array}$ $0.939 \quad 0.279 \quad 0.753$ $\begin{array}{llll}0.948 & 0.197 & 0.769\end{array}$ $\begin{array}{llll}0.958 & 1.204 & 1.033\end{array}$ $\begin{array}{lll}0.797 & 0.793 & 0.810\end{array}$ $\begin{array}{llll}0.937 & 0.898 & 0.929\end{array}$

\section{Stage 1:}

Average (All Periods)

\pm std. Dev.

$\begin{array}{rrrr}24.0 & 26.9 & 1.44 & 1.76 \\ 3.0 & 2.5 & 0.27 & 0.33 \\ 23.3 & 26.3 & 1.40 & 1.74 \\ 3.0 & 2.5 & 0.26 & 0.37\end{array}$

0.898

0.104

0.891

Average ( $A, G, J$ Omitted)

3.0

2.

$\begin{array}{rrrr}7.5 & 11.1 & 0.41 & 1.31 \\ 5.7 & 2.8 & 0.33 & 1.08 \\ & & & \\ 9.3 & 11.6 & 0.50 & 1.55 \\ 4.7 & 2.7 & 0.30 & 0.98\end{array}$

29.8

4.1

35.1

0.116

Stage 2 and Total:

Average (All Periods)

\pm Std. Dev.

Average ( $A, G, J$ Omitted)

\pm Std. Dev.

* Transitional

\footnotetext{
(a) Ib Total Feed/hr/lb Catalyst

(b) Ib Coal + Resid + Uc/lb Catalyst

(c) First stage and Total Conversion: wt $\chi$ Resid + MAF Coal + UC Fed to first stage Second stage Conversion: Wt $\%$ Resid $+U C$ fed to Second stage

(d) $850^{\circ} \mathrm{F}$ Distillation End Point, atm Equivalent

(e) $1050^{\circ} \mathrm{F}$ Distillation End Point, atm Equivalent 
TABLE 23

COMPARISON OF WILSONVILIE RUNS 251-II AND 258 Operating Conditions

\begin{tabular}{|c|c|c|c|}
\hline & $251-I I$ & & n 258 \\
\hline & Periods A-D & Periods $A-G$ & Periods $\mathrm{H}-\mathrm{M}$ \\
\hline Coal & Clovis Point & Spring Creek & Black Thunder \\
\hline $\begin{array}{l}\% \text { of Available Volume } \\
\text { in Botli Reactors }\end{array}$ & 100 & 50 & 50 \\
\hline $\begin{array}{l}\text { Coal Conc. in Slurry, } \\
\text { wt \% MF }\end{array}$ & 33 & 30 & 30 \\
\hline $\begin{array}{l}\text { Resid in Recycle Solvent, } \\
\text { wt } \%\end{array}$ & 25 & 41 & 41 \\
\hline CI in Recycle Solvent, wt \% & 24 & $20-25$ & 20 \\
\hline Interstage Separator & Yes & Yes & Yes \\
\hline Disposable $\mathrm{Fe}_{2} \mathrm{O}_{3}$ & Yes & Yes & Yes \\
\hline $\mathrm{T}_{1},{ }^{\circ} \mathrm{F}$ & $807-819$ & $828-841$ & $841-864$ \\
\hline $\mathrm{T}_{2},{ }^{\circ} \mathrm{F}$ & $719-747$ & $739-790$ & $759-790$ \\
\hline Catalyst & Amocat 1C & Shel1 324 & She11 324 \\
\hline $\begin{array}{l}\text { Cat. Age, Ib (Resid }+ \\
\text { CI)/1b Cat. }\end{array}$ & $725-1443$ & $2392-3452$ & $415-2572$ \\
\hline WHSV, Ib Feed/1b Cat.-hr & $2.0-2.9$ & $3.6-4.7$ & $4.3-5.2$ \\
\hline Note: All runs thermal/cat & talytic. & & \\
\hline & & & \\
\hline
\end{tabular}


TABLE 24

\section{COMPARISON OF WILSONVILLE RUNS 251-II AND 258 Process 0 il Characteristics, Conversions and Kinetic Constants}

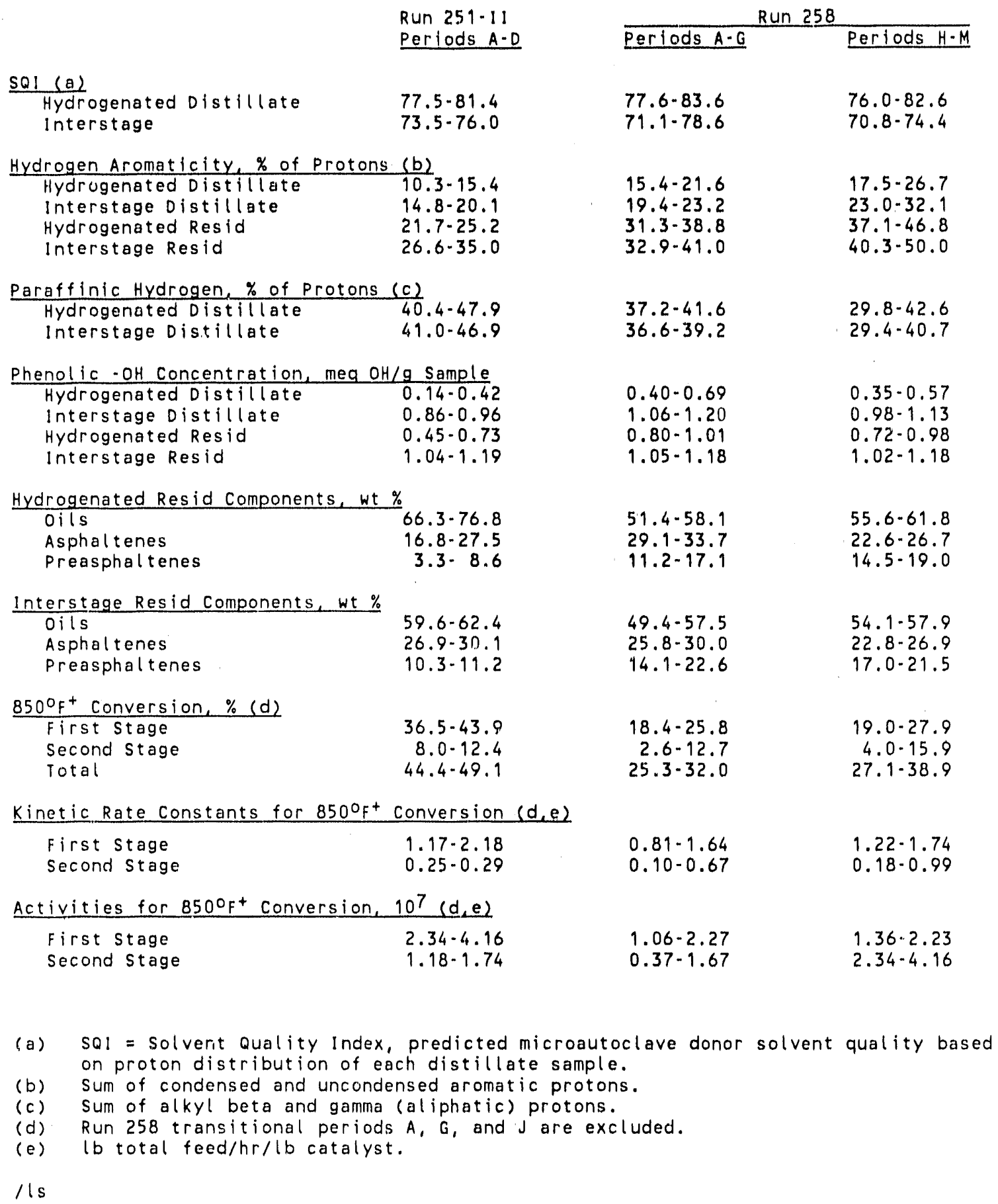




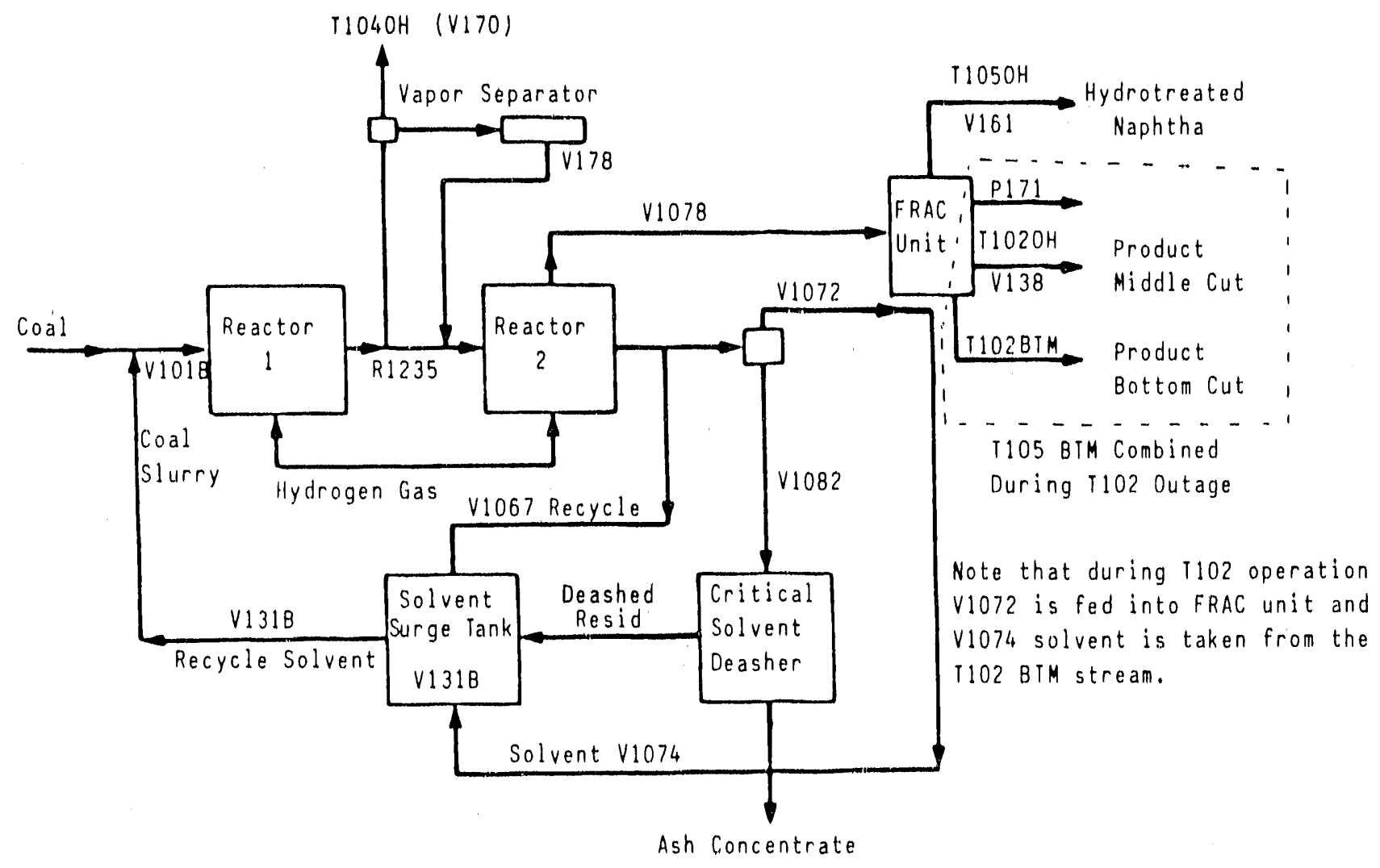

Figure 1. Simplified CC-ITSL Process Diagram for Wilsonville Run 258 (Modified from Reference 4). 


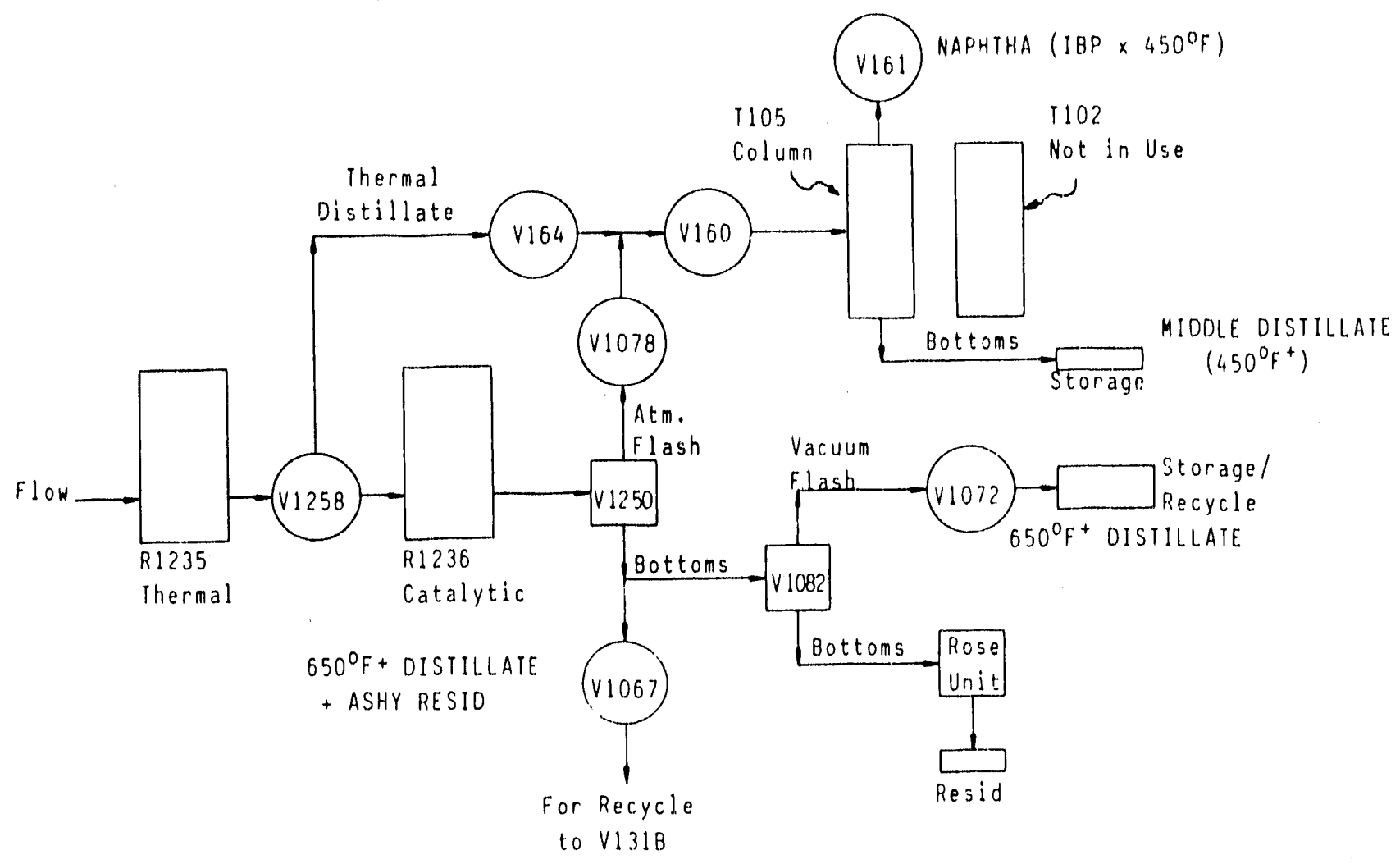

Figure 2. Partial CC-ITSL Process Diagram for Wilsonville Run 258 Showing Major Distillate Streams (Modified from Reference 3 ). 


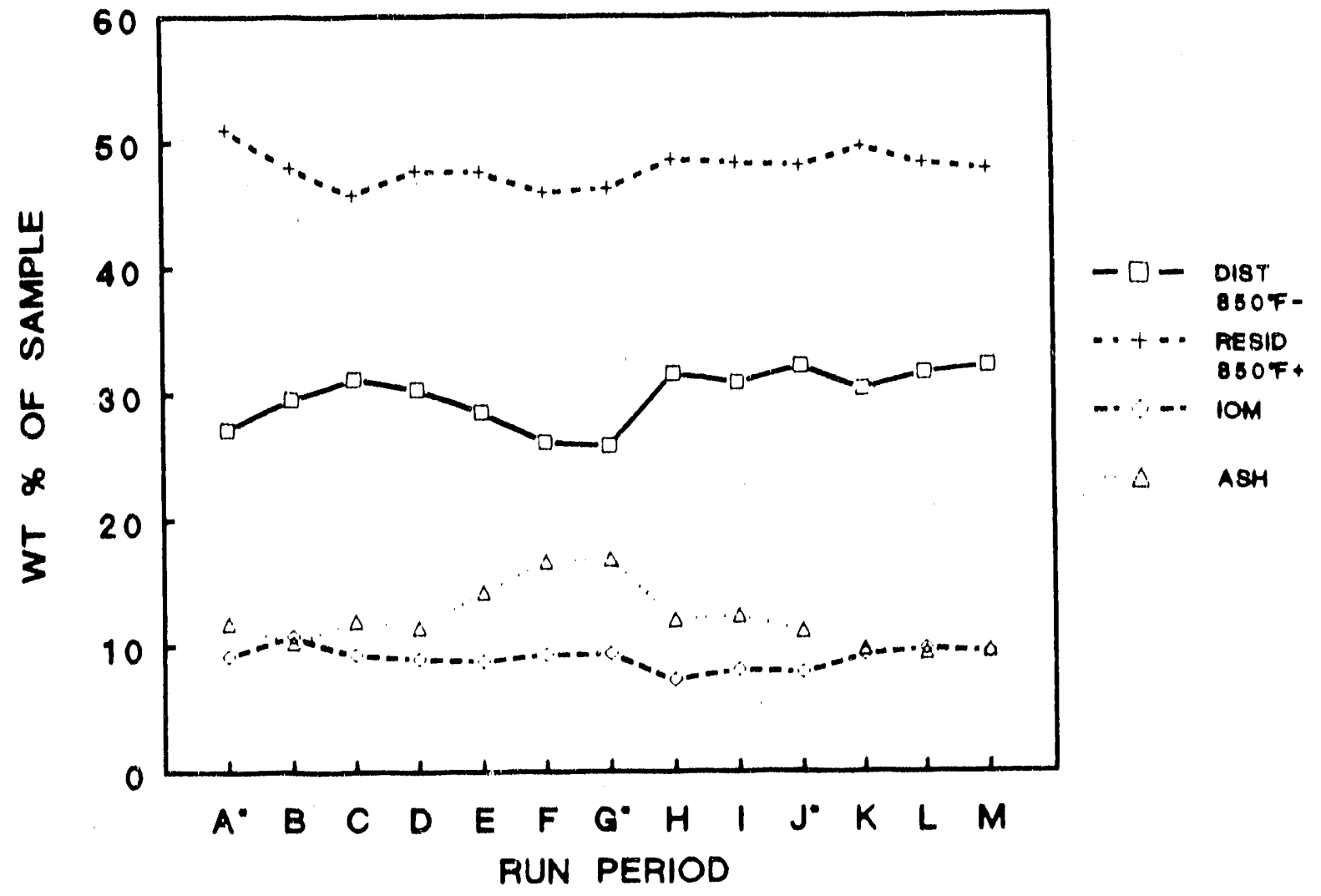

Figure 3. Component Distribution of Whole V-131B 0ils from Wilsonville Run 258. 


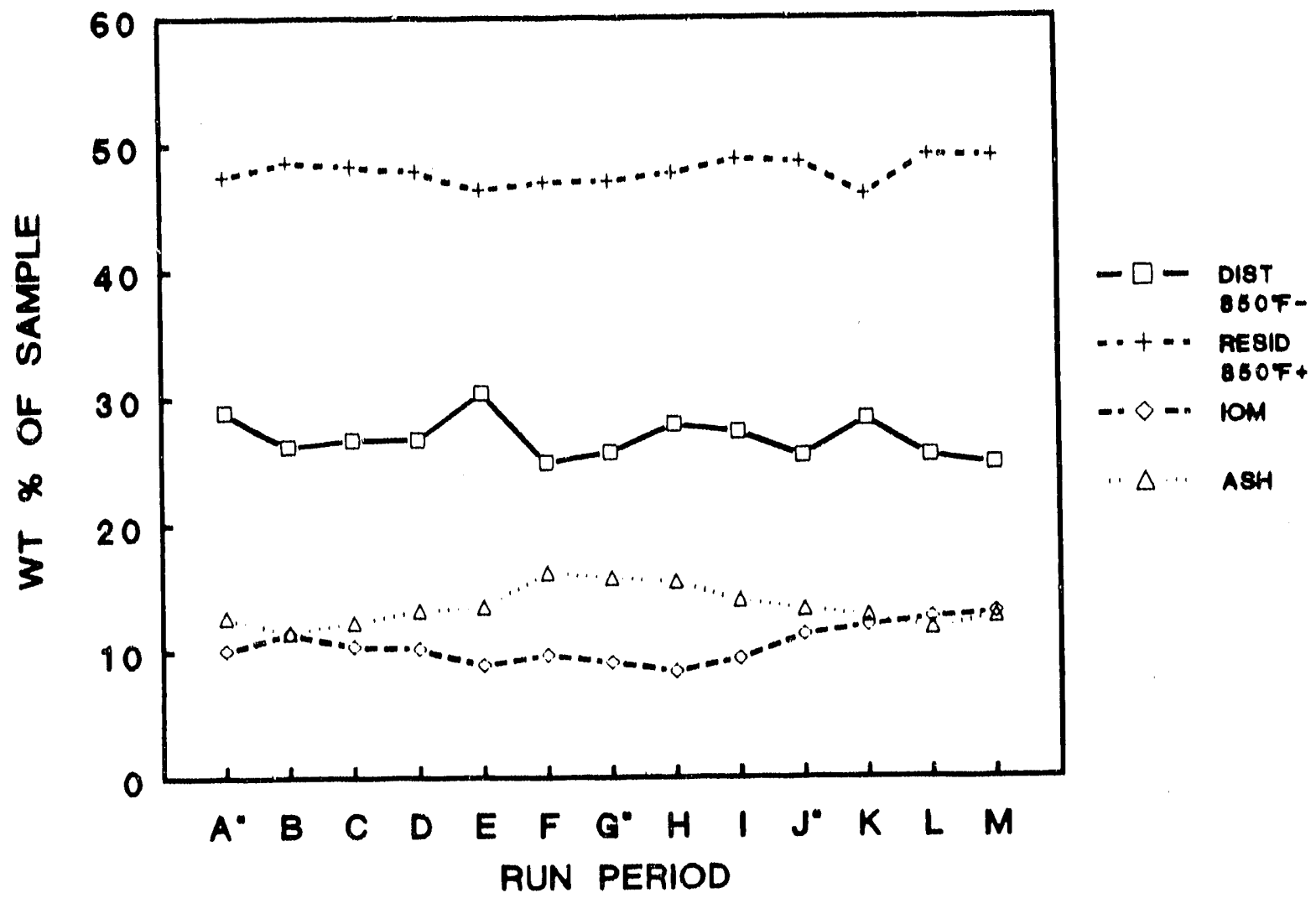

Figure 4. Component Distribution of Whole V-1067 $011 \mathrm{~s}$ from Wilsonville Run 258. 


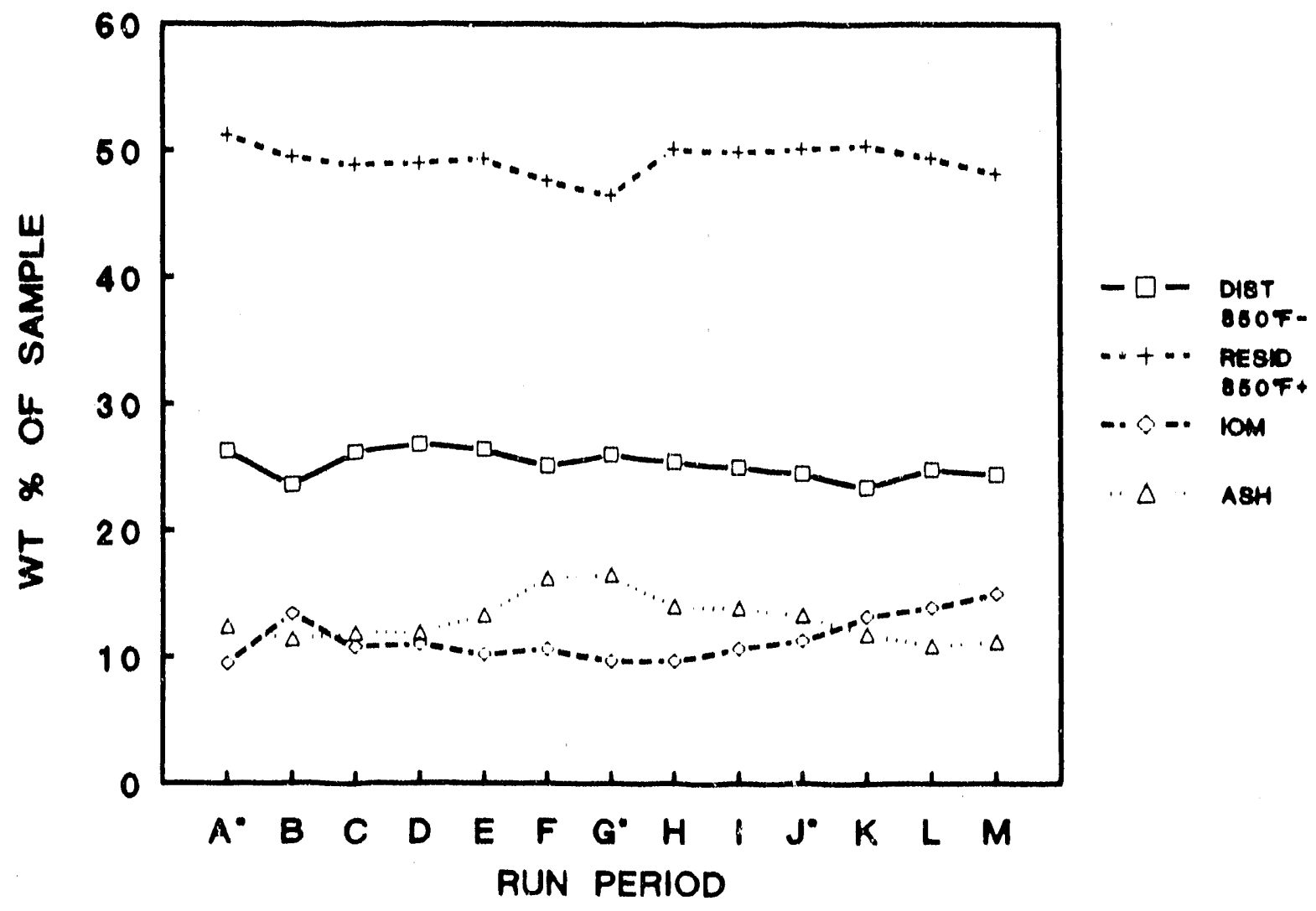

Figure 5. Component Distribution of Whole R-1235 $011 \mathrm{~s}$ from Wilsonville Ruri 258. 


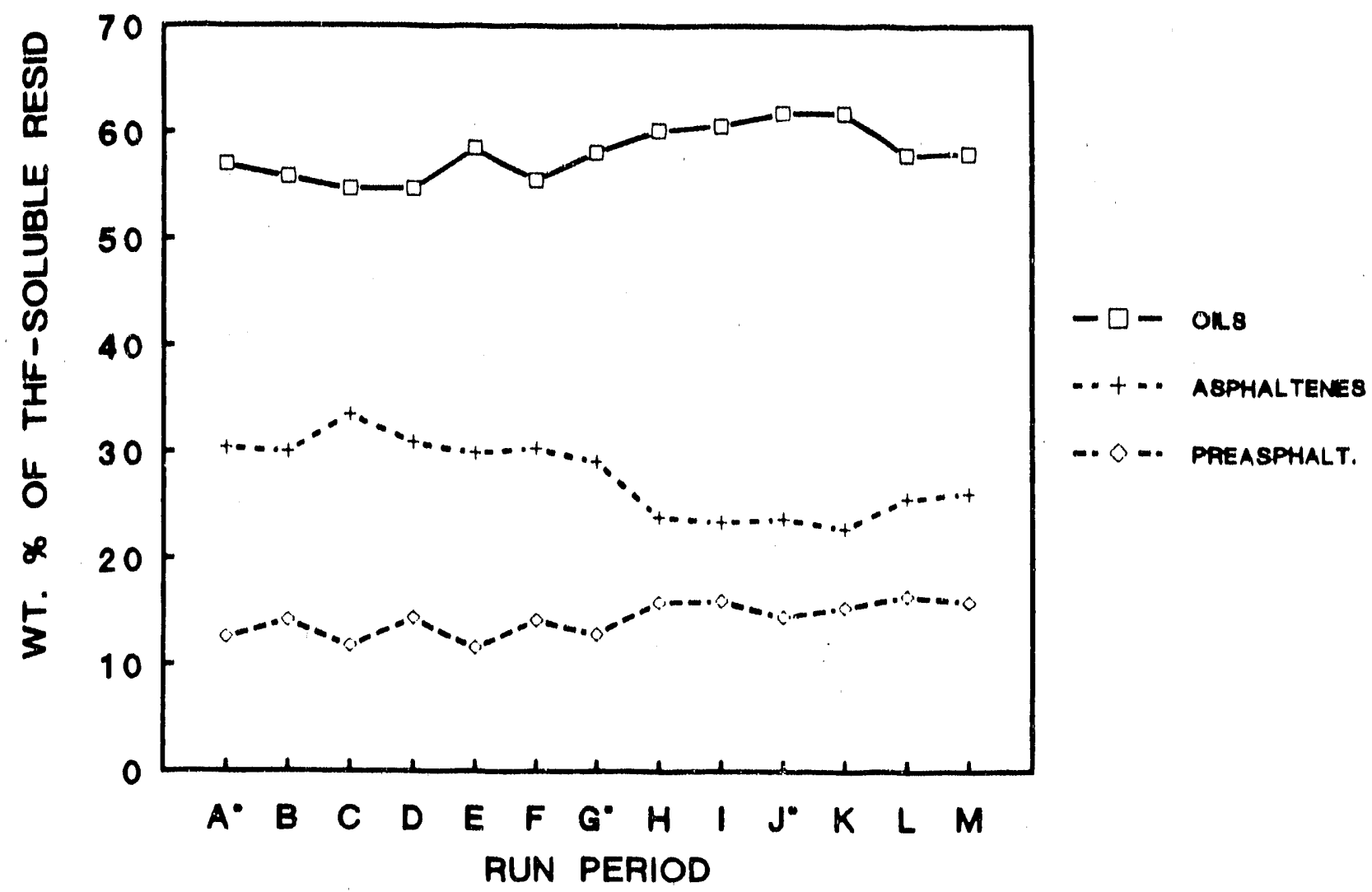

Figure 6. Solubility Fractionation of V-131B THF-Soluble $850^{\circ} \mathrm{F}+$ Resid Samples from Wilsonville Run 258. 


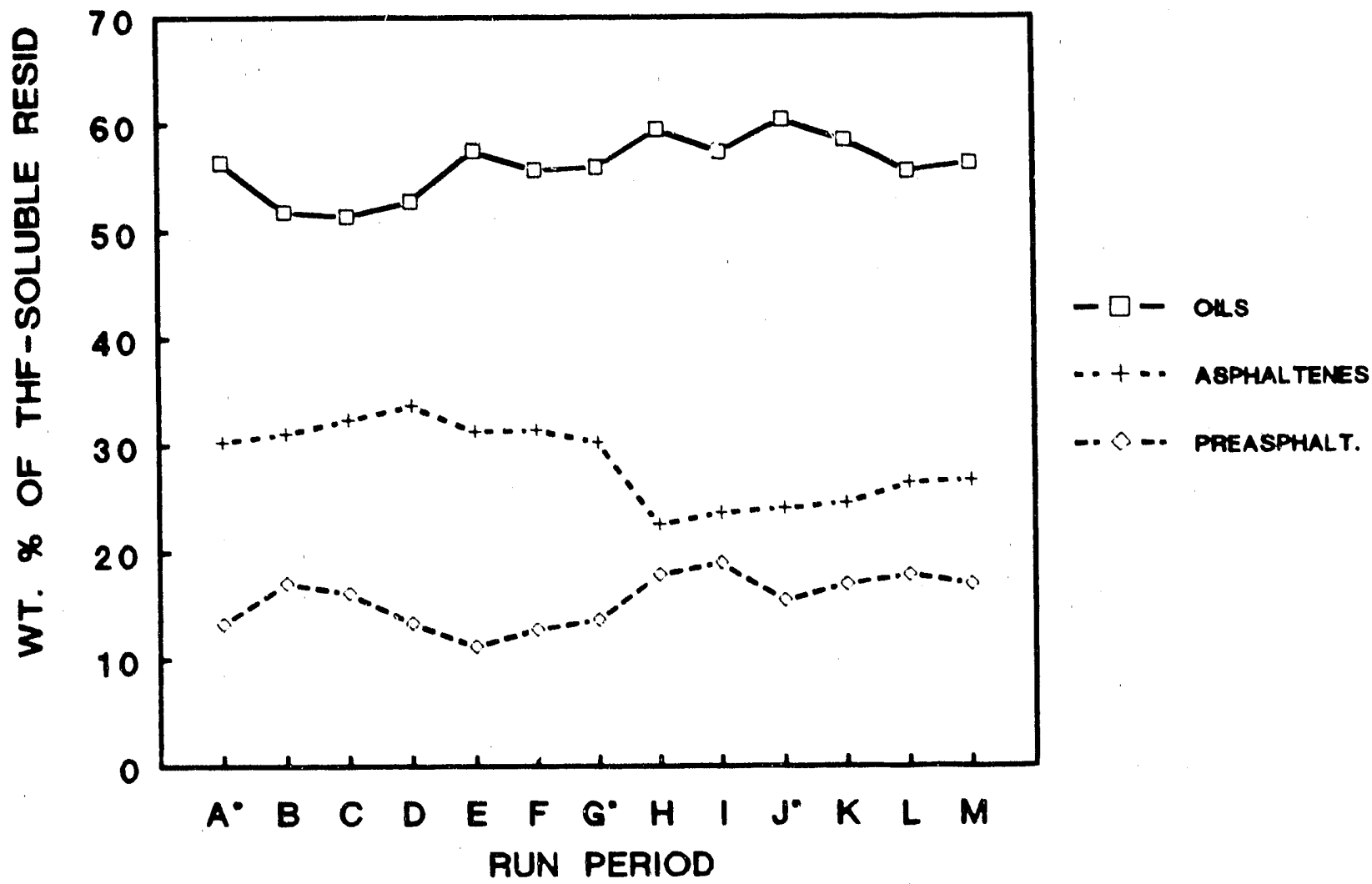

Figure 7. Solubility Fractionation of V-1067 THF-Soluble $850^{\circ} \mathrm{F}+$ Resid Sampies from wiisonviiie Run $2 \overline{5} \overline{8}$. 


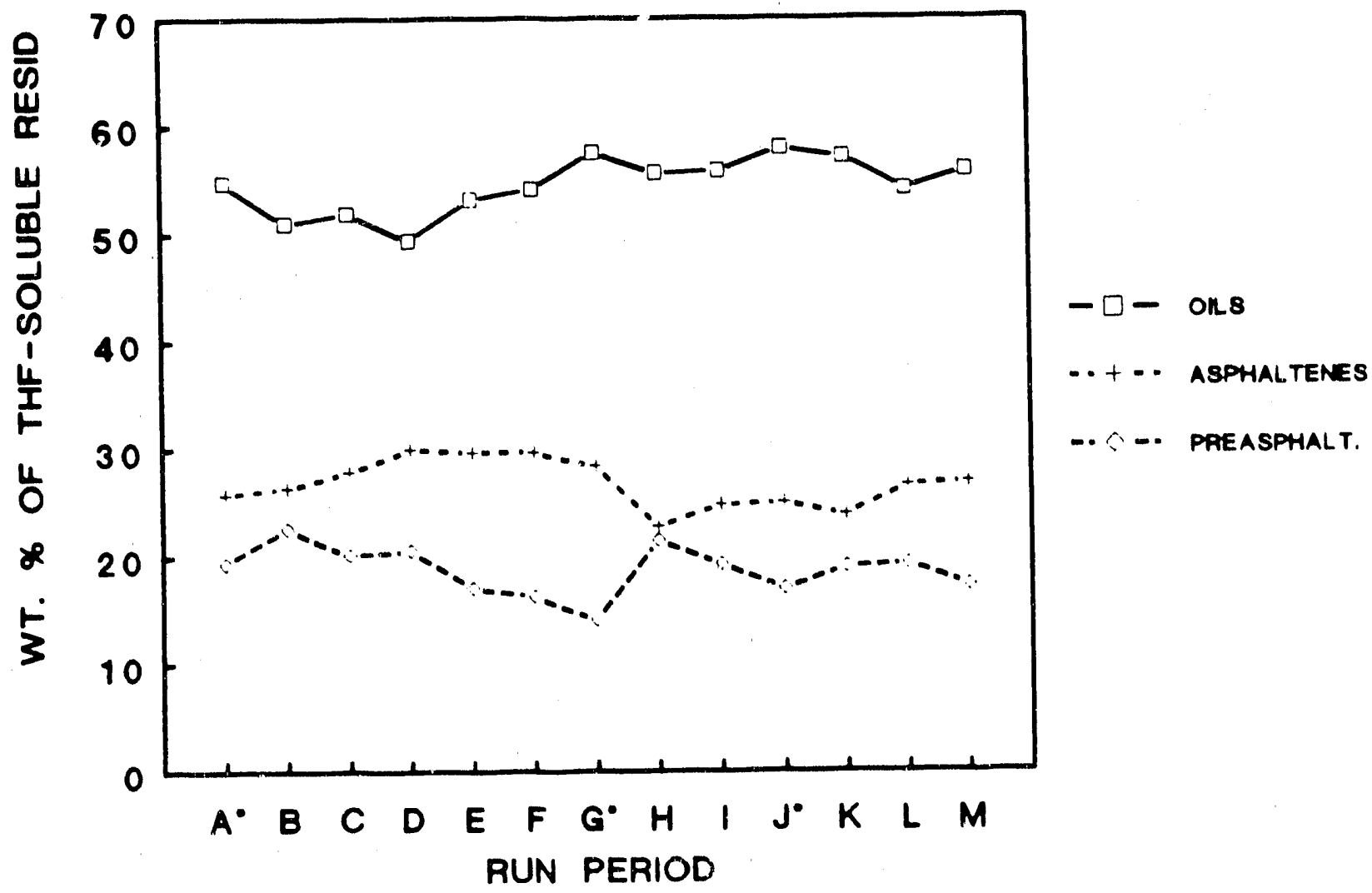

Figure 8. Resid Distribution of R-1235 THF-Soluble $850^{\circ} \mathrm{F}+$ Resid Samples from Wilsonville Run 258. 


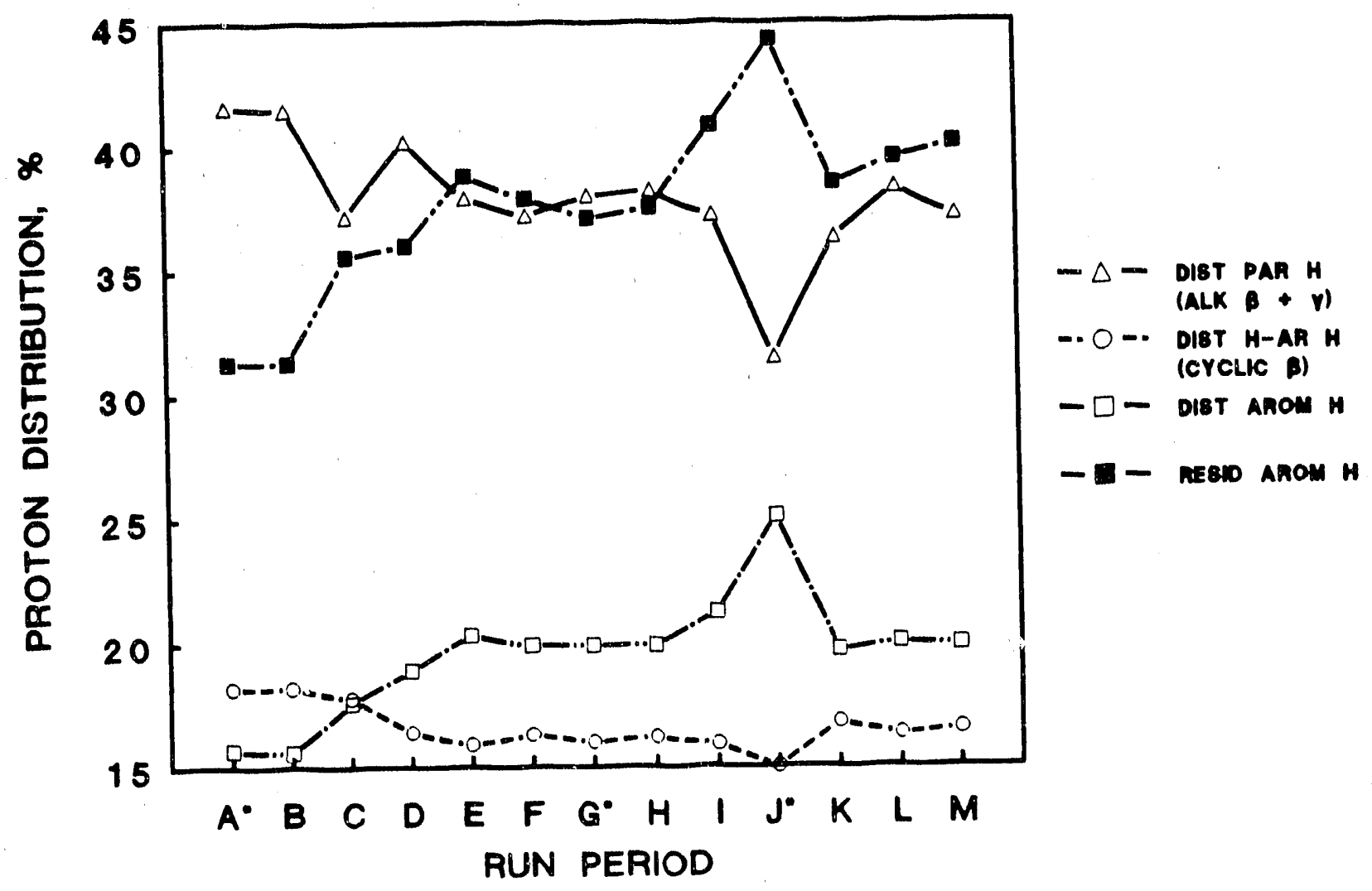

Figure 9. Proton Distribution of V-131B Distillate and THF-Soluble Resid Samples $\left(850^{\circ} \mathrm{F}+\right.$ Cutpoint) from Wilsonville Run 258. 


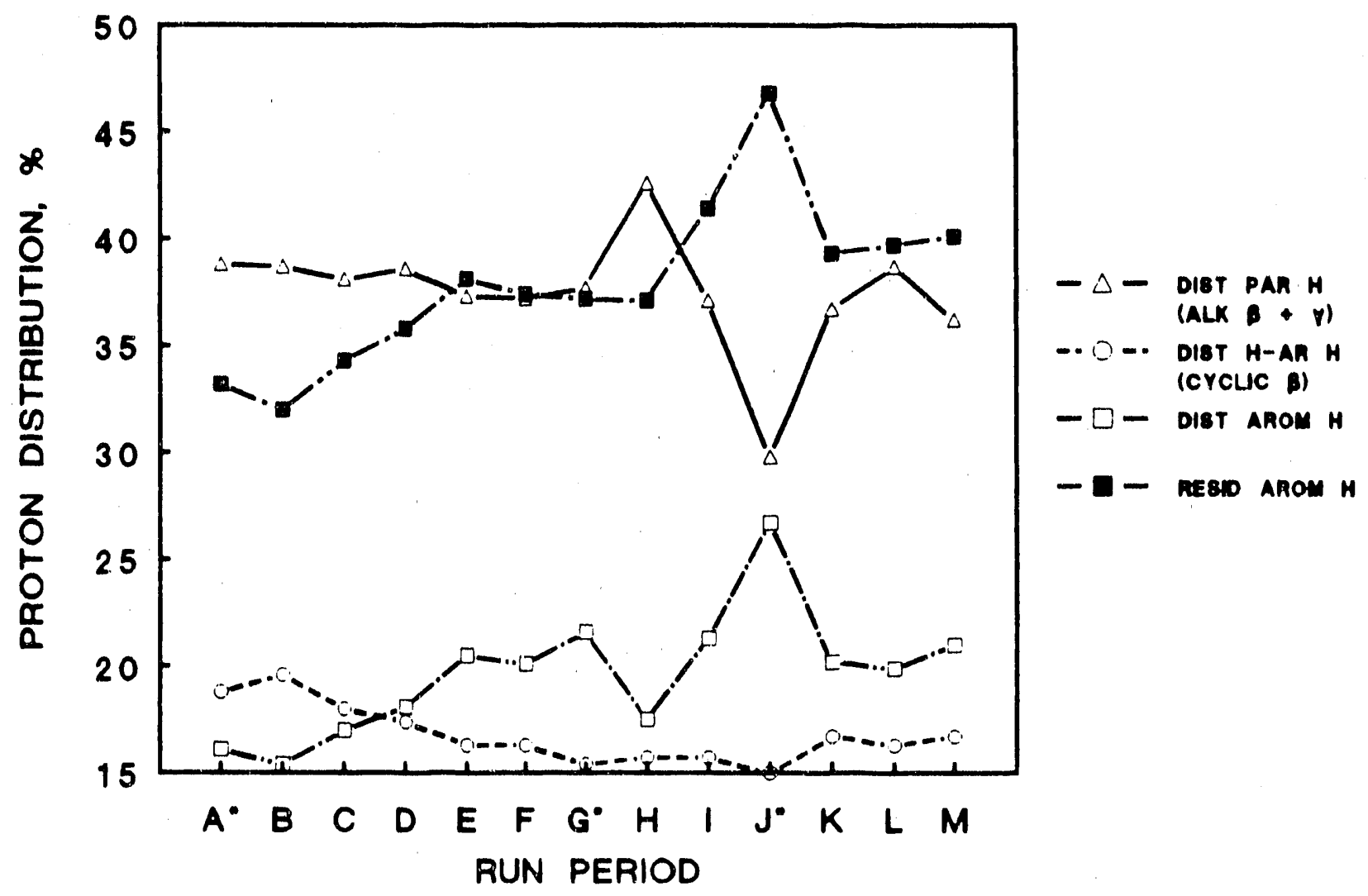

Figure 10. Proton Distribution of V-1067 Distillate and THF-Soluble Resid Samples (850 $\mathrm{F}+$ Cutpoint) from Wilsonville Run 258. 


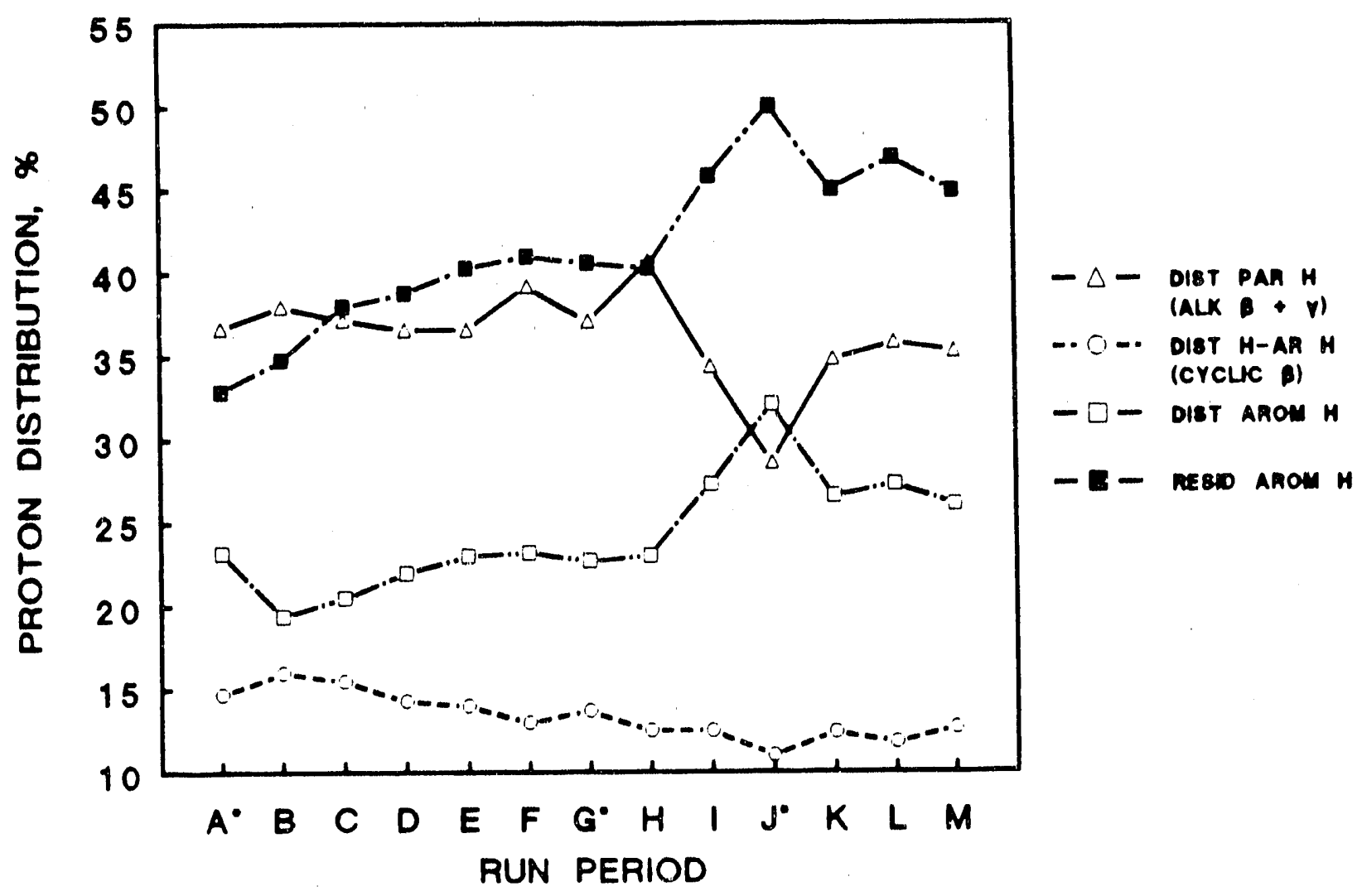

Figure 11. Proton Distribution of R-1235 Distillate and THF-Soluble Resid Samples (850 $\mathrm{F}+$ Cutpoint) from Wilsonville Run 258. 


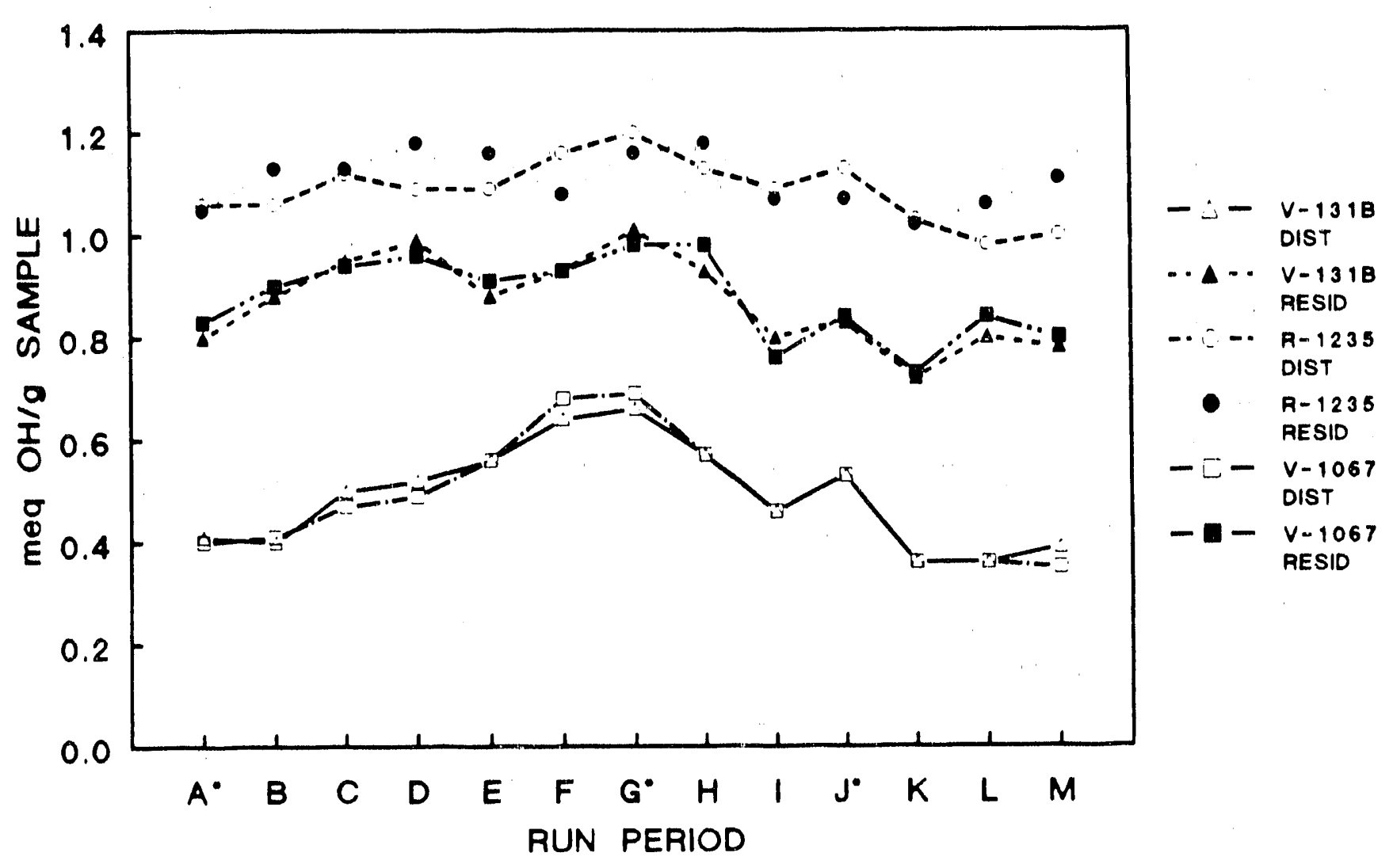

Figure 12. Phenolic $-\mathrm{OH}$ Concentrations of Distillate and THF-Soluble Resid Samples (850 $\mathrm{F}+$ Cutpoint) from Wilsonville Run 258. 


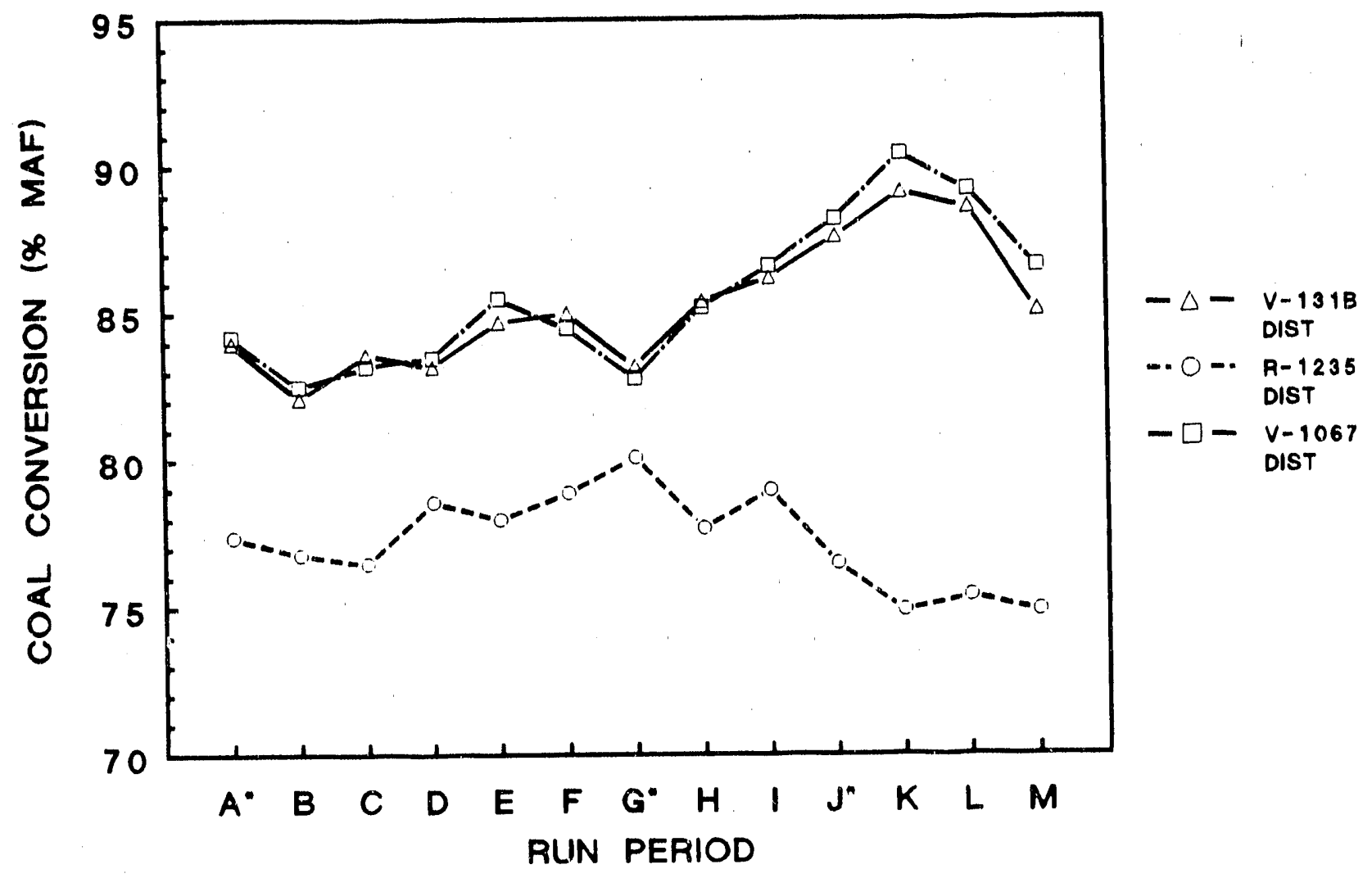

Figure 13. Microautoclave Solvent Quality Assays of $850^{\circ} \mathrm{F}$ Distillate Samples from Wilsonville Run 258. 


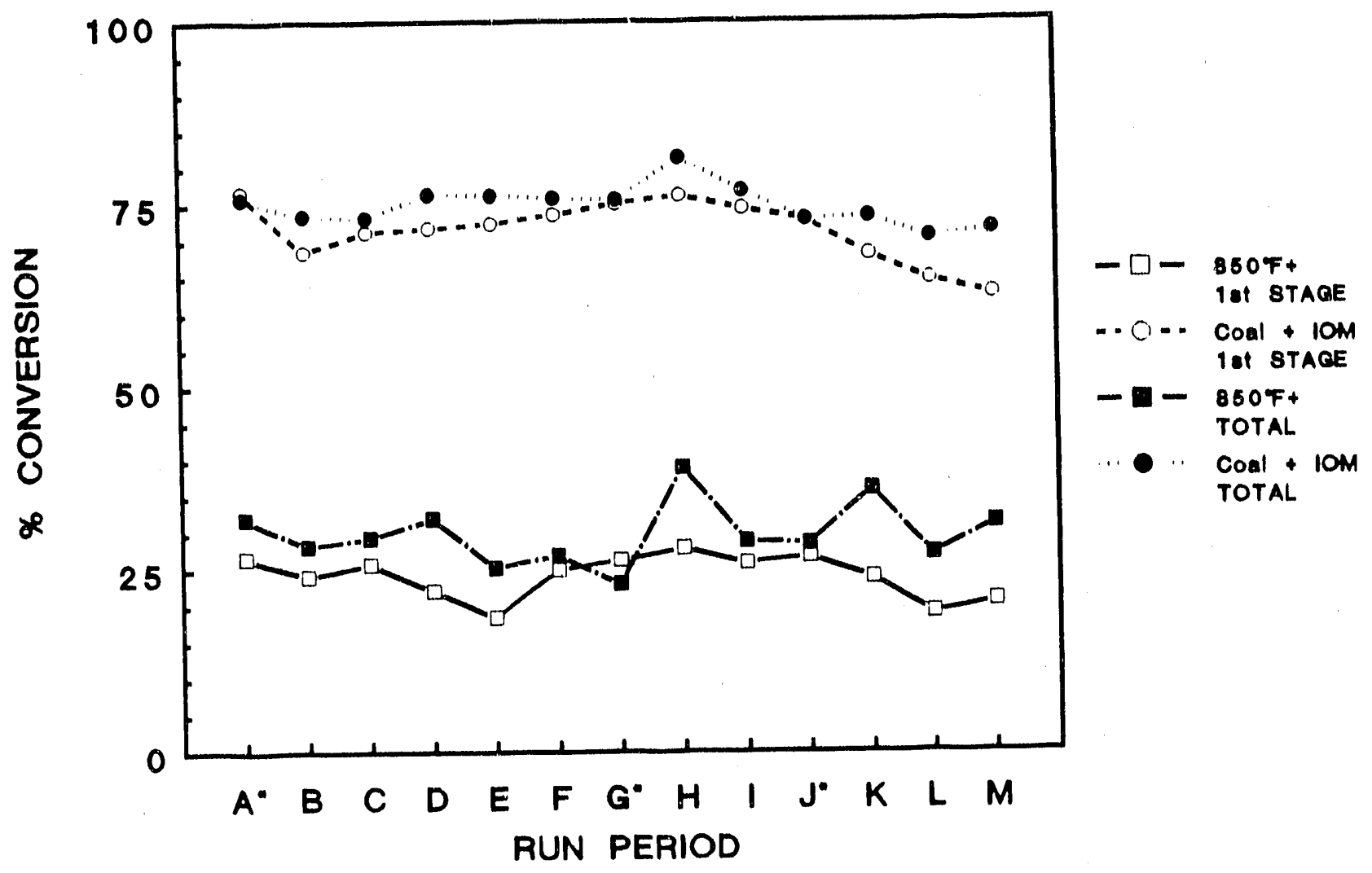

Figure 14. First-Stage and Total $850^{\circ} \mathrm{Ft}$

and Coal + IOM Conversions for Wilsonville Run 258. 


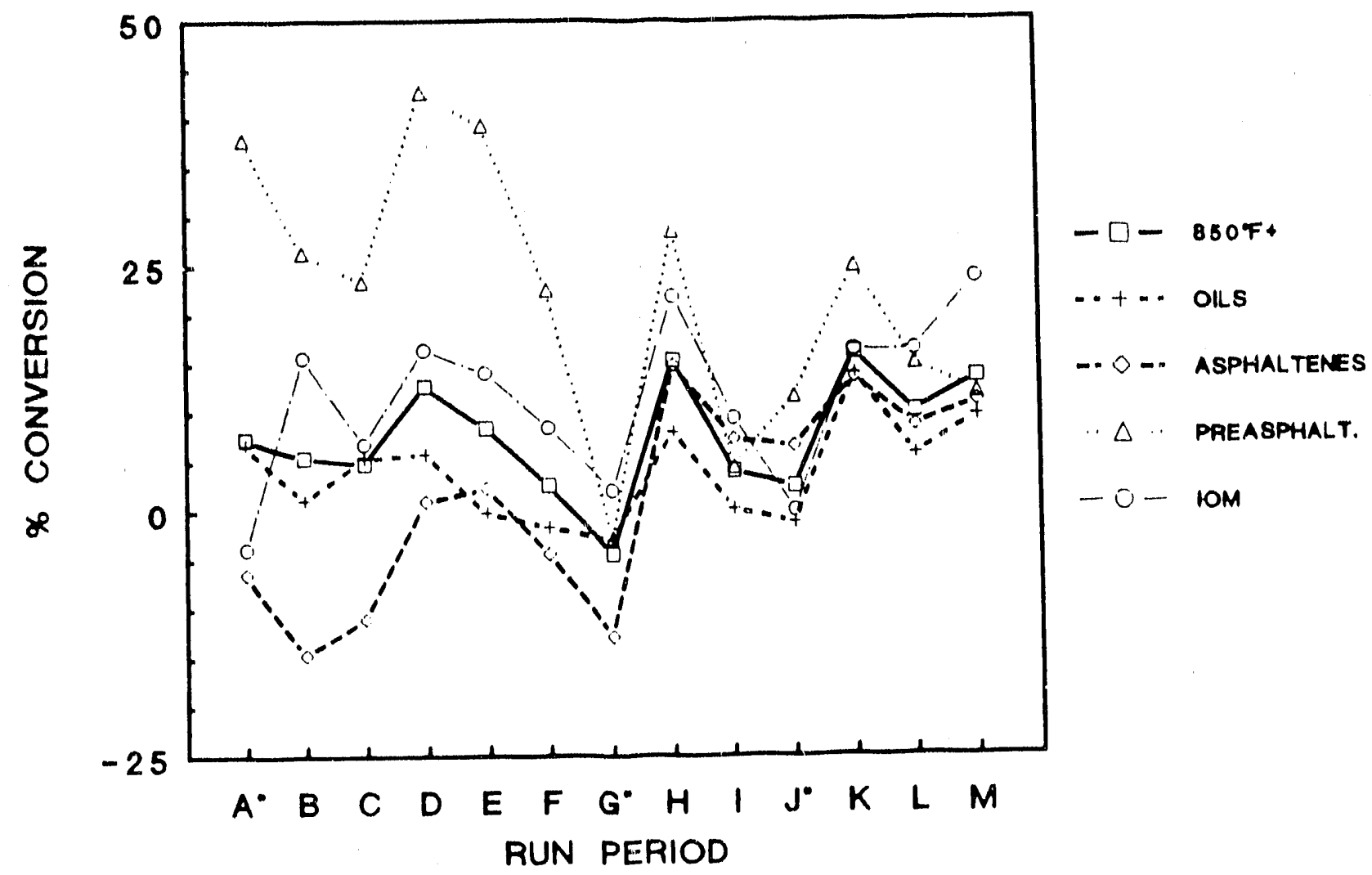

Figure 15. Second-Stage $850^{\circ} \mathrm{F}+$ Component Conversions for Wilsonville Run 258. 


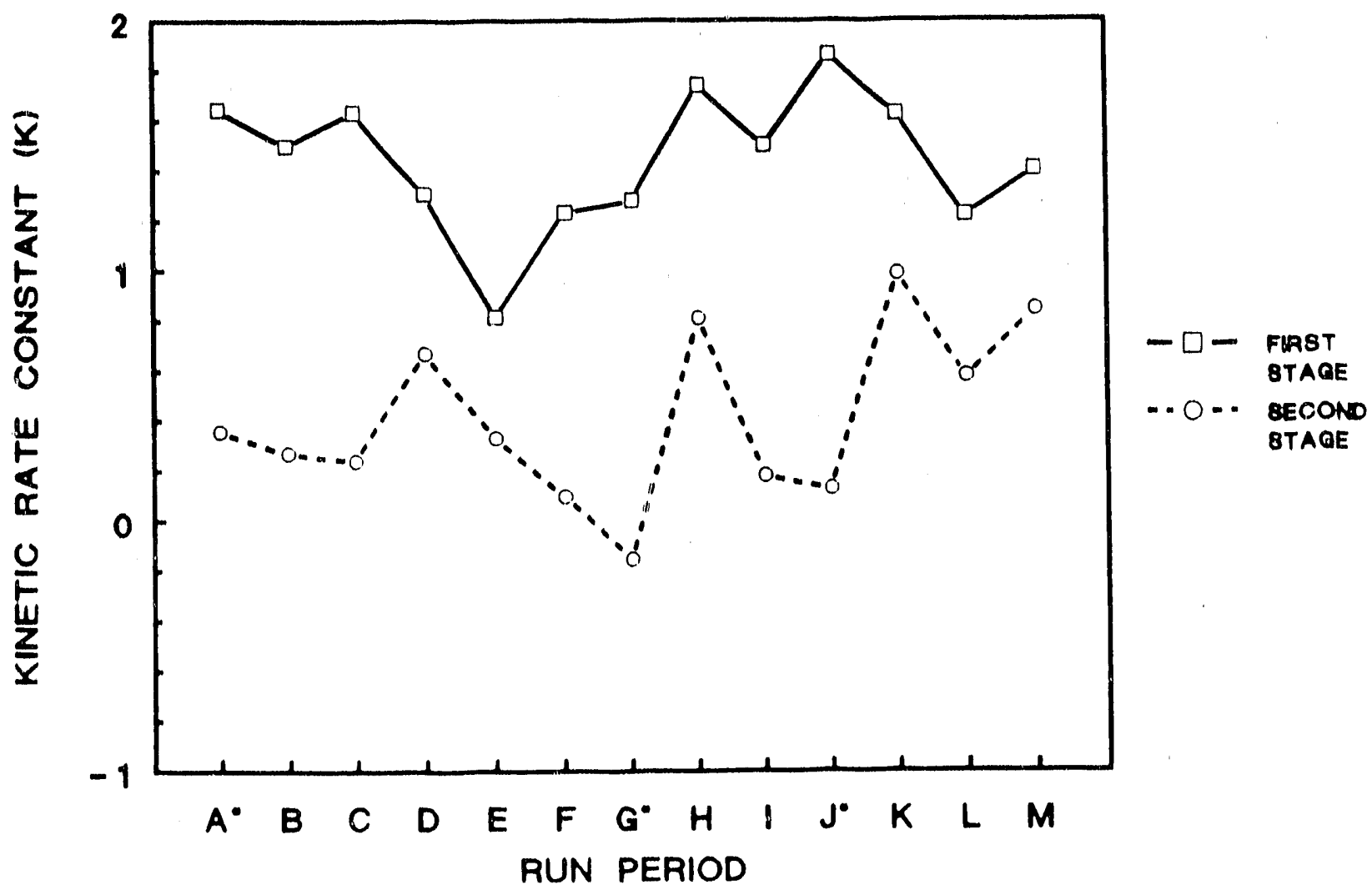

Figure 16. Kinetic Rate Constants for First- and Second-Stage $850^{\circ} \mathrm{Ft}$ Conversions for Wilsonville Run 258. 


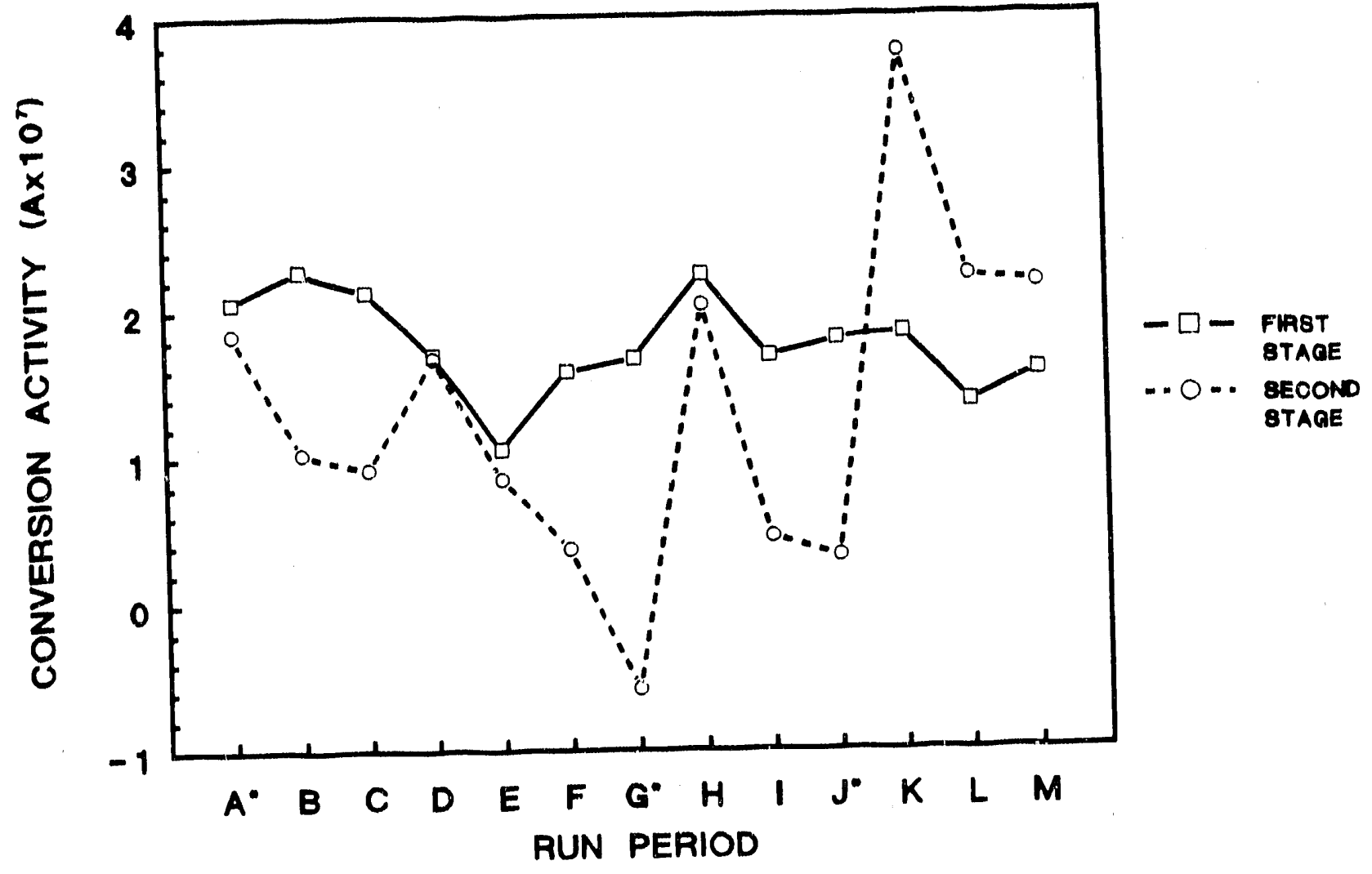

Figure 17. $850^{\circ} \mathrm{F}+$ Conversion Activities for First and Secord Stages in Wilsonville Run 258. 


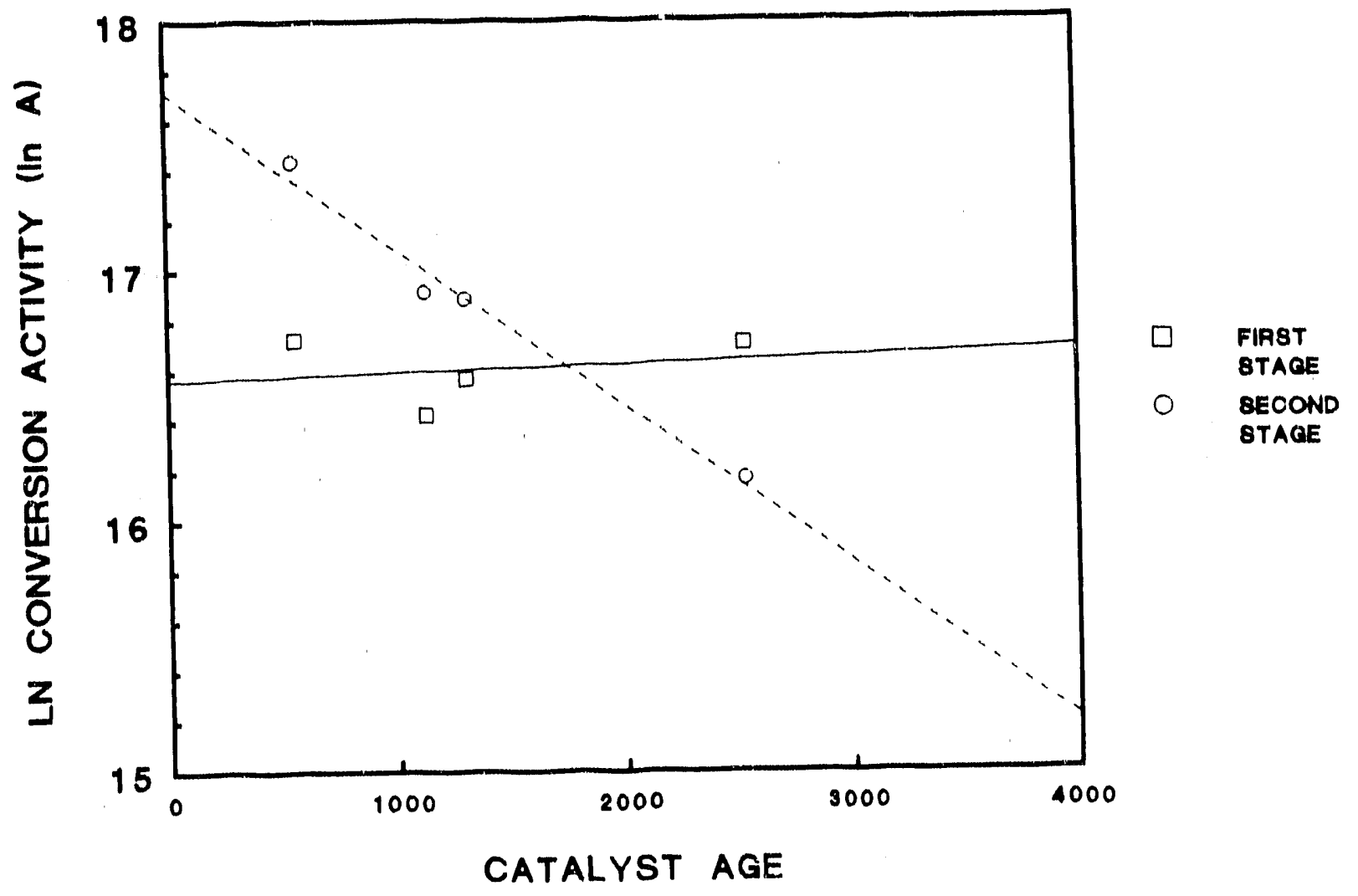

Figure 18. Catalyst Deactivation Plot for Wilsonville Run 258. 


\title{
APPENDIX 1
}

\section{APPLICATIONS OF COAL LIQUEFACTION SOLVENT QUALITY MEASUREMENTS}

\author{
F. P. Burke \\ Consolidation Coal Company \\ 4000 Brownsville Road \\ Library, PA 15129 \\ USA \\ For presentation at \\ Frontiers in Coal Science and Technology \\ Fukuoka, Japan \\ October 29-31, 1989
}

Most direct coal liquefaction processes use a recycle solvent as a vehicle to transport coal into the liquefaction reactor. This solvent also is a chemical reactant in the system, and potentially can enhance or inhibit the liquefaction reaction. Certainly the literature contains examples of model compounds which can be ranked as to "solvent quality" on the basis of their effectiveness in promoting coal dissolution. However, the issue of solvent quality becomes more complicated when put into context of a liquefaction process, the objective of which is not simply to dissolve coal, but to make marketable liquid products. In fact, in the current two-stage resid-recycle process configurations it has become less meaningful to attempt to isolate a "solvent" which is not at the same time a major feed to the liquefaction reaction. However, the study of recycle oil characteristics continues to provide insight into the nature of liquefaction reactions and the effect of process conditions on process performance. 
This presentation will discuss the characterization of recycle o1ls in direct coal liquefaction. Analytical and empirical methods of measuring solvent quality will be described. The presentation will then focus on the application of these methods to understanding the relationship between recycle ofl characteristics and coal liquefaction process performance. Spectfic topics will include the effect of solvent quality on thermal liquefaction reactions, the role of saturates in determining solvent quality, the evolution of recycle oil characteristics in two-stage liquefaction development, and the suftability of pyrolysis liquids as recycle ofl components. 


\title{
APPENDIX 2
}

THE EVOLUTION OF PROCESS OIL CHARACTERISTICS IN

TWO-STACE COAL LIQUEFACTION PROCESS DEVELOPMENT

\author{
F. P. Burke
}

\author{
CONSOLIDATION COAL COMPANY \\ Research \& Development \\ 4000 Brownsville Road \\ Library, PA 15129
}

\author{
Prepared for Presentation \\ AIST-ANRE-NEDO!DUE-PETC \\ Joint Technisa: Meeting on Coal Liquefac": n \\ Tokyo, Japan \\ $10 / 31-11 / 2 / 89$
}




\section{INTRODUCTION}

Over the last decade, work by Lummus-Crest Inc. (Lummus), Hydrocarbon Research Inc. (HRI), and by the participants in the Wilsonville Advanced Coal Liquefaction facility (Wiisonville) has led to Two-Stage Liquefaction process concepts which achieve high yields, good product qualities, and minimize hydrogen consumption. Demonstrated process improvernents have reduced anticipated product costs, and point the way to further cost reductions. Part of this development has been a systematic evaluation of process and recycle oil characteristics, conducted by Consol under DOE funding. Frequent (often daily) samples of key process streams are analyzed to relate recycle and product oil composition to process operating conditions and results. This paper provides a comparison of single- and two-.stage recycle and process oil characteristics.

\section{EXPERIMENTAL}

Over the last ten years, several thousand process and recycle oil samples were collected from the H-Coal, Lummus ITSL, HRI CTSL, and Wilsonville facilities. These samples were analyzed by a variety of techniques to relate process oil composition and process operations. The analytical methods have been documented in detail (1). Results presented in this paper include proton distributions by ${ }^{1} H-N M R$ spectroscopy (2), phenolic $-O H$ content by FTIR (3), and solubility fractionation (4). The IH-NMR data are represented by a paraffinic term (PAR $=\&$ alkyl $B$ protons), a hydroaromatic term (HAR = cyclic/total aliphatic protons), and an aromatic term $(A R=$ aromatic/aliphatic protons $)$. These terms were used to calculate a relative solvent quality indicator ba:ed on correlation with microautoclave liquefaction experiments at the Modified-Equilibrium conditions (2). Because of the extensive data base developed in this work, it is possible to assure that samples and analytical results are truly representative of the particular process and operating mode. The process oils described in this report were chosen because they typify the development of the two-stage process concept from a single-stage catalytic process (H-Coal) to a two-stage thermal/catalytic process (Lummus and Wilsonville Run 242), and recently to a two-stage catalytic/catalytic process (Wilsonville Run 257, HRI Run 1-27). Samples were chosen only from runs using Illinois 6 coal from the Burning Star 2 Mine. The impact of feed coal on process oil characteristics was discussed previously (b) , and does not affect the conclusions developed below.

\section{RESULTS AND DISCUSSION}

\section{H-Coal}

The H-Coal process, deve'oped by HRI, uses a single ebullated bed catalytic reactor to convert coal to liquids. The prototypical H-Coal run with lllinois 6 coal (PDU Run 5) was made on the 3TPD H-Coal PDU in 1977 (6). This 30-day rur employed continuous catalyst addition and withdrawal to achieve steady-state operations by about day 20. Run PDU5 used HDS $1442 \mathrm{~A}(\mathrm{Co} / \mathrm{Mo} / \mathrm{Al})$ catalyst at a reactor temperature of $850^{\circ} \mathrm{F}$. The slurry recycle oil in the $\mathrm{H}$-Coal process is a cumposite of distillate $\left(975^{\circ} \mathrm{F}^{-}\right.$) and residual product oils, including some insoluble organic r.aterial and ash. Data are presented in Table 1 for the distillate portions 
of the slurry oil and for the whole oll. including the THF soluble resid. Because of the high operating temperature, the product oils are relatively high in aromatic protons, but low in paraffinic protons. Thermal cracking predominates over hydrogenation. The phenolic $-\mathrm{OH}$ content of the product distillate is relatively high. The calculated solvent quality value is moderate. Values above 80 represent a good solvent; values below 70 are poor.

Lummus ITSL

Run 3LCF9 was made on the Lummus bench unit in 1982 (7). In the Lummus ITSL process, a short contact time (SCT) reactor converts coal in a recycle donor solvent to prepare a feed for the second-stage LC-Fining (LCF) unit. Nominal residence time in the SCT unit is about $2 \mathrm{~min}$. For the run periods considered here, the SCT product was fed directly to the LC-Finer; there was no interstage deashing. Representative conditions include reactor temperature of $840^{\circ} \mathrm{F}$ (SCT unit), $750-780^{\circ} \mathrm{F}$ (LC-Finer), and Shell $324 \mathrm{M}$ ( $\mathrm{Ni} / \mathrm{Mo} / \mathrm{Al})$ catalyst. The purpose of separating the two stages is to convert coal rapidly to an upgradable resid at high temperature, but short residence time to limit retrograde reactions. The LC-Finer converts the resid at lower temperature more suitable to hydrogenation, simultaneously providing the high quality recycle solvent needed to promote conversion and limit retrograde reactions in the SCT unit. The results in Table 1 indicate the success with which these objectives were met. The high levels of preasphaltenes, aromatic protons and phenolic $-O H$ in the interstage sample reflect the minor degree of upgrading which occurs in the SCT unit. However, the LC-Finer substantially hydrogenates the process oil, reducing preasphaitenes and phenolic - $\mathrm{OH}$. It also prepares an excellent recycle donor solvent, as indicated by the high solvent quality value $(\sim 908)$. By operating the catalytic reactor at lower temperature, the Lummus ITSL process avoids the aromatization of the process oil that characterizes the higher temperature $\mathrm{H}$-Coal process. However, the resid phenol content $(0.79 \mathrm{meq} / \mathrm{g}$ on whole oil) and preasphaltene content (19 wt $\&$ of THF soluble resid) remained relatively high.

Wilsonville ITSL - Run 242

Wilsonville Run 242, begun in late 1982, was a partial scale-up of the Lummus ITSL process (8). The first stage was operated in the SCT mode. However, the first stage severity was greater because of a higher temperature $\left(-860^{\circ} \mathrm{F}\right)$ and a longer residence time then in Lummus ITSL. The first-stage product was vacuum distilled and the vacuum bottoms were deashed in the Kerr-McCee critical solvent deasher (CSD). The deashed product was fed to an ebullated bed hydrotreater (HTR), operated at $750^{\circ} \mathrm{F}$ using Shell $324 \mathrm{M}(\mathrm{Ni} / \mathrm{Mo} / \mathrm{Al})$ catalyst. The CSD unit between the SCT and HTR selectively removes preasphaltenes as shown in the comparison below of solubility fractionation data averaged over the run.

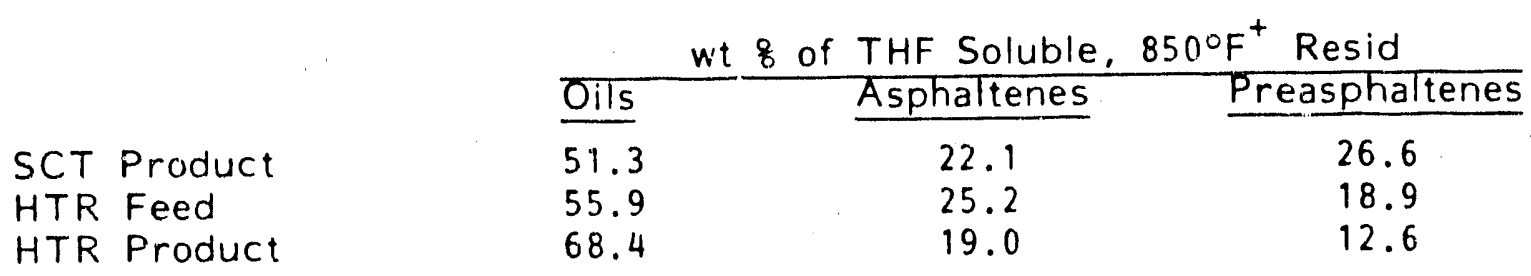


The distillate portion of the SCT product bypasses the CSD unit, and is equivalent to the HTR feed distillate (Table 1). Despite the points of similarity. Wilsonville Run 242 produced very different process oils than Lummus ITSL. The saturate contents were higher: aromatics were lower. The residual product oils were much lower in asphaltenes and preasphaltenes. The differences between SCT and HTR product oils remained, but were not as pronounced as for the Lummus ITSL counterparts. Apparently the greater first-stage severity and interstage deashing at Wilsonville produced higher quality process oils. However, the solvent quality of the second-stage product dropped from around 90 for Lummus ITSL to 80 for Wilsonville Run 242.

\section{HRI Run 1-27: Catalytic/Catalytic Two-Stage Liquefaction}

Run 1-27 was a demonstration CTSL run made in May-June 1987 (9). The HRI CTSL process uses two ebullated bed catalytic hydrotreaters in series. The first is operated at a relatively low temperature (in this case, $758^{\circ} \mathrm{F}$ ) to convert coal to a resid and to hydrogenate the resid and recycle oil. The higher temperature second reactor $1813^{\circ} \mathrm{F}$ in the run period considered here) converts the resid to a distillate product. The benefit of the catalytic first stage is most apparent in the relatively low preasphaltenes, phenolic $\cdots \mathrm{OH}$, and aromaticity of the interstage product. The higher temperature second stage is effective in further reducing phenols and preasphaltenes, but increases the aromaticity of both the distillate and residual oils. Solvent qualities are in the mid-80s, comparable to those from the Wilsonville ITSL run.

\section{Wilsonville Run 257D}

Subsequent to Run 242, the Wilsonville facility continued to evaluate various two-stage liquefaction processing modes, eventually leading to a catalytic/catalytic two-stage operation with direct coupling of the two reactors (no interstage deashing). However, in contrast to HRI's CTSL process. Wilsonville operated the first stage at higher temperature than the second ( $\mathrm{Hi} / \mathrm{Lo} v \mathrm{~s} \mathrm{Lo} / \mathrm{Hi}$ temperature staging). In Run period 257D, the Wilsonville unit was operated in this $\mathrm{Hi} / \mathrm{Lo}$ mode at reactor temperatures of $790^{\circ} \mathrm{F}$ and $760^{\circ} \mathrm{F}(10)$. Catalyst (Amocat $1 \mathrm{C}, \mathrm{Ni} / \mathrm{Mo} / \mathrm{Al}$ ) was continuously replaced in each reactor. The oil properties from Run 257D (Table 2) are very similar to those from CTSL Run 1-27. One difference is that the $1-27$ oils show the effect of the Lo/Hi temperature staging in the higher phenolic-OH, higher preasphaltenes, and lower aromaticity of the interstage sample, compared to the product oils. With Hillo staging in Run 257, the differences are less pronounced, particularly in comparing the proton terms, and for the whole oil. Based on these and other data from Wilsonville, the second-stage reactor in $\mathrm{Hi} / \mathrm{Lo}$ CTSL operation converts resid to distillate, but has almost no effect on the properties of the oils as described here.

Wilsonville Run $257 \mathrm{C}$ - Lo/Hi Catalytic/Catalytic Operation

Run period $257 \mathrm{C}$ was the first made at Wilsonville using Lo/Hi temperature staging. Conditions were very similar to those in $257 \mathrm{D}$, except that the reactor temperatures were reversed $1760^{\circ} \mathrm{F}$ first stage, $790^{\circ} \mathrm{F}$ second 
stage). The most apparent responses, compared to $257 \mathrm{D}$, are an increase in interstage preasphaltenes, and a more pronounced decrease in phenolic $-\mathrm{OH}$ and preasphaltenes across the (now) higher temperature second stage reactor. Solvent qualities during both run periods $257 \mathrm{D}$ and 257C are good, and are relatively insensitive to sample location or run configuration.

\section{CONCLUSIONS}

The evolution of coal liquefaction technology from a single-stage catalytic process to a two-stage thermal/catalytic process, to the current two-stage catalytic/catalytic processes has been accompanied by corresponding changes in the characteristics of the process and recycle oils. The current process configurations minimize the concentrations of undesirable components, such as phenolics, aromatics, and preasphaltenes, throughout the liquefaction system. At the same time, recycle solvent qualities are uniformly good, and are generally improved by the presence of hydrogenated residual oils. The $\mathrm{Hi} /$ Lo temperature staging sequence may be particularly beneficial in maintaining a nearly constant process oil composition throughout the system, because it minimizes preasphaltene content in the interstage oil. However, the differences between Lo/Hi and $\mathrm{Hi} /$ Lo temperature stages appear to be minor.

\section{ACKNOWLEDGMENT}

This work was funded by the U.S. Department of Energy under Contracts $79 E T-14503,80 \mathrm{PC}-30027$ and 84PC-70018.

\section{REFERENCES}

1. Burke, F. P., Winschel, R. A. et al. - Reports under DOE contracts 14503,30027 and 70018 .

2. Winschel, R. A., Robbins, C. A., Burke, F. P., Fuel 65(9), 526, 1986.

3. Robbins. G. A., Winschel, R. A., Burke, F. P., ACS Fuel Chem. Div. Prepr., 30(4), 155, 1985.

4. Burke F. P., Winschel, R. A., Wooton, D. C., Fuel 58, 539 (1979).

5. Derbyshire, F. J., Stansberry, P. C., Burke, F.'P.. Winschel, R. A., Proceedings Intl. Conf. Coal Sci., p. 25, Maastricht (1987).

6. Burke, F. P., Winschel, R. A., ACS Fuel Chem. Div. Prepr., 26(3), $90,1981$.

7. Winschel, R. A., Burke, F. P., Technical Report: 10/1/82-3/21/83, DOE/PC 30027-46, February 1984

8. Burke, F. P., Winschel, R. A., Robbins, G. A., Third Annual Report: $10 / 1 / 82-9 / 30 / 83$, DOE/PC 30027-56, October 1984.

9. Winschel, R. A., Robbins, G. A., Burke, F. P., Technical Progress Report; 4/1/87-6/30/87, DOE/PC 70018-46, February 1988.

10. Winschel, R. A., Robbins, G. A., Burke, F. P., Technical Progress Report, 7/1/88-9/30/88, DOE/PC 70018-68, July 1989. 


\section{SUMMARY}

- EVOLUTION OF TWO-STAGE CATALYTIC PROCESS HAS RESULTED IN GENERAL IMPROVEMENT IN PROCESS OIL CHARACTERISTICS, CONCURRENT WITH YIELD IMPROVEMENTS.

- REDUCTION IN MAXIMUM REACTION TEMPERATURE HAS RESULTED IN LESS AROMATIC PROCESS OILS.

- INTERSTAGE REJECTION OF PREASPHALTENES HAD A PROFOUND EFFECT IN WILSONVILLE THERMAL/CATALYTIC ITSL.

- CATALYTIC FIRST STAGE ACCOMPLISHES SIMILAR PREASPHALTENES REDUCTION IN CATALYTIC/CATALYTIC PROCESSES.

- all catalytic/CATALYtic data aRe comparable.

- HI/LO TEMPERATURE STAGING MAY OFFER SOME ADVANTAGE IN REDUCING INTERSTAGE PREASPHALTENES.

- INTERSTAGE AND RECYCLE OILS WITH HI/LO TEMPERATURE STAGING ARE VERY SIMILAR IN COMPOSITION. 


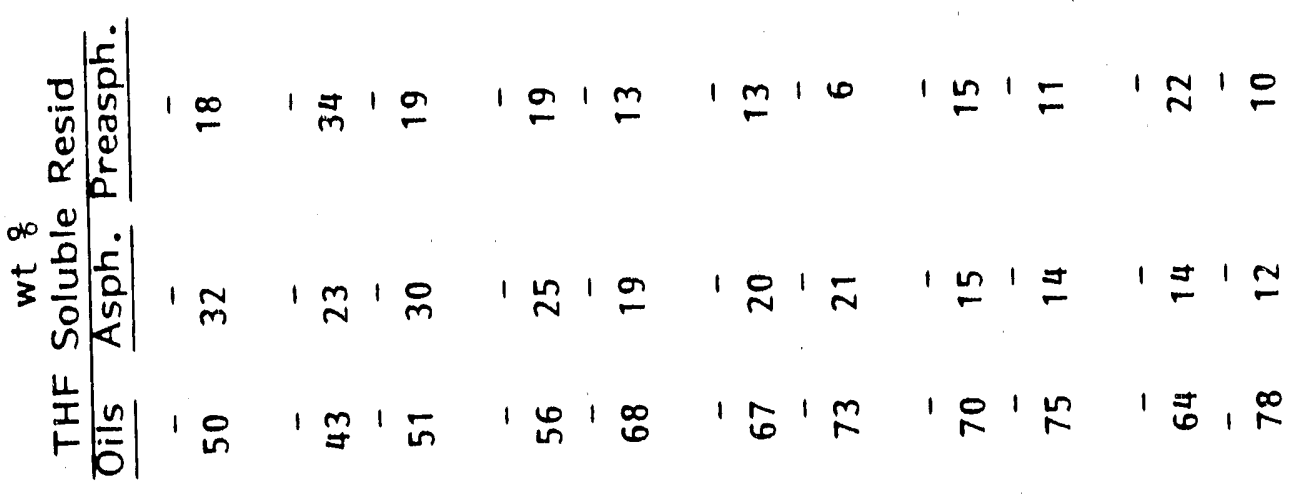

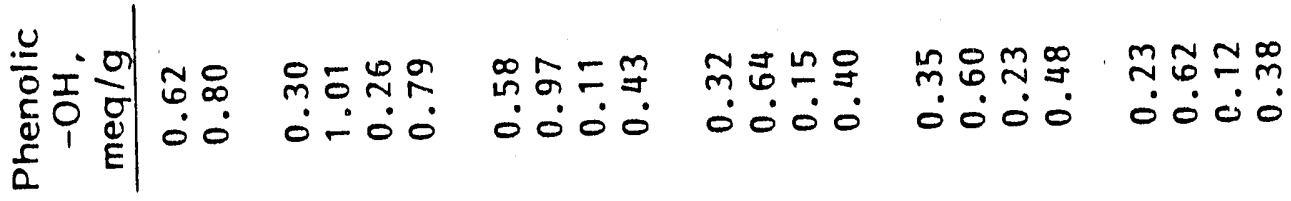

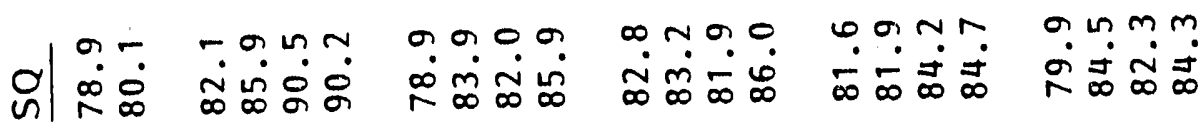

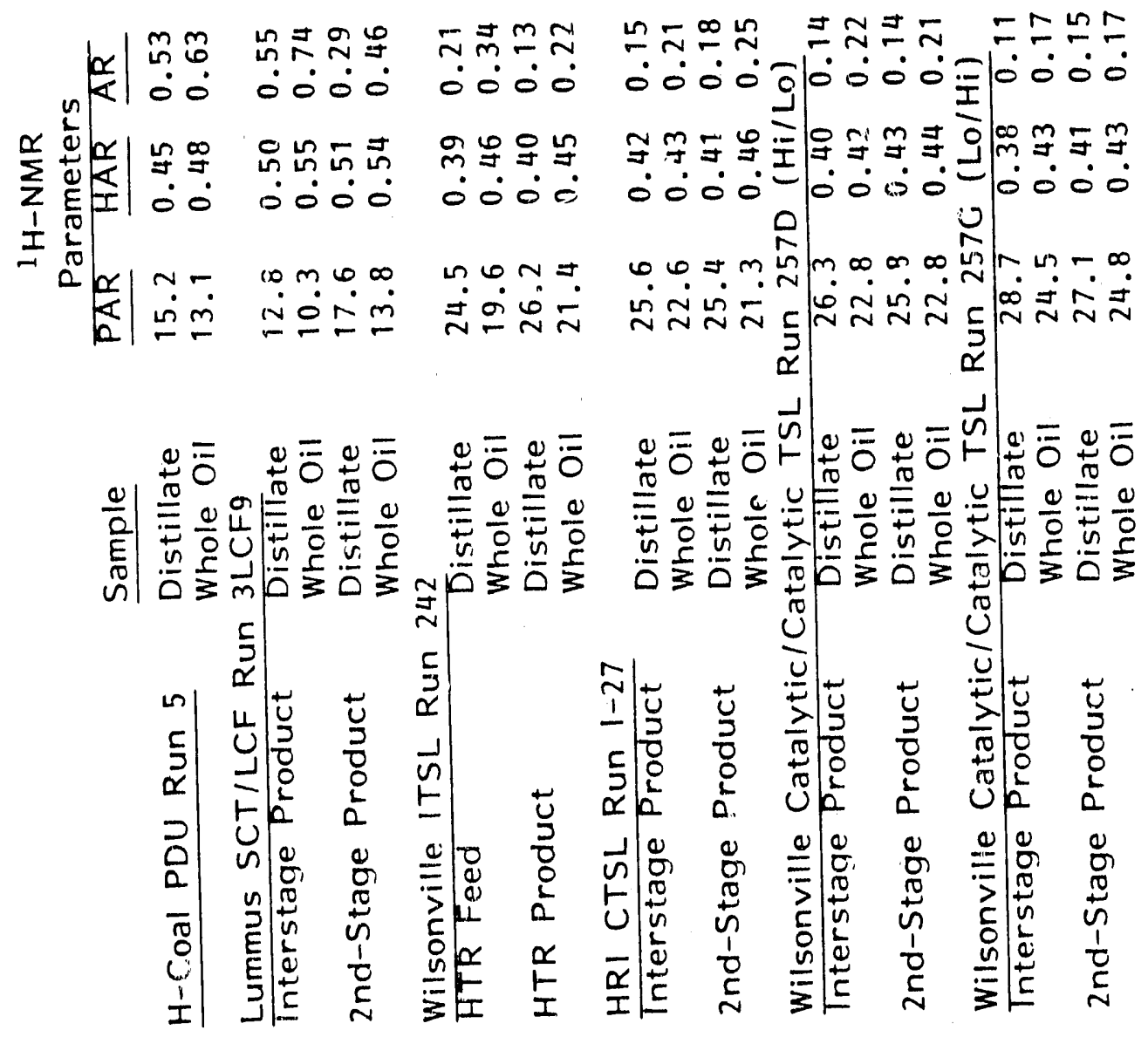




\section{INTRODUCTION}

- COMPARISON OF PROCESS OIL CHARACTERISTICS

- BENCH, PDU, AND PILOT PLANT OPERATIONS

- H-COAL PDU RUN 5 (1977)

- LUMMUS ITSL RUN 3LCF9 (1982)

- WILSONVILLE ITSL RUN 242 (1982-1983)

- HRI CTSL RUN I-27 (1987)

- WILSONVILLE ITSL RUNS 257D AND G (1989)

- SECOND STAGE FEEDS (EXCEPT H-COAL) REPRESENT FIRST STAGE PRODUCTS

- RECYCLE OILS REPRESENT SECOND STAGE PRODUCTS 


\section{COMPARISON PARAMETERS}

- ANALYSES OF DISTILLATES AND WHOLE OILS

- ${ }^{3} H-N M R$

- PARAFFINIC TERM (PAR) $=\div$ ALKYL BETA PROTONS

- HYDROAROMATIC TERM (HAR) = CYCLIC TO TOTAL

$$
\text { ALIPHATIC RATIO }
$$

- AROMATIC TERM (AR) = AROMATIC TO ALIPHATIC RATIO

- SOLVENT QUALITY INDICATOR (SO) CALCULATED FROM ${ }^{1}$ H-NMR

- PHENOLIC -OH BY FTIR

- PREASPHALTENES (WT \% THF SOLUBLE RESID) 


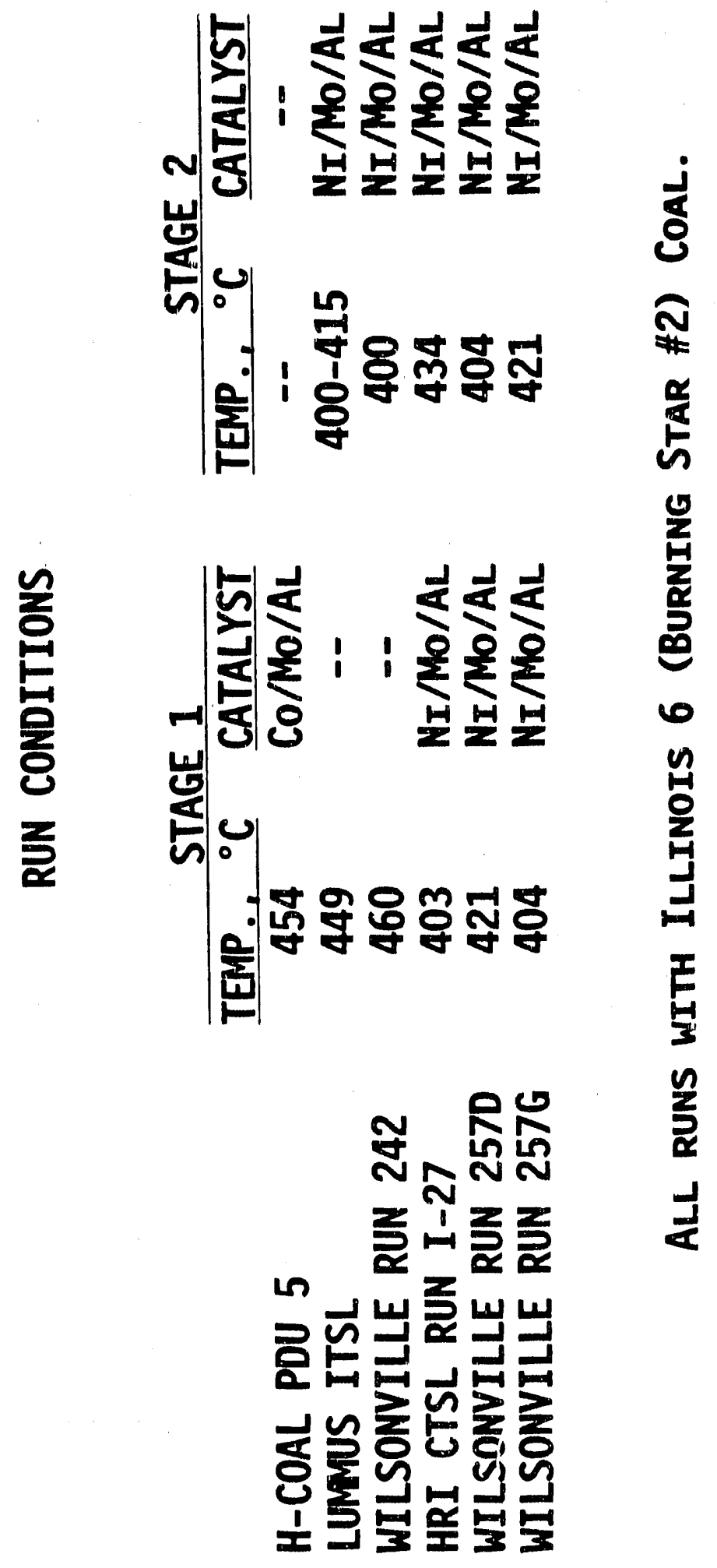




\section{H-COAL PDU \\ RUN 5}

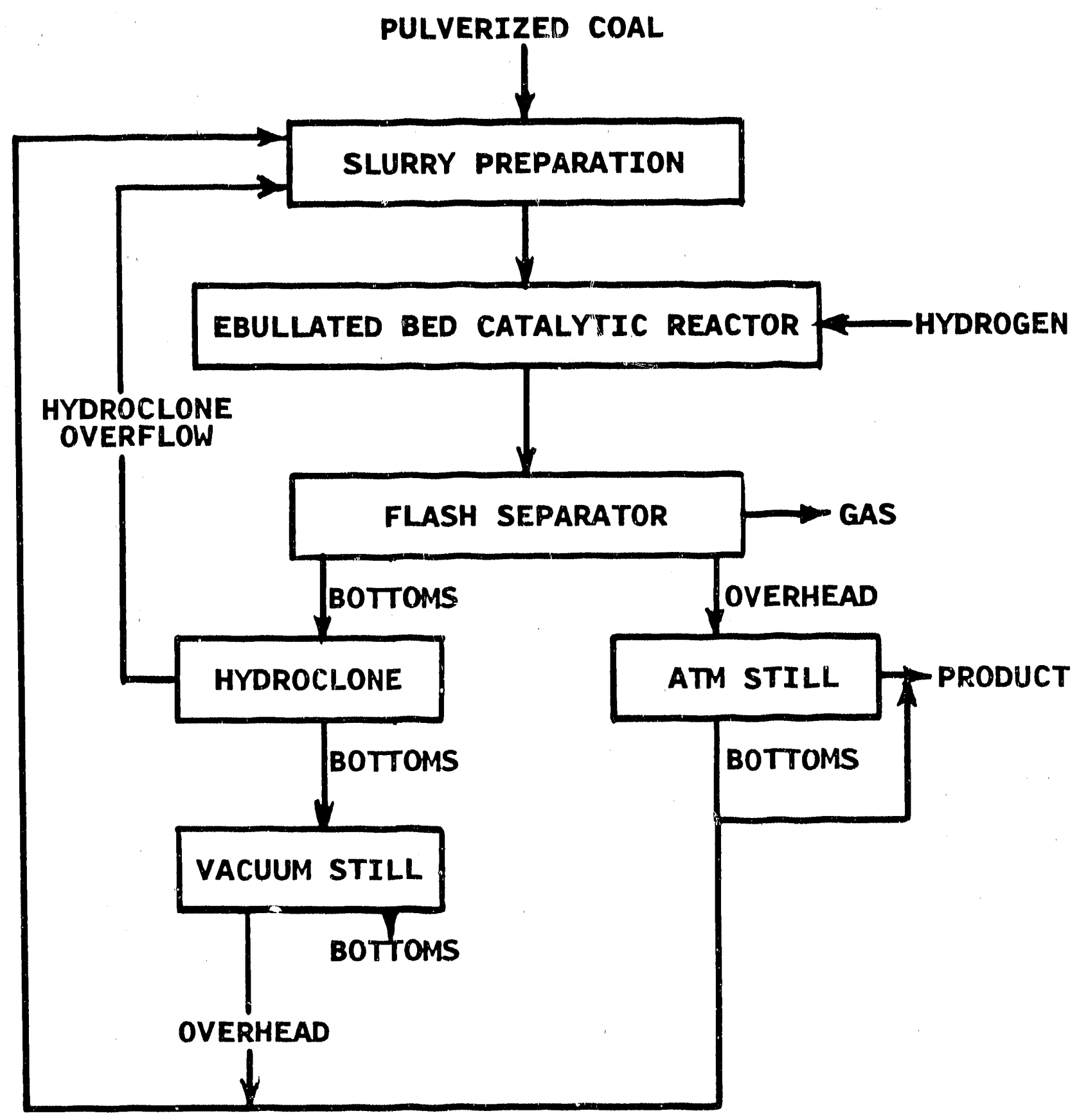




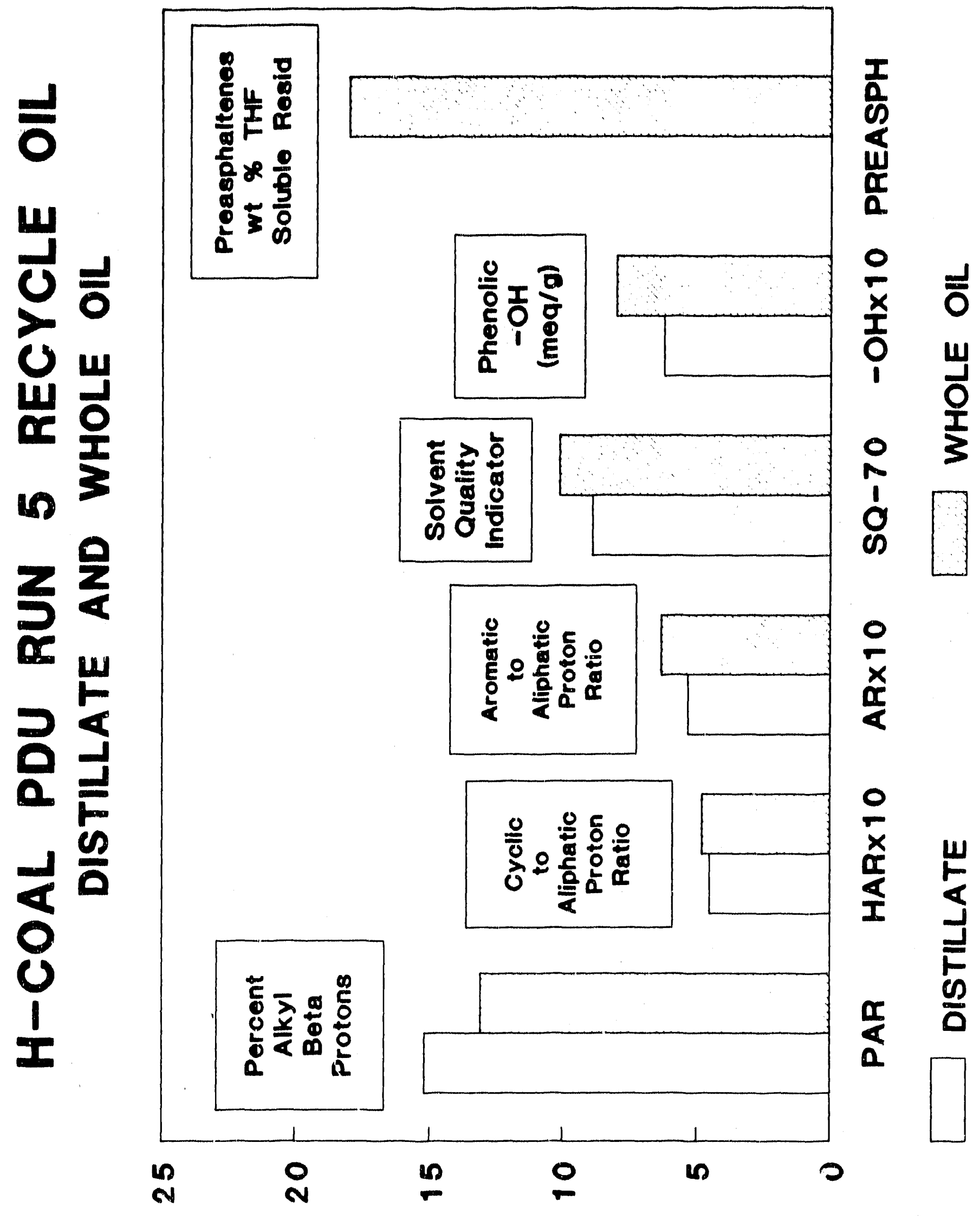




\section{LUMMUS INTEGRATED TWO-STAGE LIQUEFACTION \\ RUN 3LCF9}

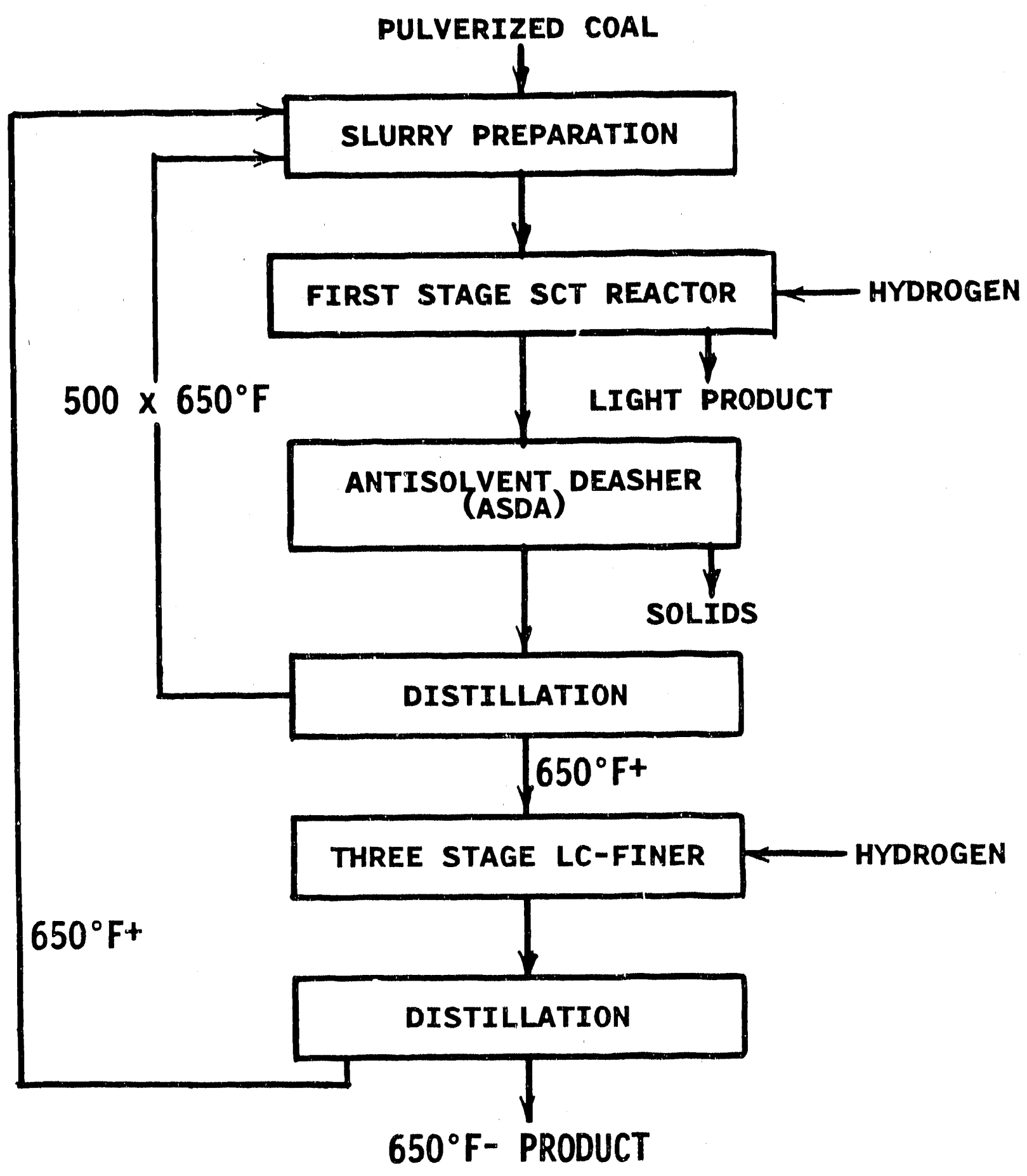




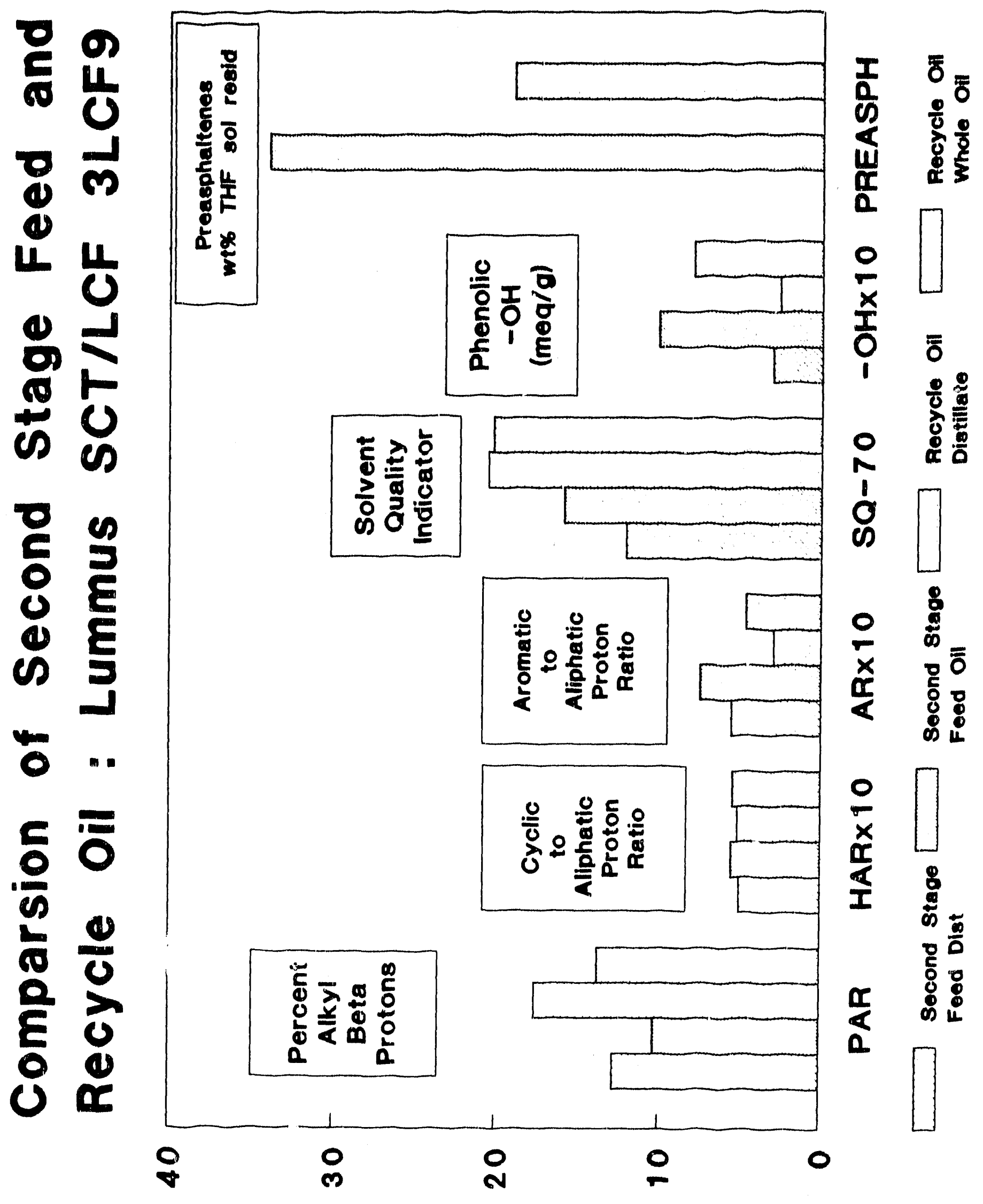




\section{WILSONVILLE SCT/ITSL}

RUN 242

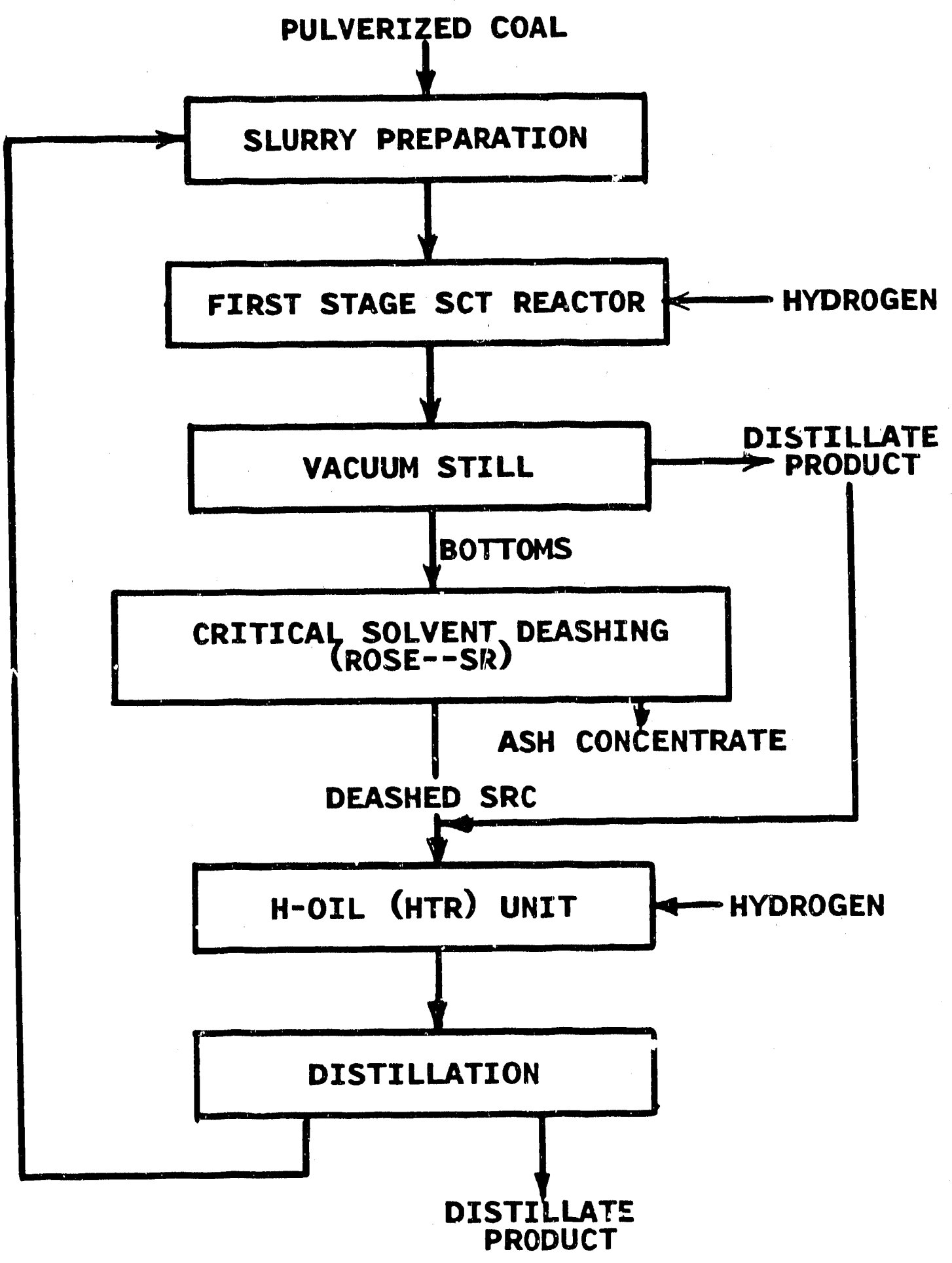




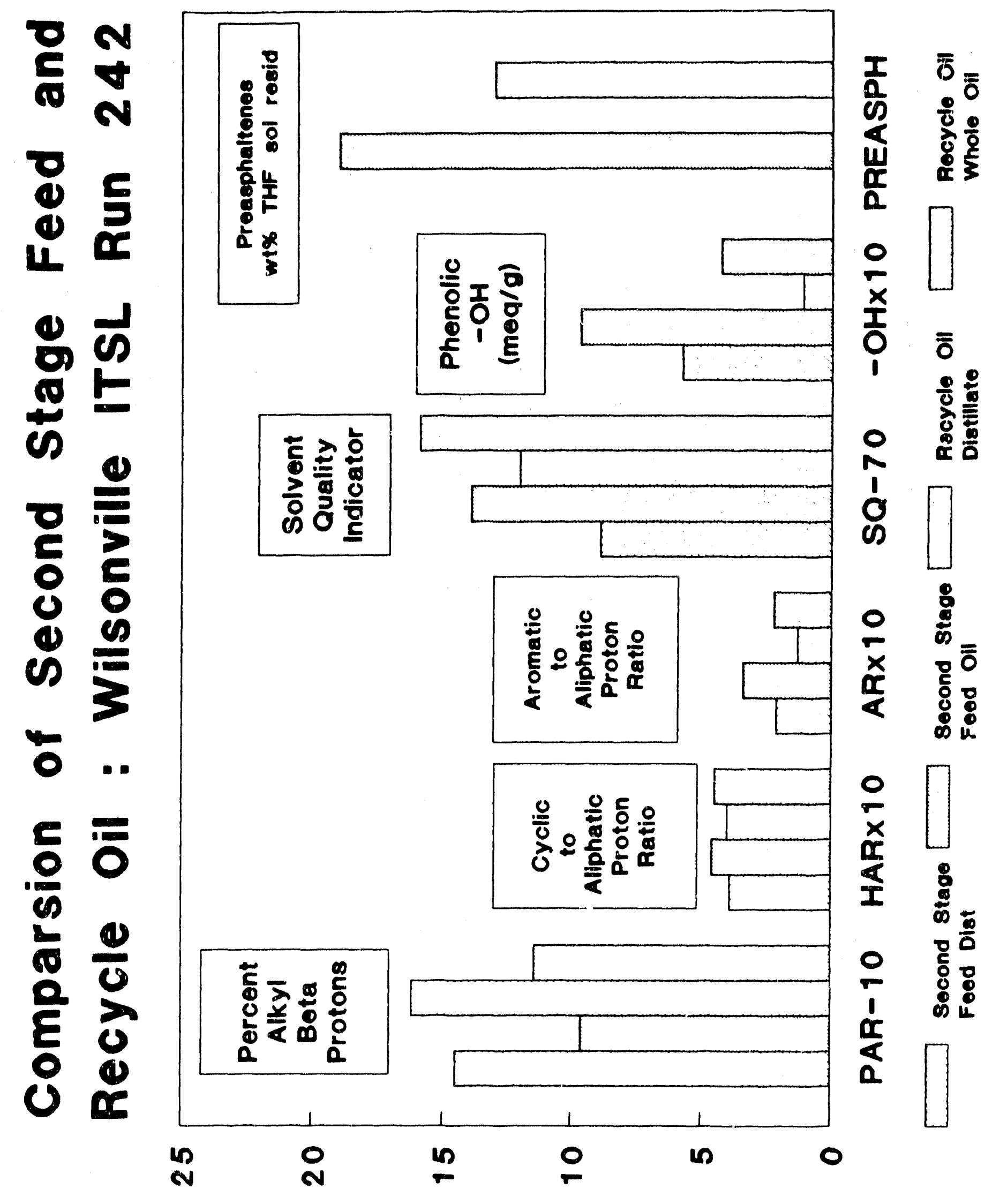




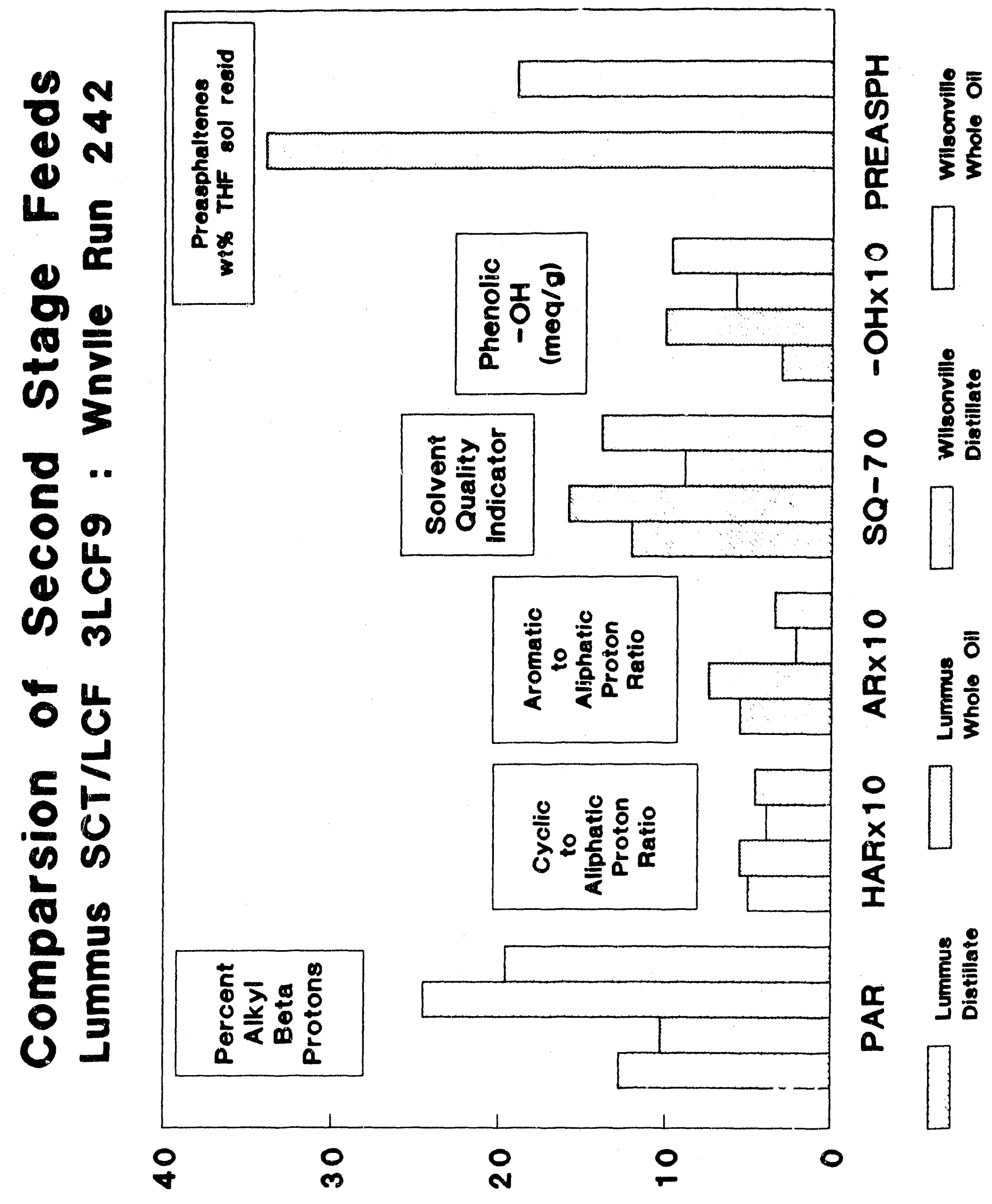




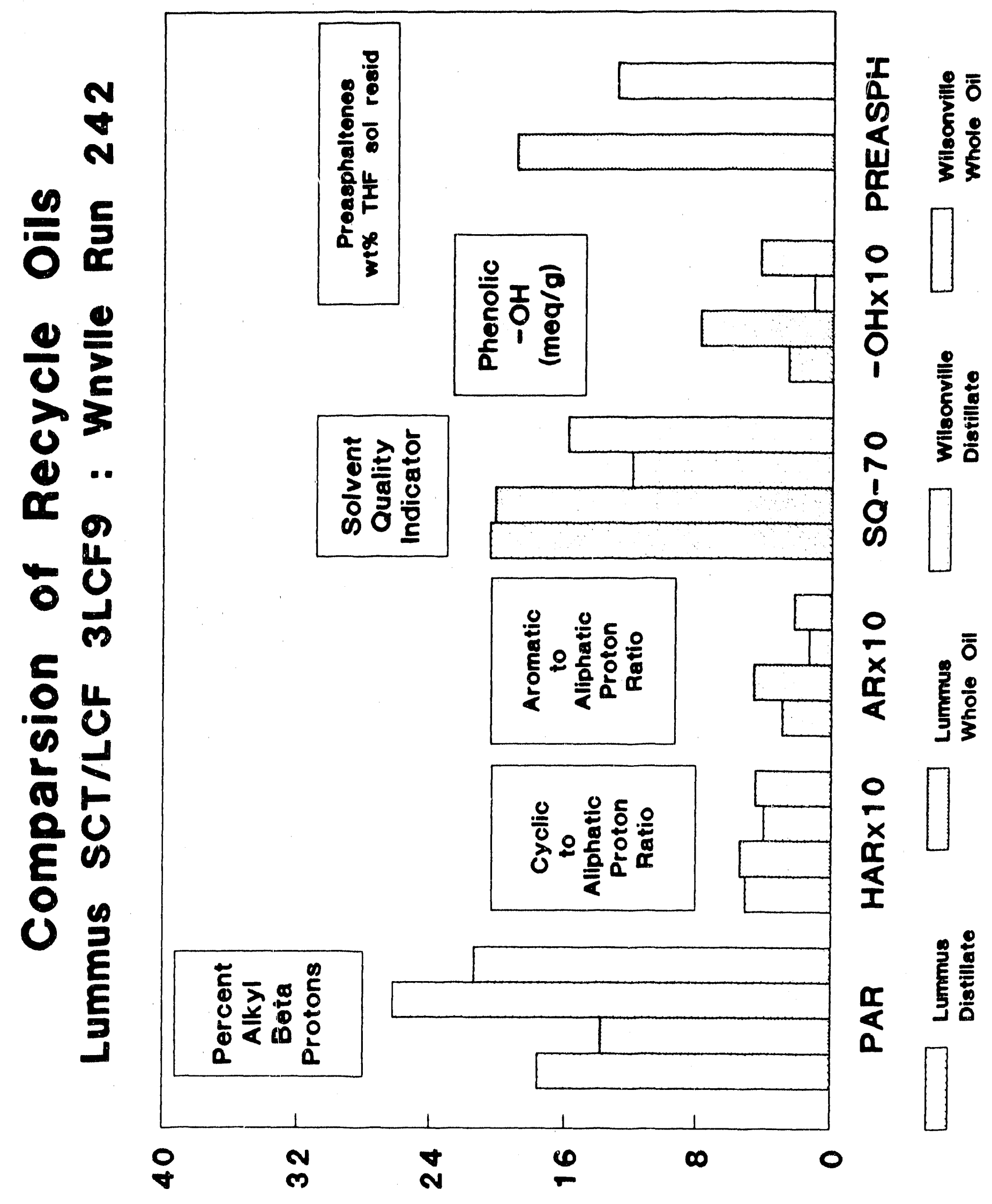




\section{HRI CLOSE COUPLED TWO-STAGE LIQUEFACTION \\ BENCH UNIT RUN I-27}

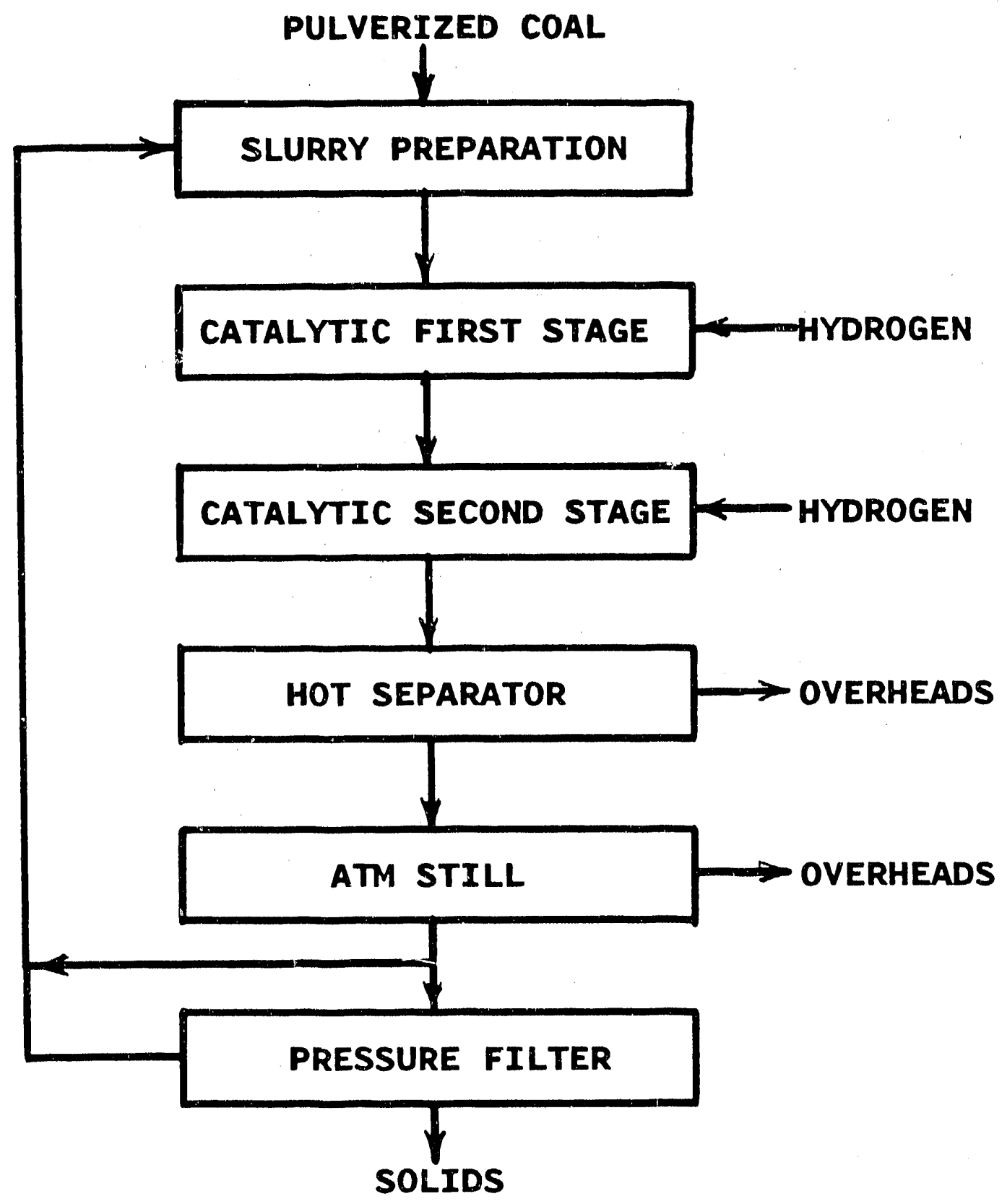




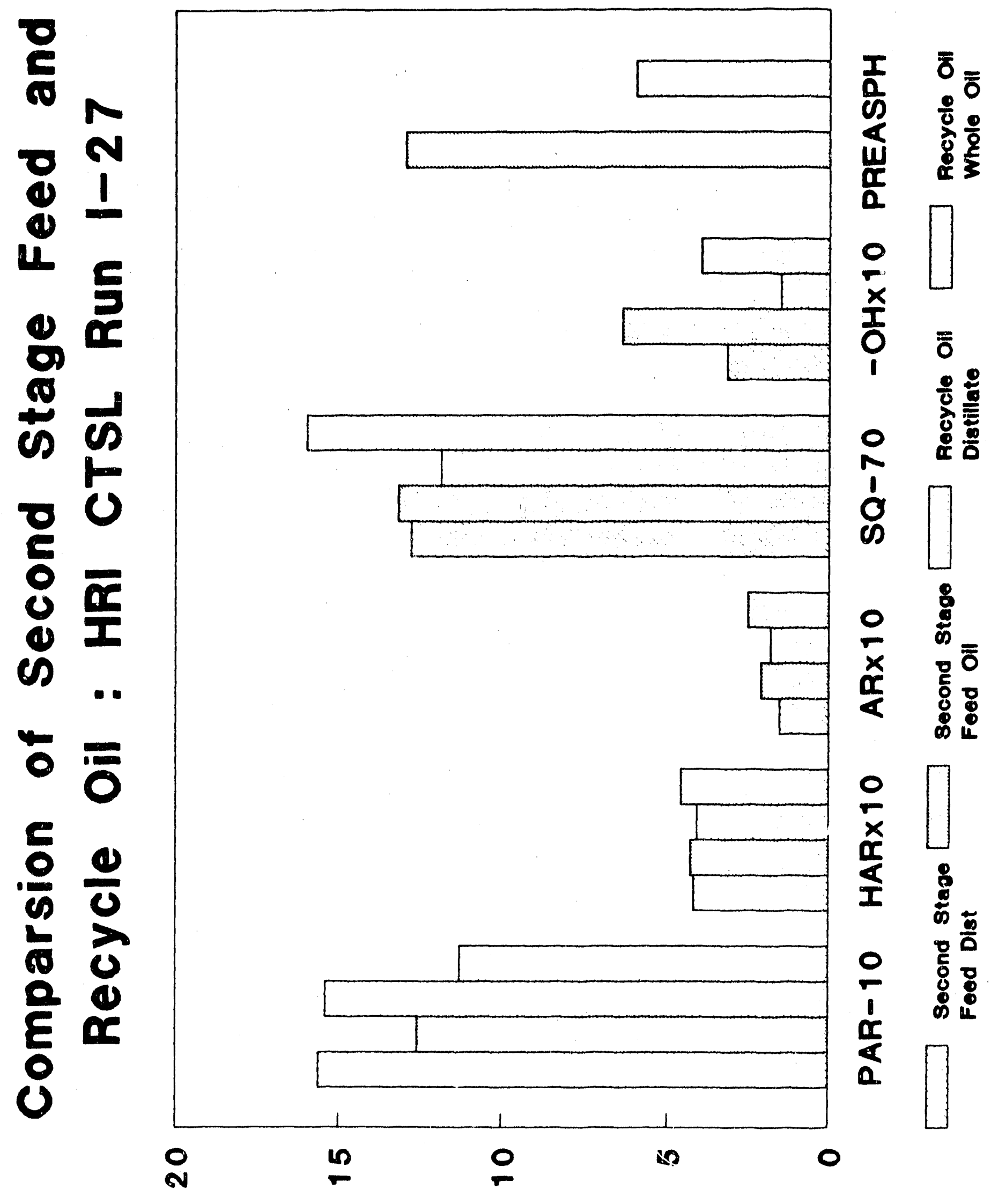


WILSONVILLE CC/ITSL

RUN 257D

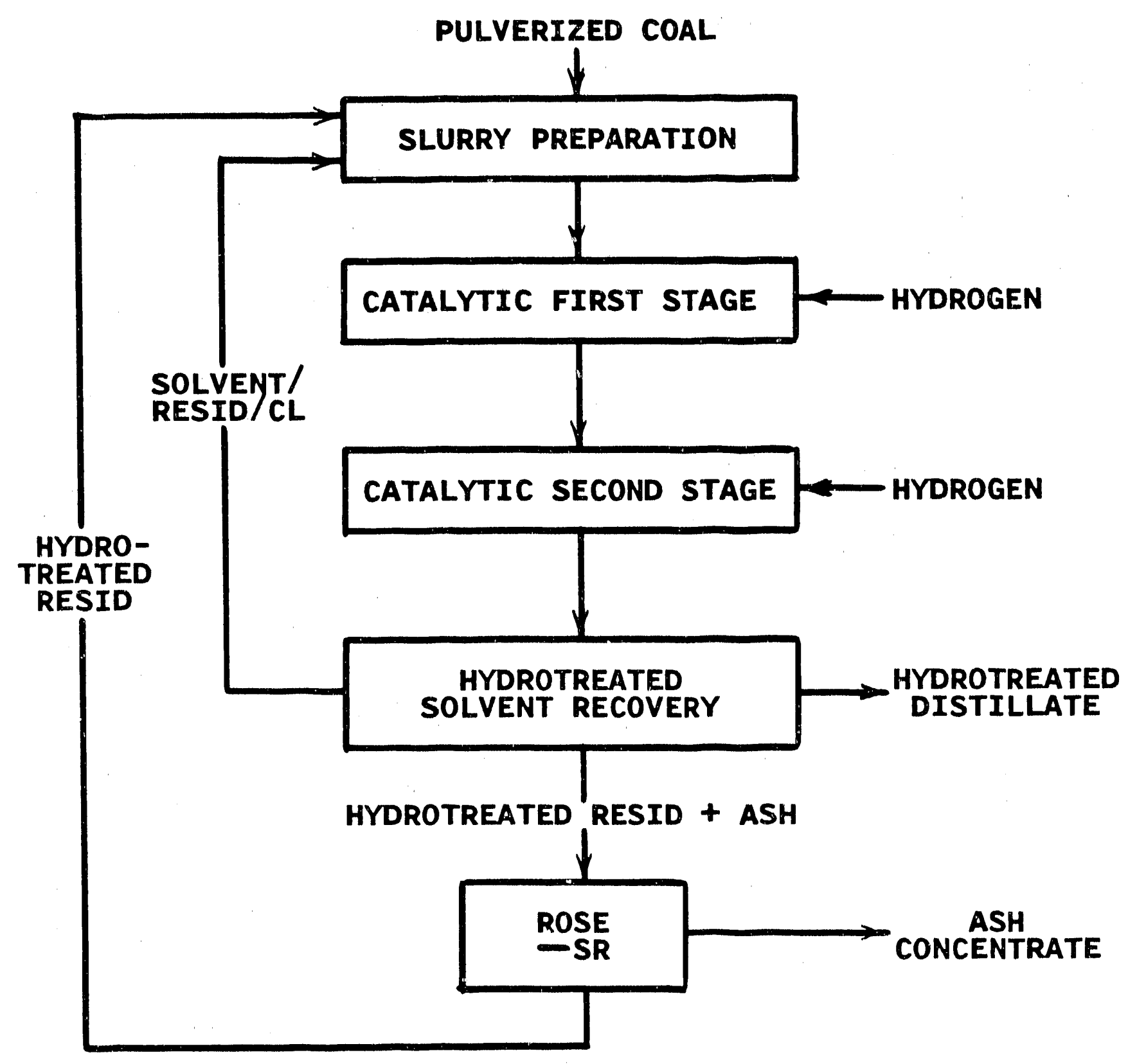




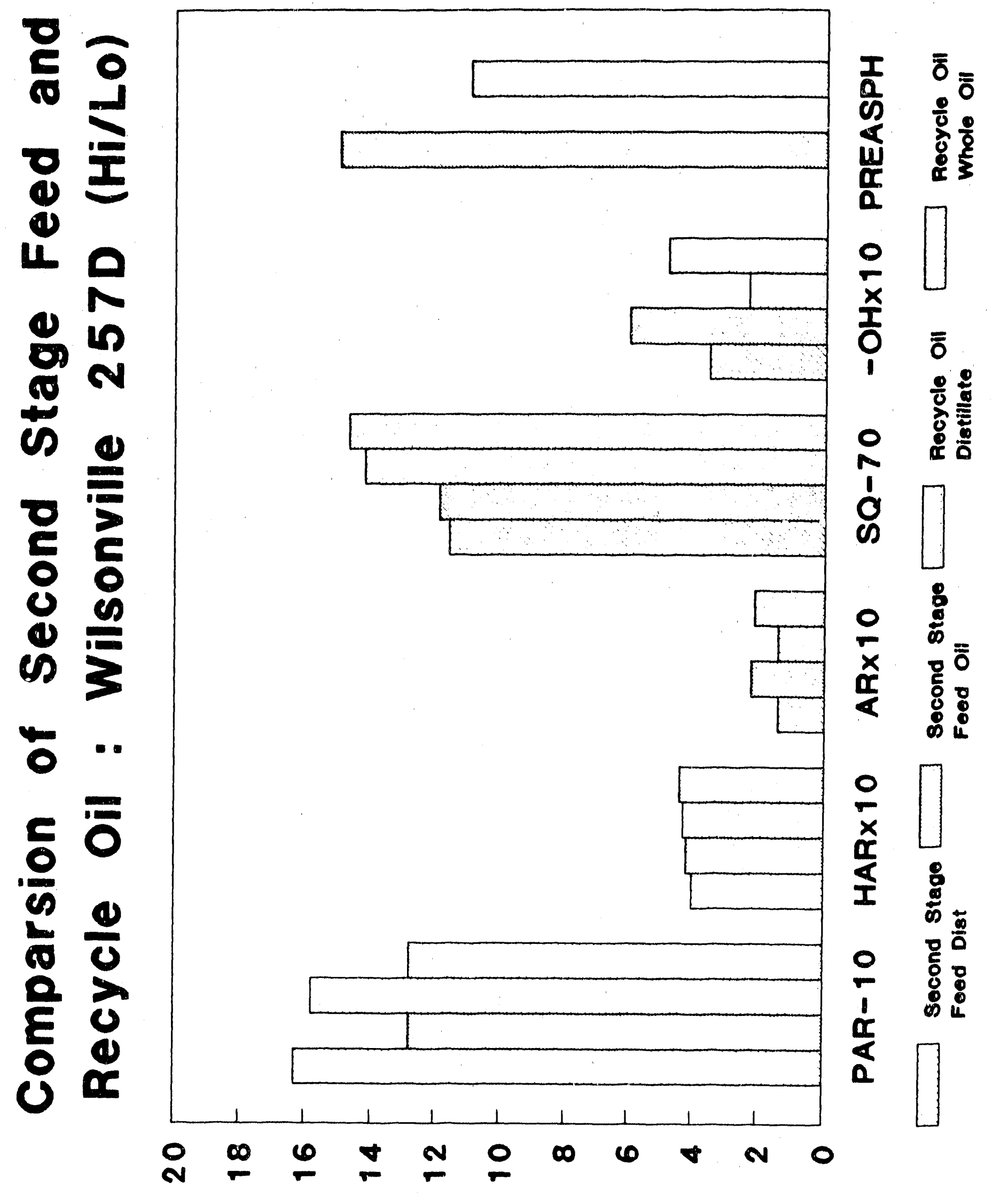




\section{WILSONVILLE CC/ITSL}

RUN 257G

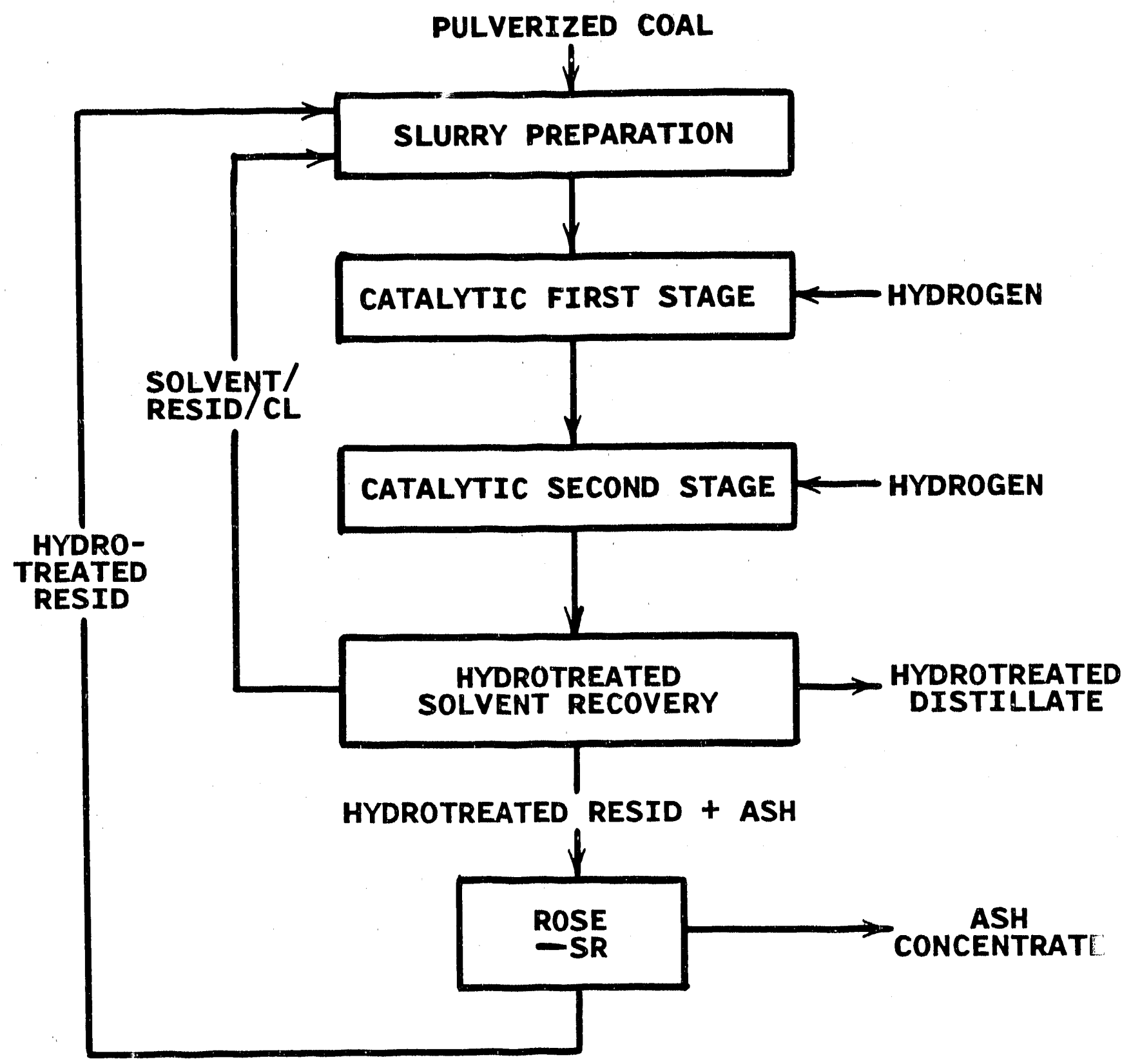




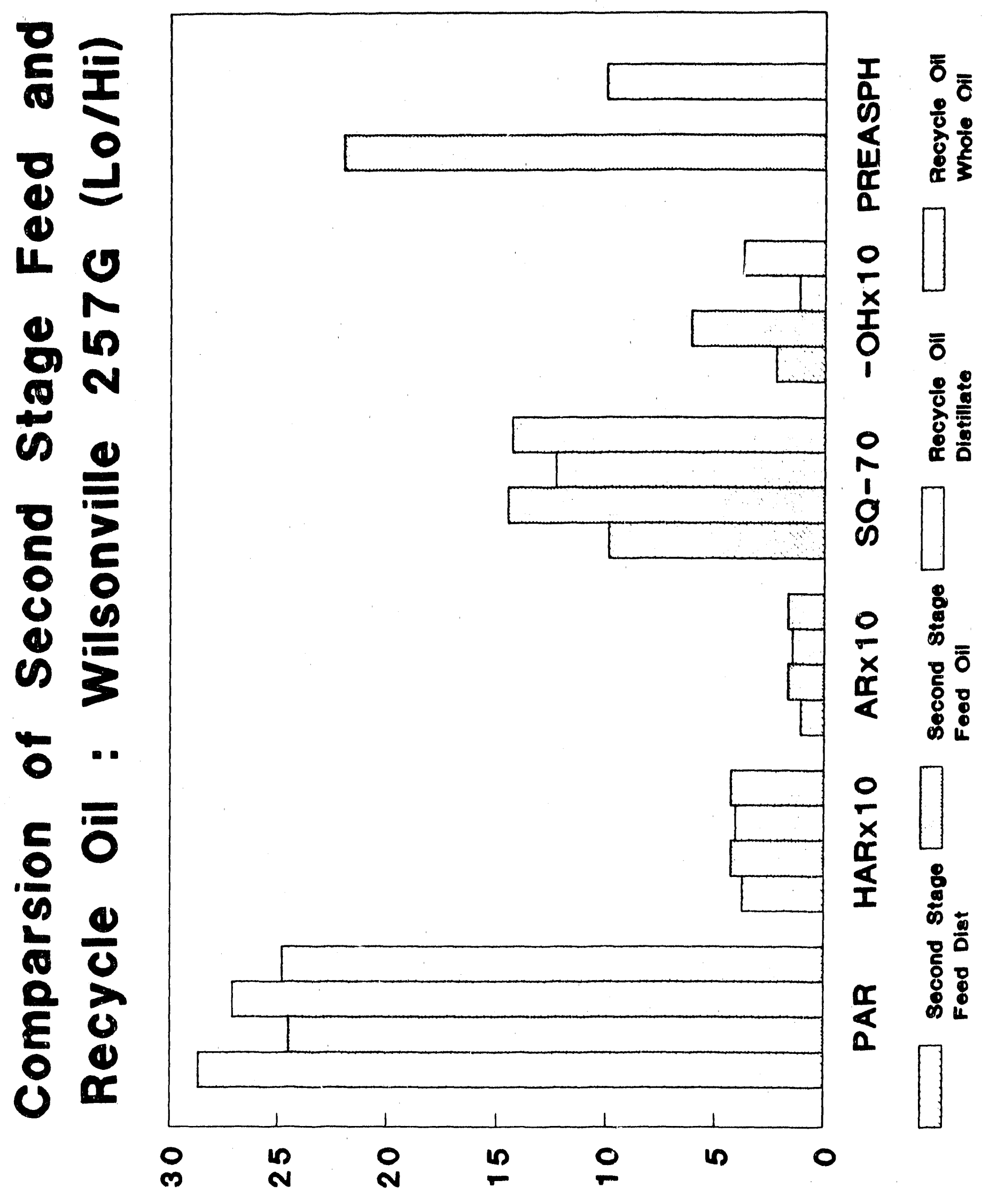




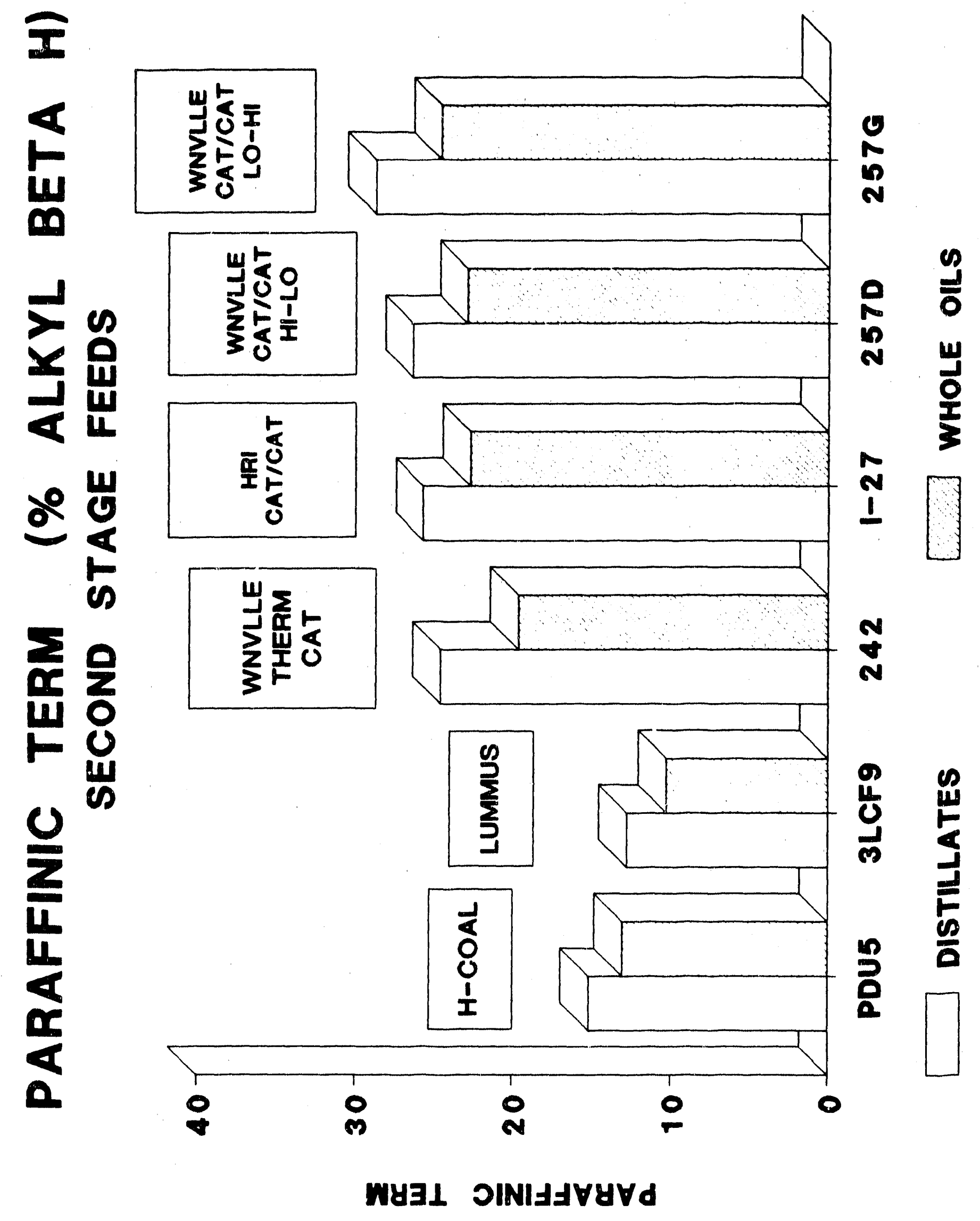




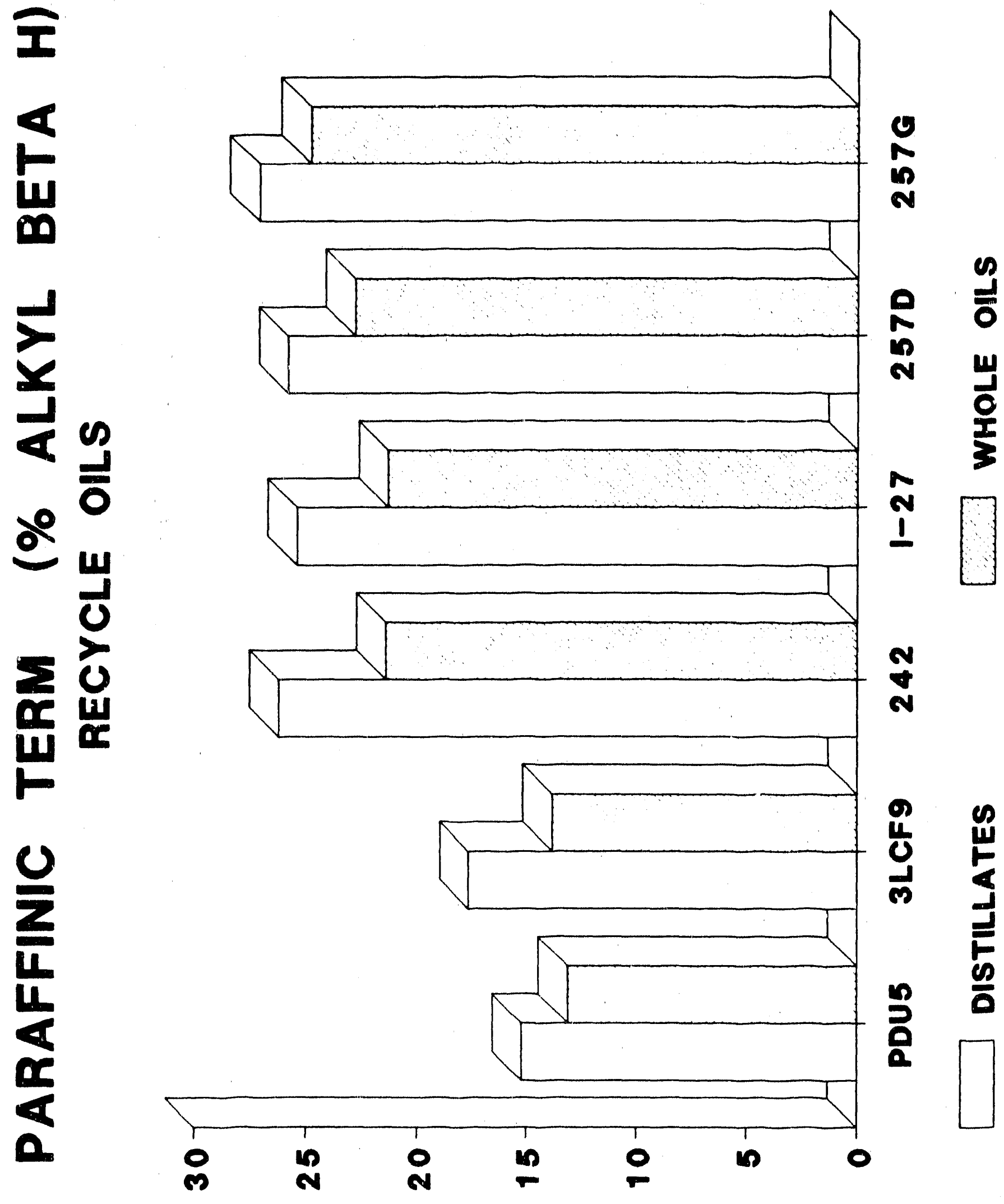

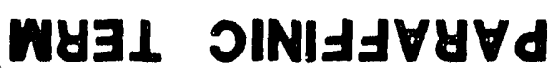




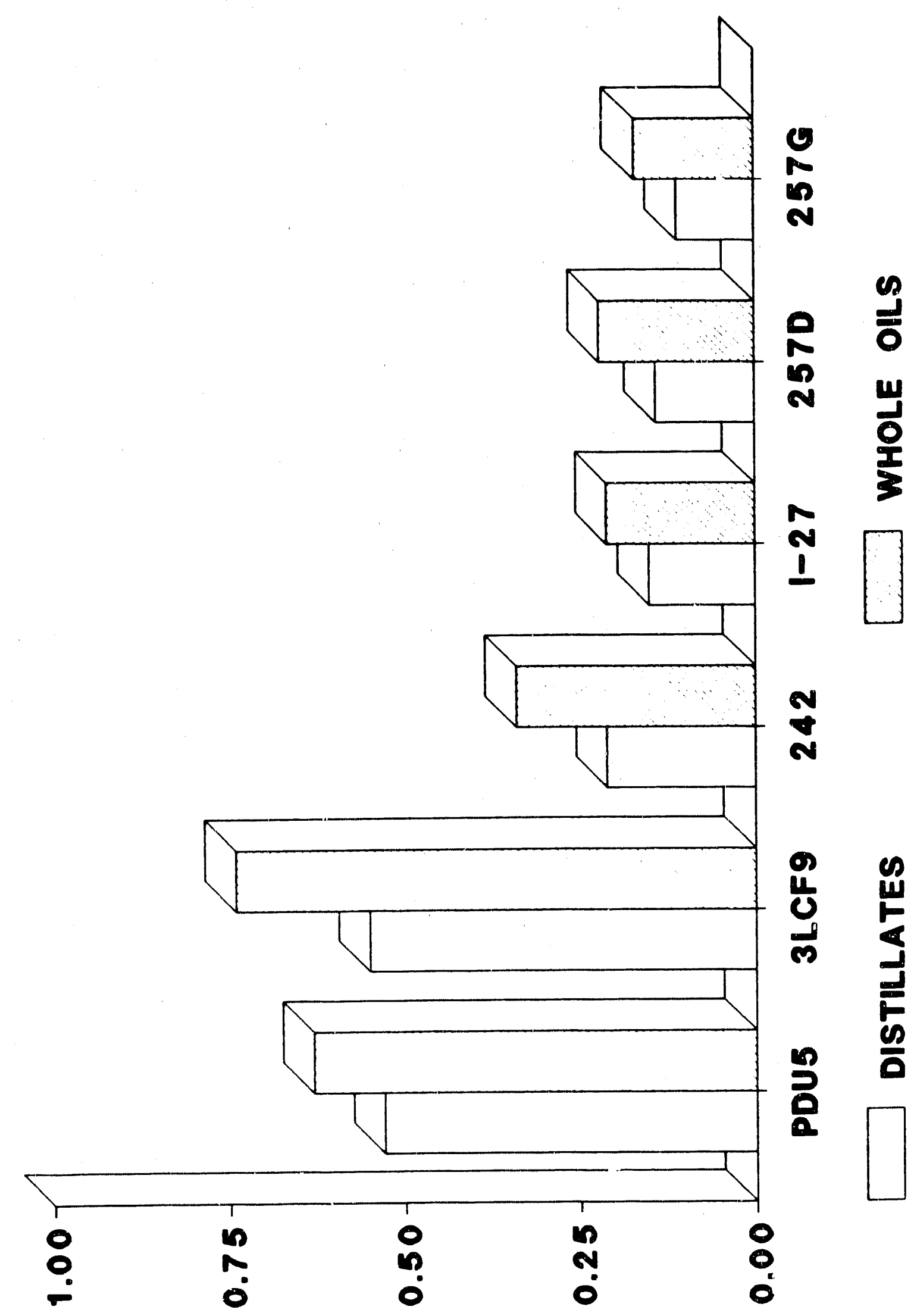

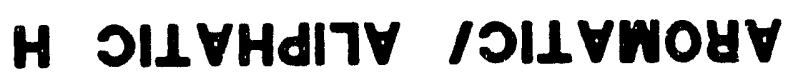

$$
-103 \text { - }
$$



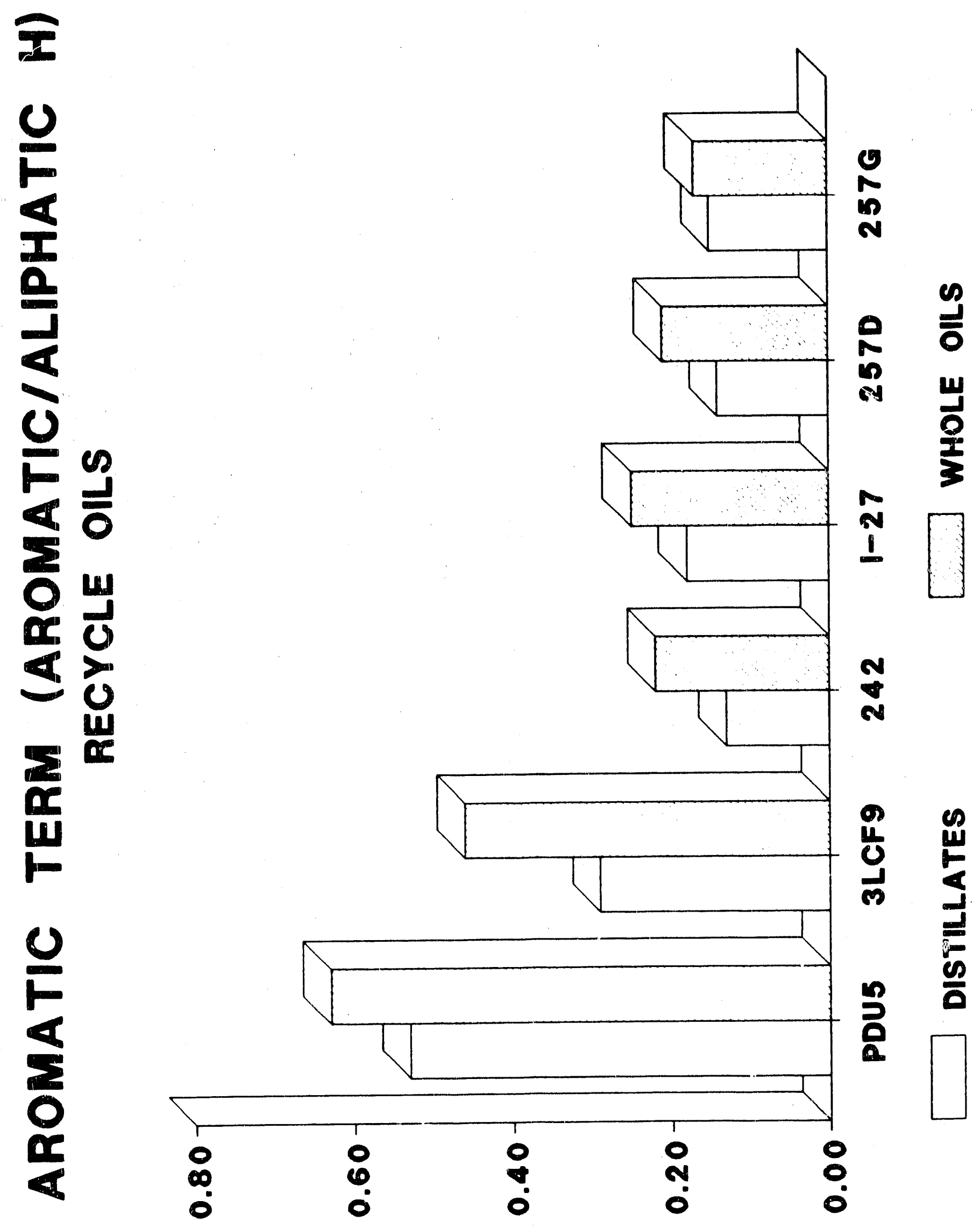

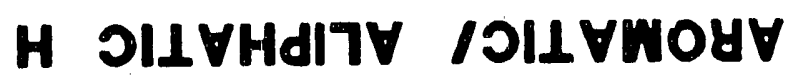



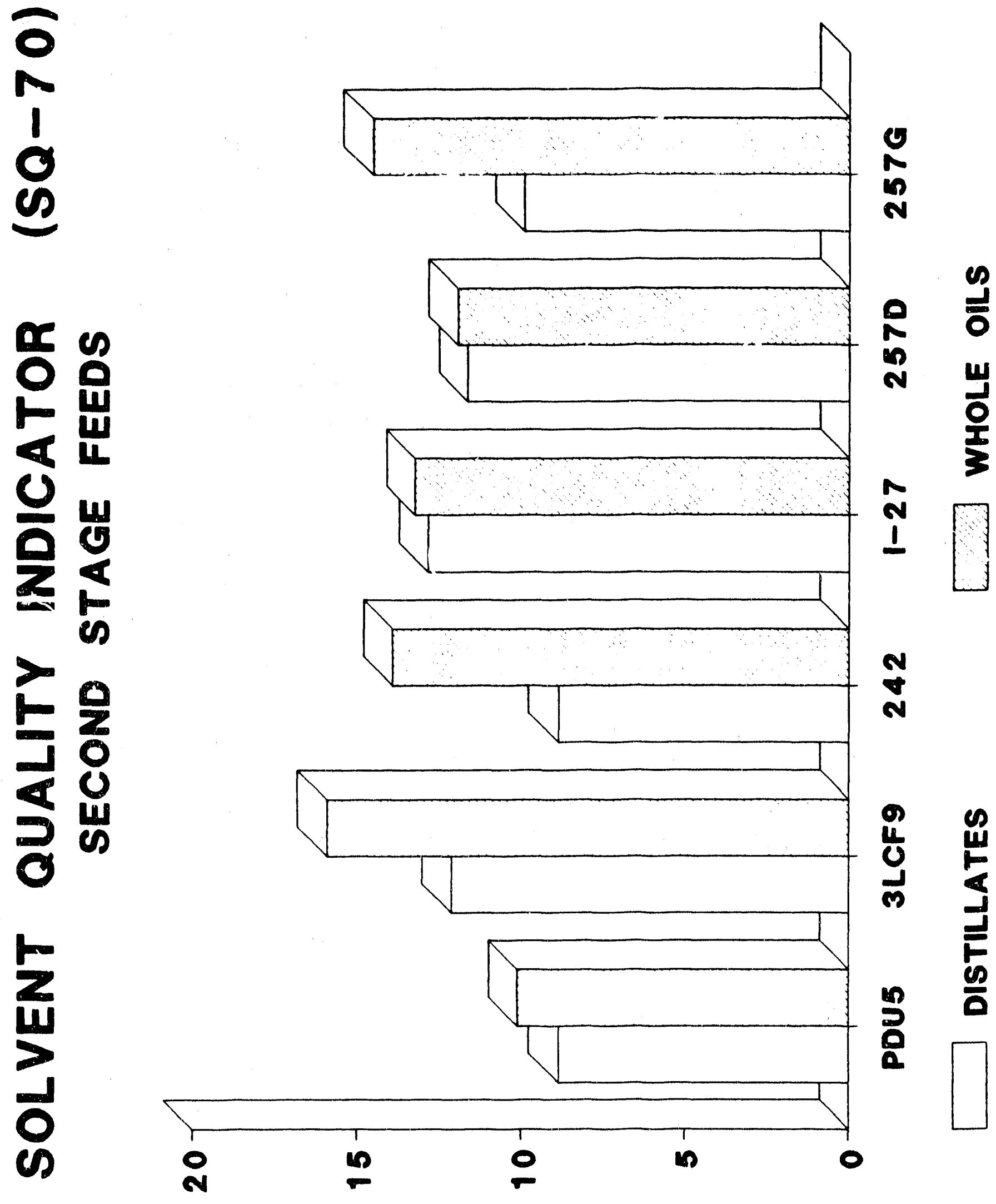

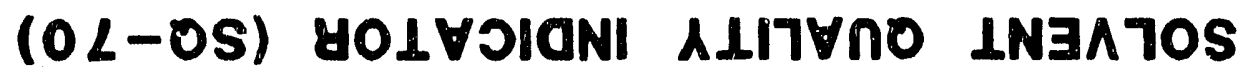




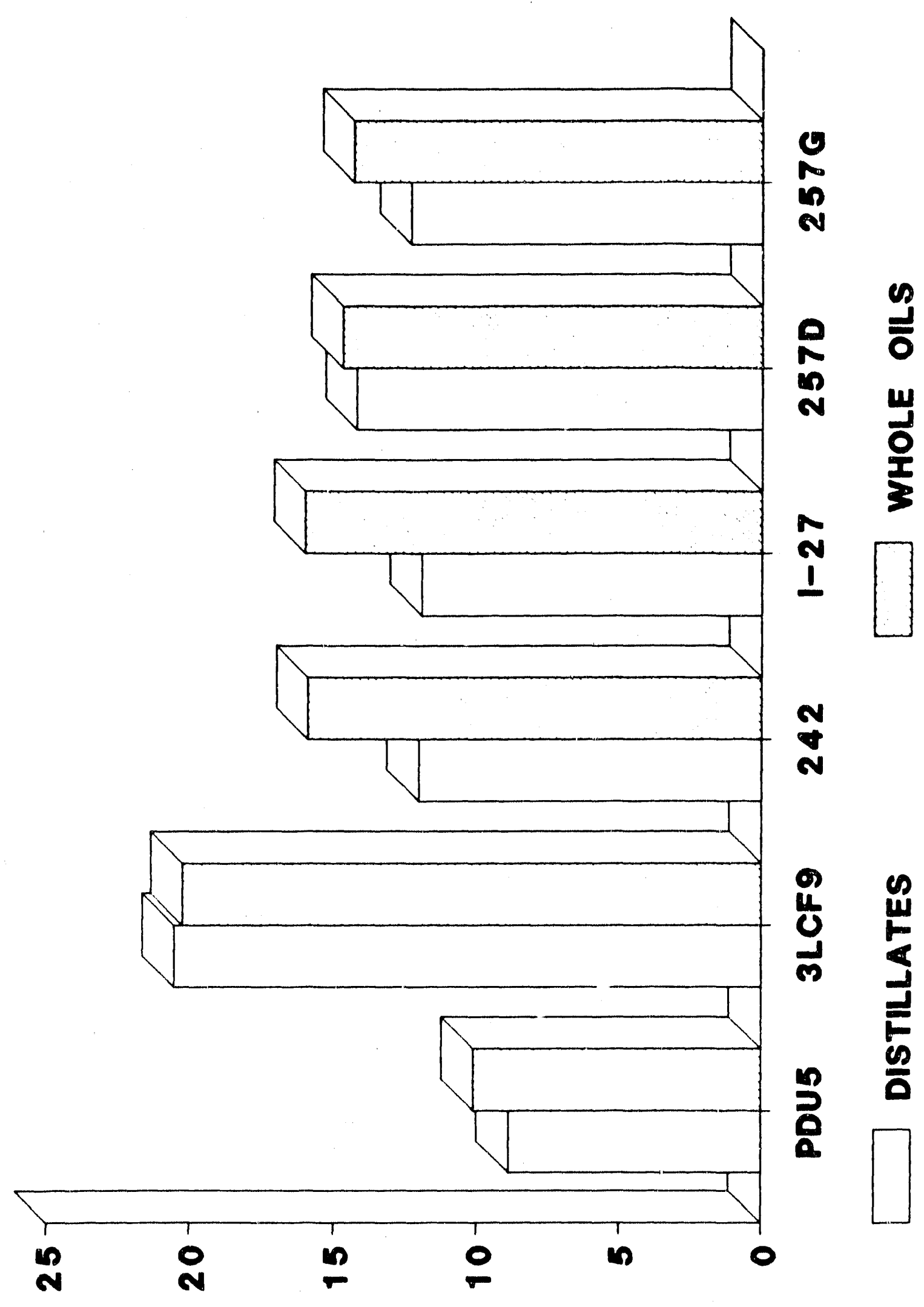

(OL-OS) YOLVJIaNI ALITZRO LNaATOS 

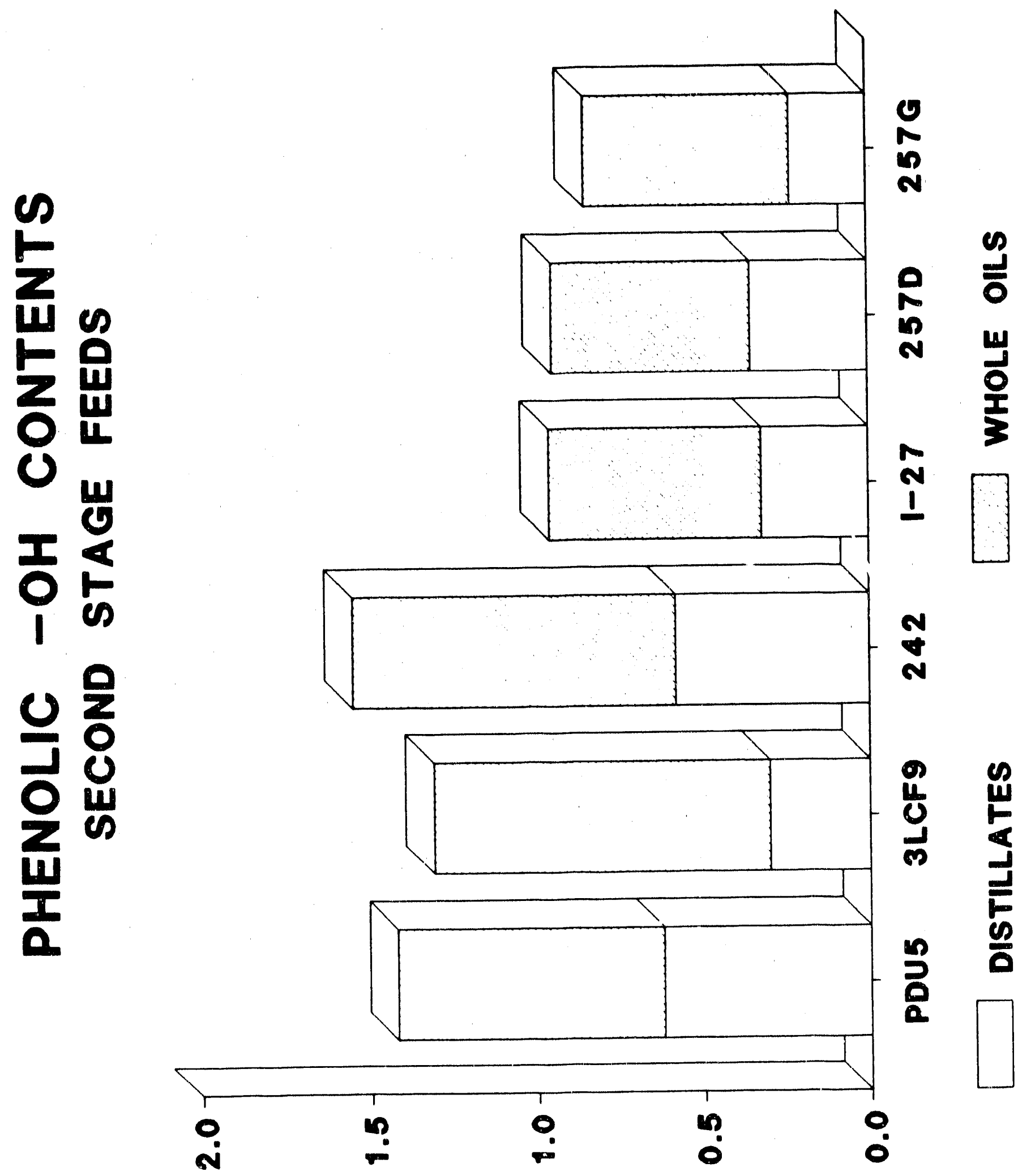

(6/bow) HO- Ol7ONBHd 

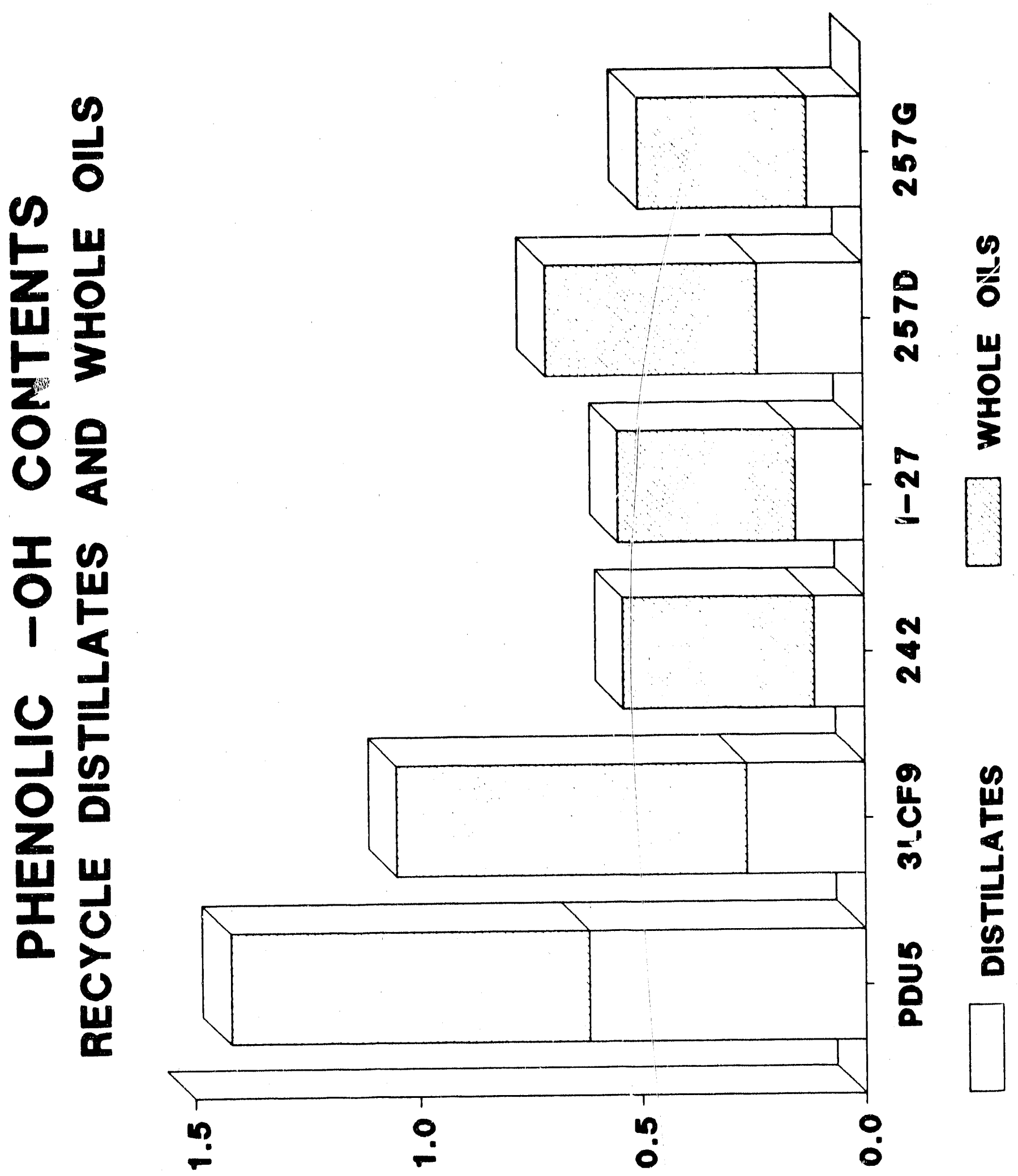

(6/bow) HO- OI7ONaHd 

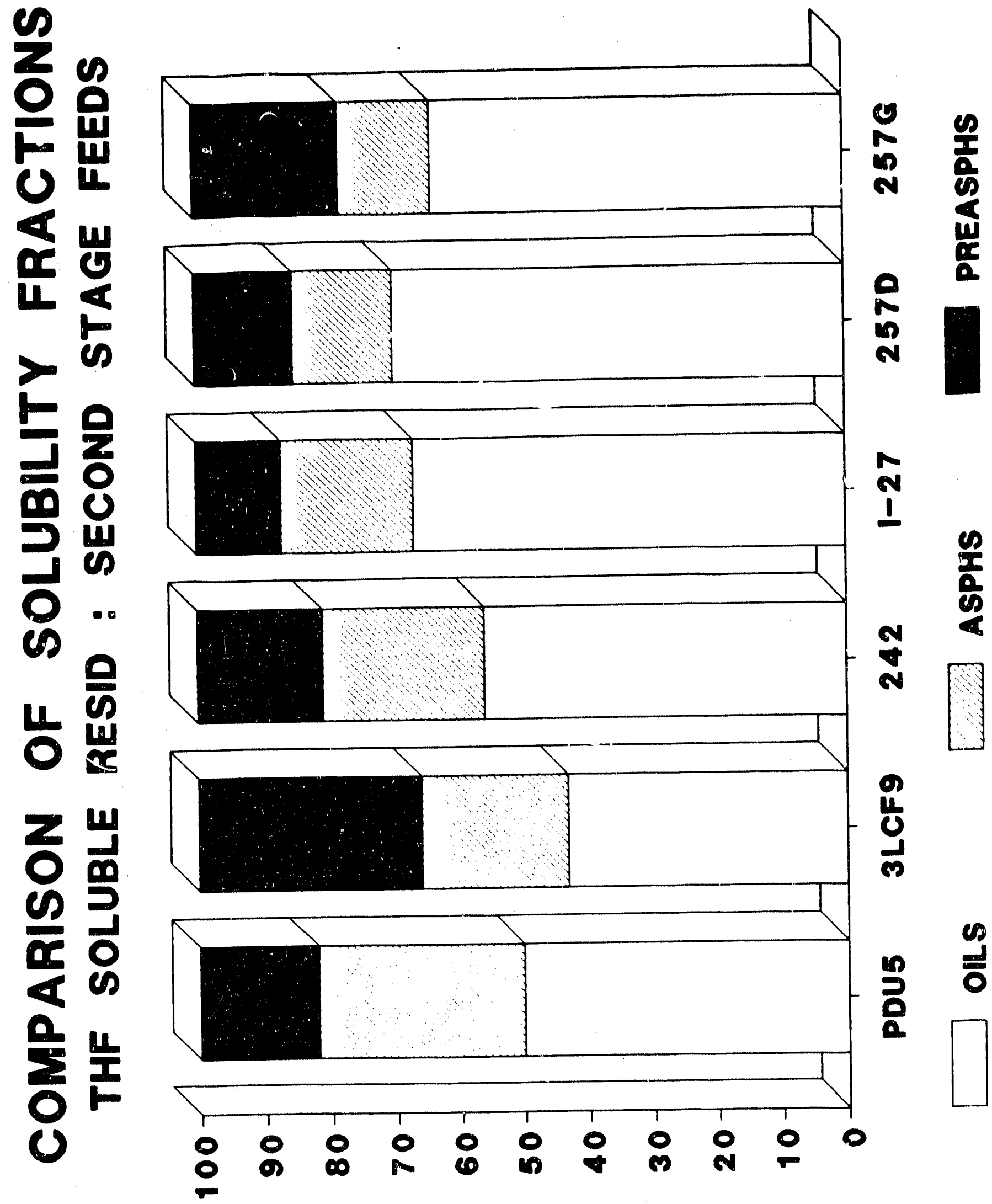

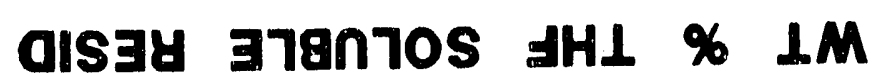




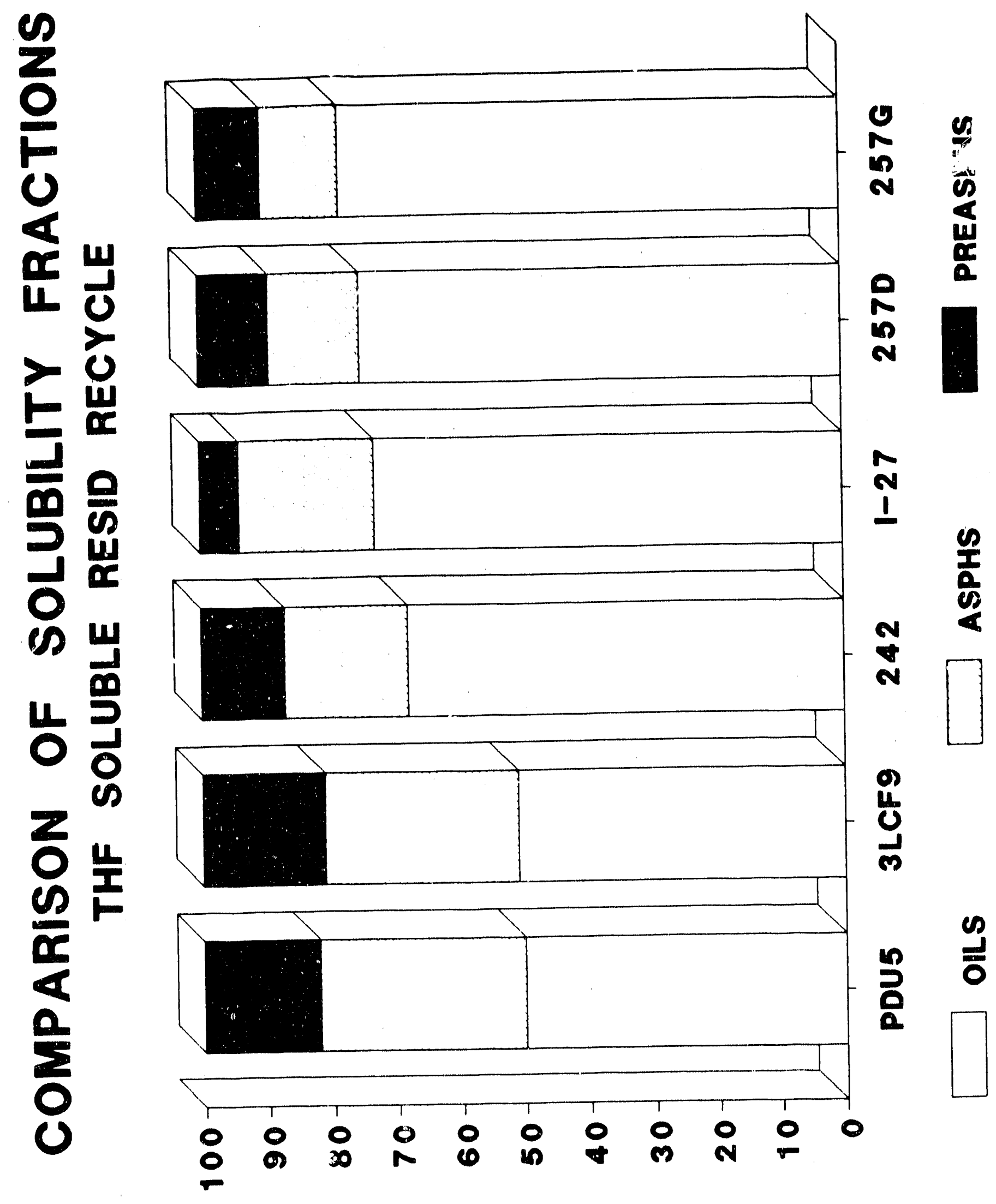

als38 3า8กาoS $\mathrm{HH} \perp$ \% $\perp M$ 

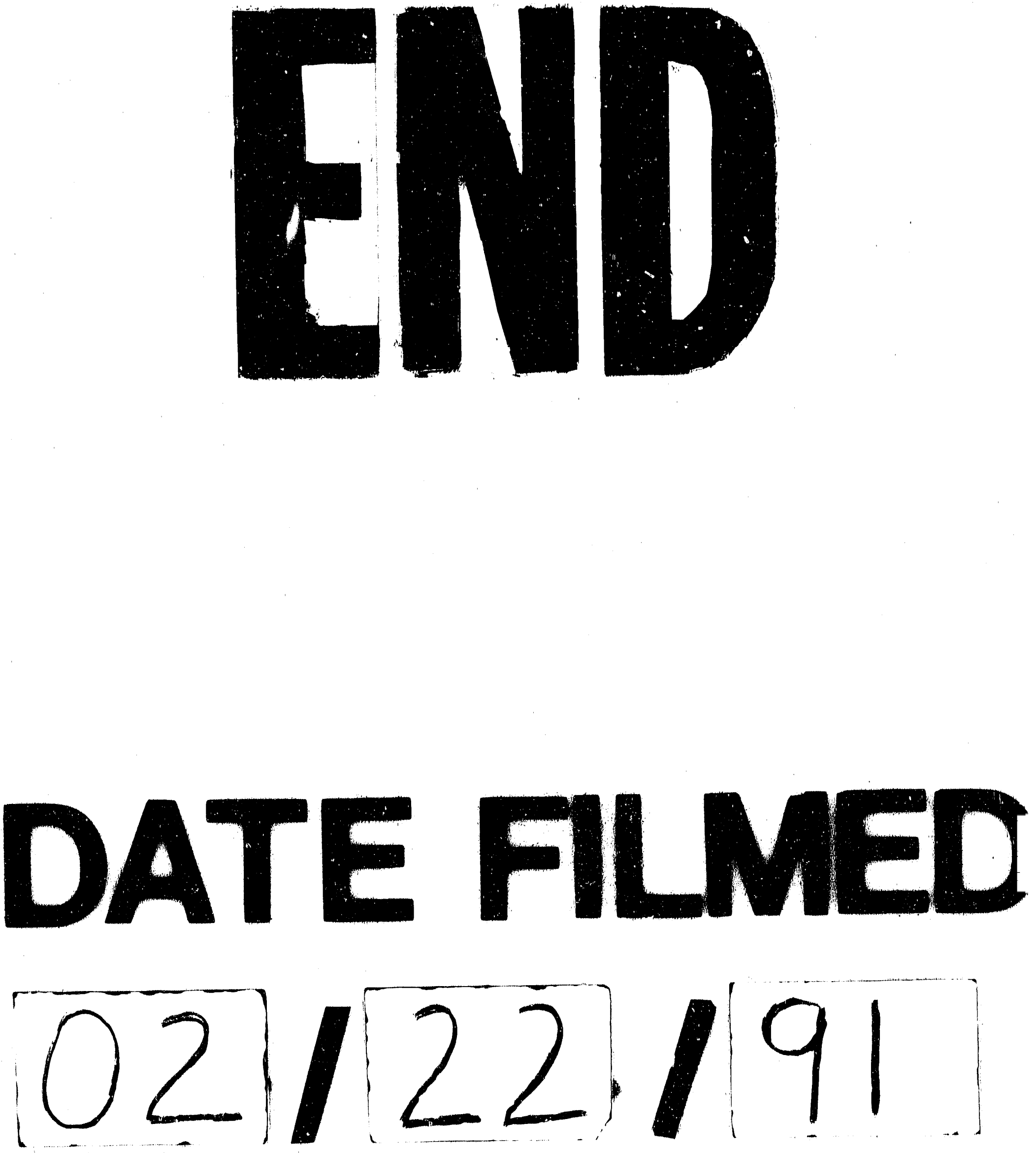
